University of Louisville

ThinkIR: The University of Louisville's Institutional Repository

$10-1945$

\title{
Surface impregnation of wood : II. gaseous impregnation of wood : III. investigations on submarine decking: IV. investigation of marine adhesives.
}

Otto J. Mileti

University of Louisville

Follow this and additional works at: https://ir.library.louisville.edu/etd

Part of the Chemical Engineering Commons

\section{Recommended Citation}

Mileti, Otto J., "Surface impregnation of wood : II. gaseous impregnation of wood : III. investigations on submarine decking : IV. investigation of marine adhesives." (1945). Electronic Theses and Dissertations. Paper 2016.

https://doi.org/10.18297/etd/2016

This Master's Thesis is brought to you for free and open access by ThinkIR: The University of Louisville's Institutional Repository. It has been accepted for inclusion in Electronic Theses and Dissertations by an authorized administrator of ThinkIR: The University of Louisville's Institutional Repository. This title appears here courtesy of the author, who has retained all other copyrights. For more information, please contact thinkir@louisville.edu. 
DTVXULITY WF LOUISVILE

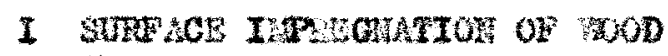
if

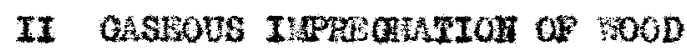

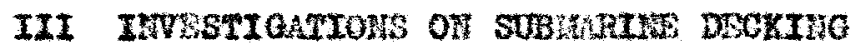

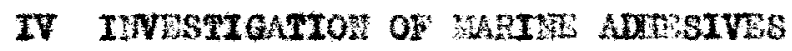

\author{
A Theas: \\ Subuttod to the Fuoulty \\ of the Credunte Sohool \\ of the Untreraity of Loulerillo \\ In Fratiel Fulf11ront \\ of tho Rogus rowants \\ for the Degroo of
}

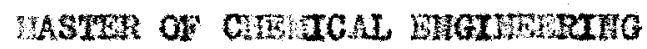

Dapartwent of Chorioal Bngtineorine

Dy

Otto J. Hets

1945 


\section{UNIVERSITY}

LIBRARIES

This PDF document is a scanned copy of a paper manuscript housed in the University of Louisville (UofL) Libraries. The quality of this reproduction is greatly dependent upon the condition of the original paper copy. Indistinct print and poor quality illustrations are a direct reflection of the quality of materials that are available for scanning. The UofL Libraries greatly appreciates any better copies that can be made available for replacement scans. 


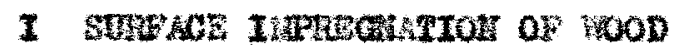

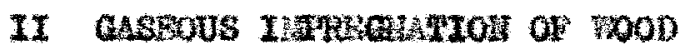

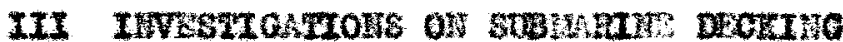

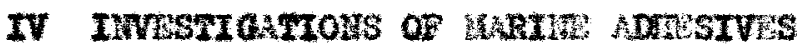

otte J. Mteth

Approwol by the Funating cotat tbeo.

Mrootor Gordon C. Williams

R. C. Ernst

W. R. Barnes

Ootobor. 1945 
InDe of comprors

Page

Llat of Tabled $\ldots \ldots \ldots \ldots$

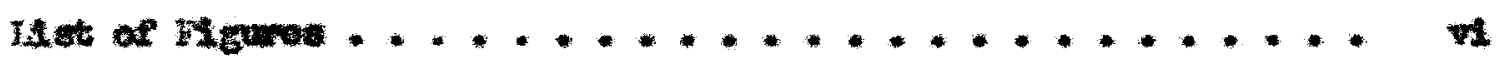

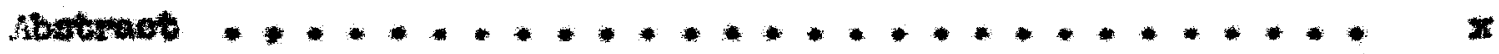

1. Surfoes Inxogrution of Mod

Introdustima $\ldots \ldots \ldots+\ldots \ldots+\ldots \ldots+\ldots$

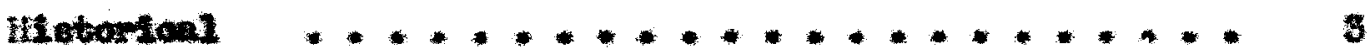

moarctiteal $\ldots \ldots \ldots+\ldots \ldots \ldots$

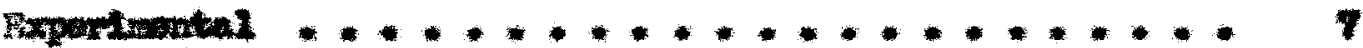

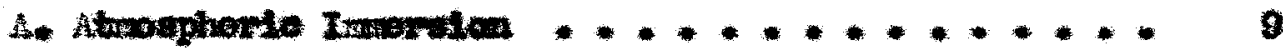

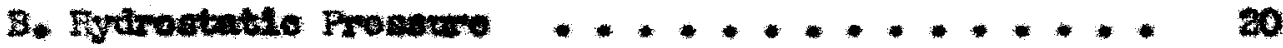

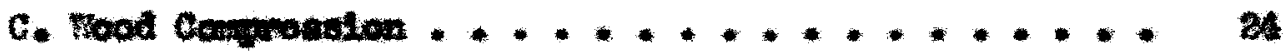

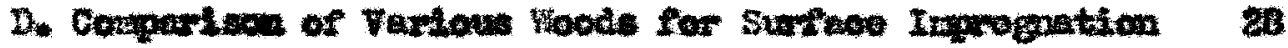

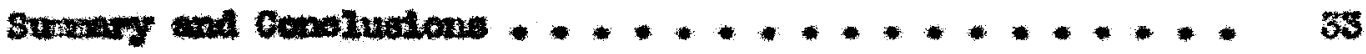

II. Casaous Ingwopation of Hoad

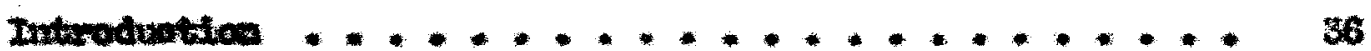

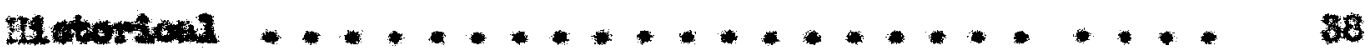

Teantioal $\ldots \ldots \ldots \ldots$

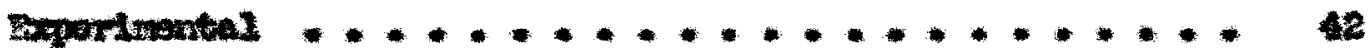

surrary $\ldots \ldots \ldots+\ldots \ldots+\ldots \ldots+\ldots$

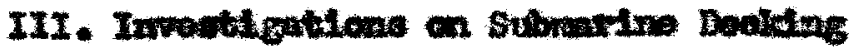

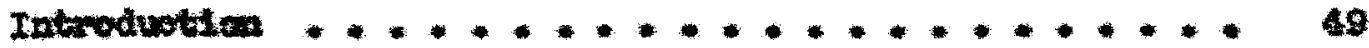

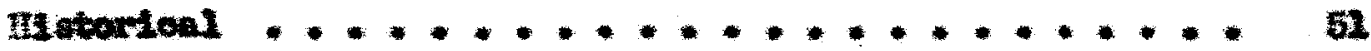

Thoorettoal ............................ 5s 


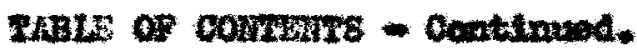

Page

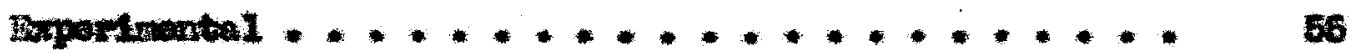

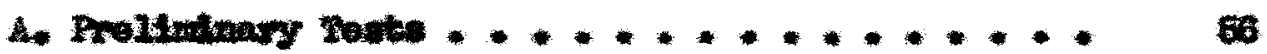

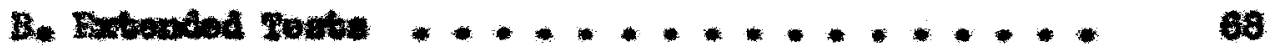

sumat +.............................

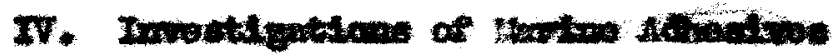

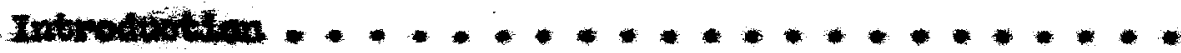

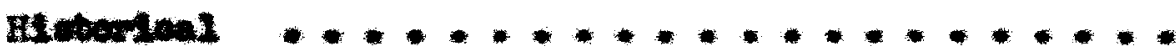

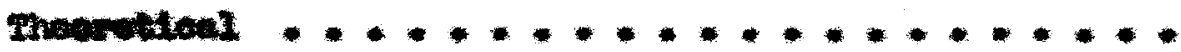

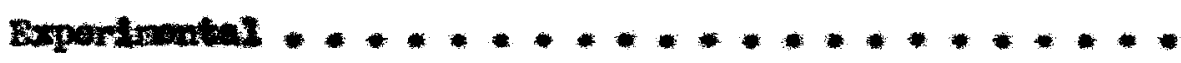
\$2

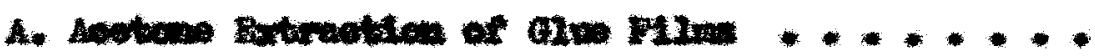

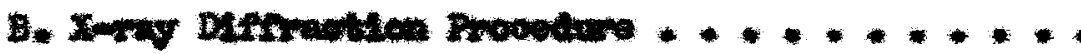

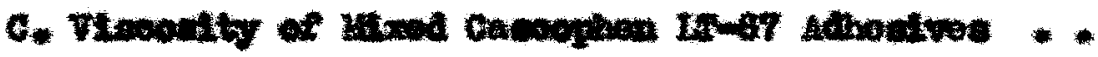
238

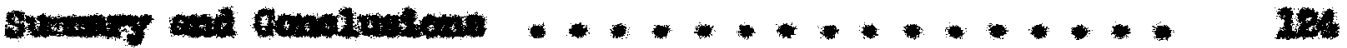

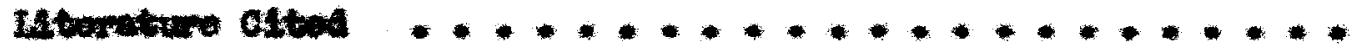
167

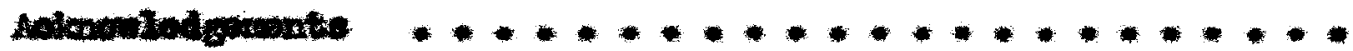
129

Nke $\ldots \ldots \ldots \ldots \ldots \ldots \ldots$ 181 
Itsp ov abtas

2ab?

242

Past

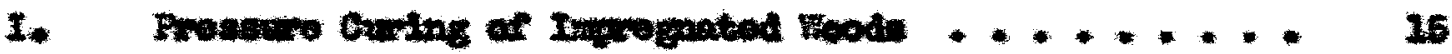

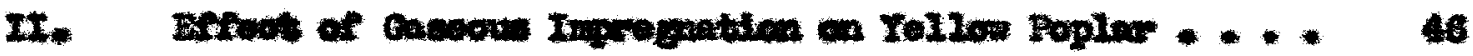

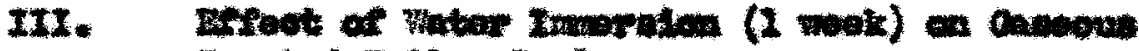

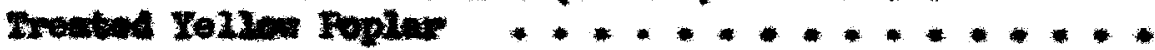

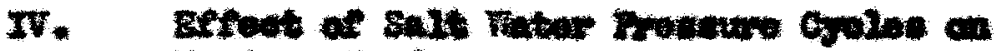

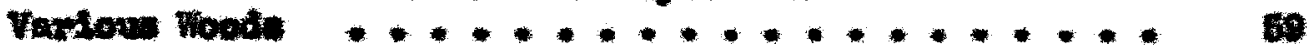

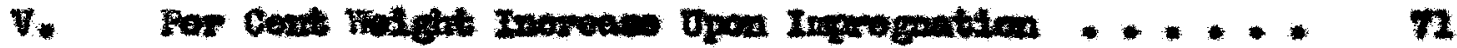

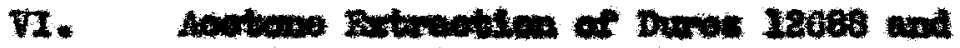

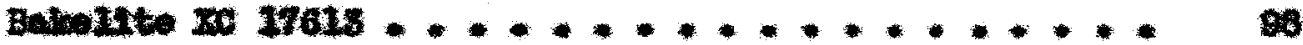

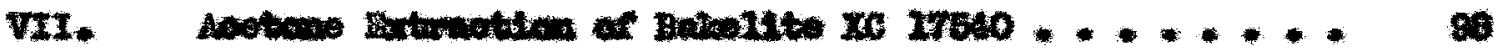

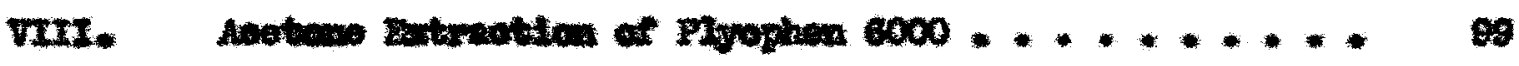

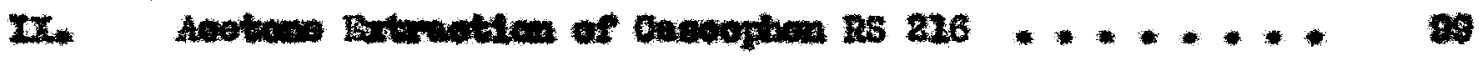

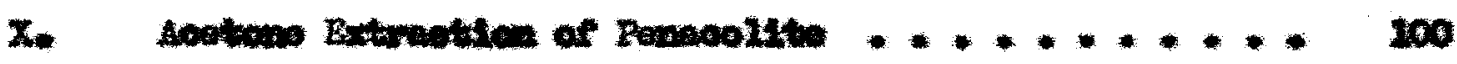

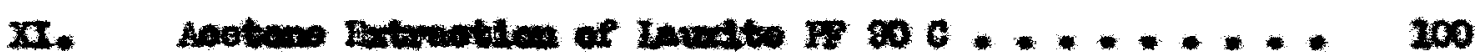

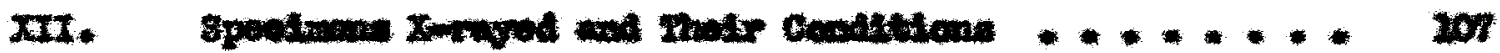

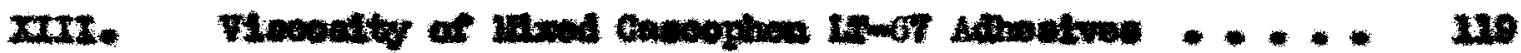


LISP on FTavwes

Elare

atto

Pese

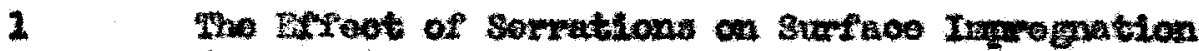

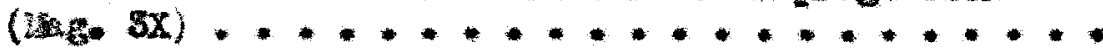

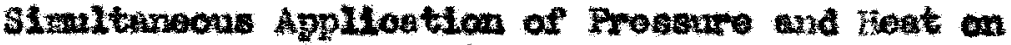

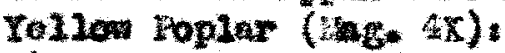

a) D. Hev. Imprognated:

b) Wetor sorkod .......

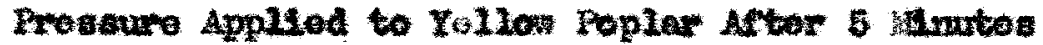
Feating (thg. 4X):

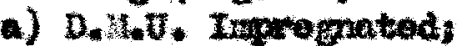
b) vatar soatrad

Frogence Applled to Yellow Poplar After 10 ismubea Ieating (ime: 4X):

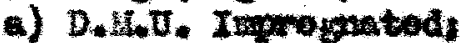

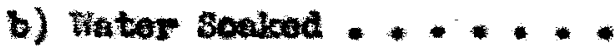

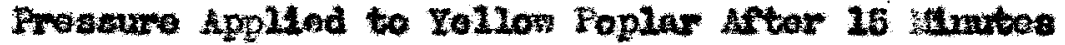

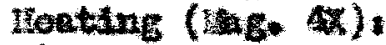
a) D.
b) Naber Soakod.

19

6

Crose seothen of

a) Orlginaly b) Aftor 9 salt Wator Promburo Gyolos.

Croas Sootion of Tallow Ptino (1) Ex).

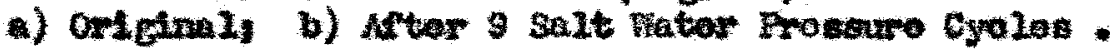

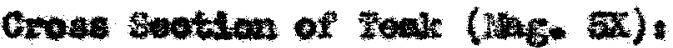

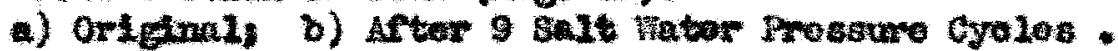

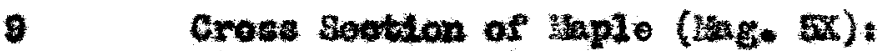

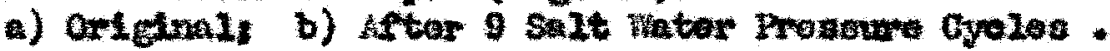

10 Croos sootian of thagany (Fag. EX):

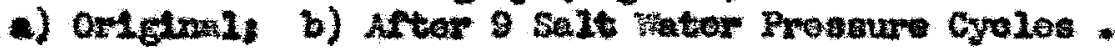

11 Croes Soctura of Donglas IIr (MG. DX):

a) orlginal, b) After salt viater prosaure gyolos.

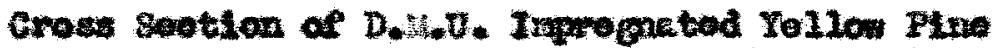

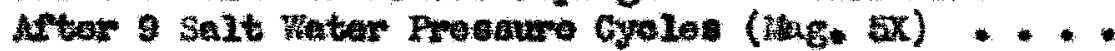

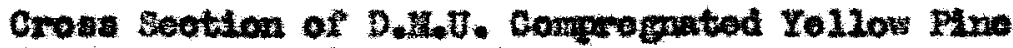

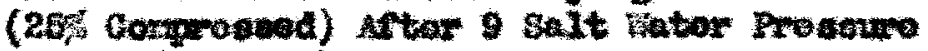

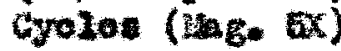

Grosu sootion of D.

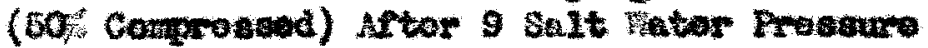
Gyozoe (itge 5x) 


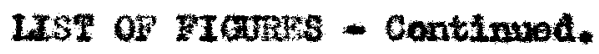

10use

Istie

Pare

I5 Weldht Inowsise food During Prosaure cyelos in

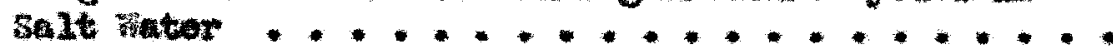

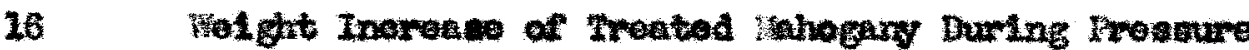
Goles in salt meter $\ldots \ldots \ldots$

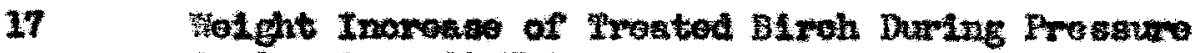

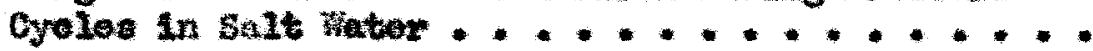

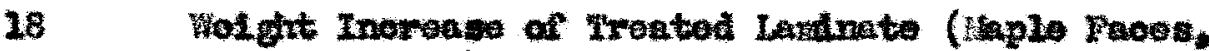
thagegry Como) During Prossuro Cyalos in salt

water $\ldots \ldots \ldots+\ldots . \ldots \ldots$

29 The nfreot of Speotes on Sealor Imprognated Toods ..................

20 The sffect of sposios on welght Inoroase af Coppor

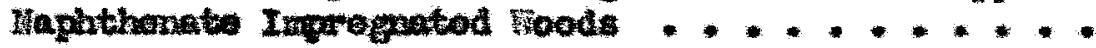

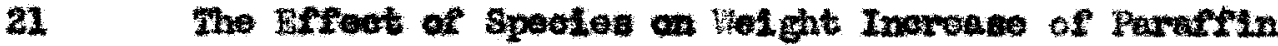

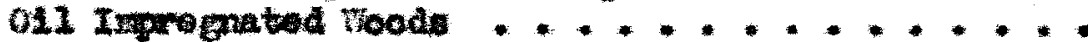

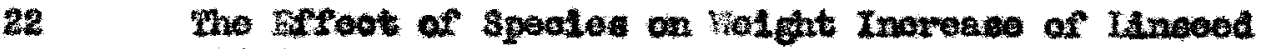

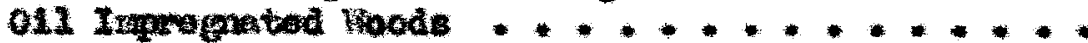

Tho Effeet of spoties on Fetght Inoroase of mung on

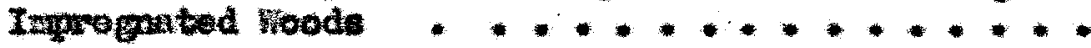

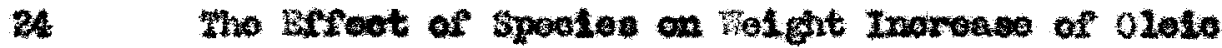
Aold Inprograted Foods ..................

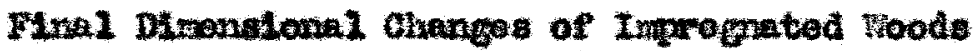

After Prosenre Cyoles in salt rabor .........

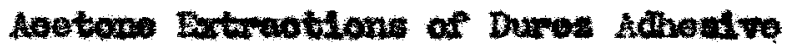

(12088 Realn, 12809 Hardenor) $\ldots \ldots \ldots$ 


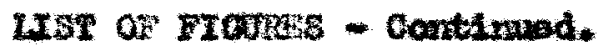

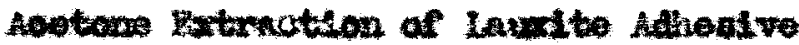

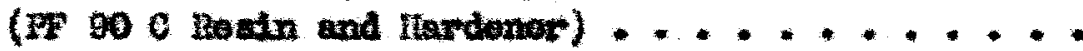

$x$ may Burnation Pattern of Hnowred Cuseoplen

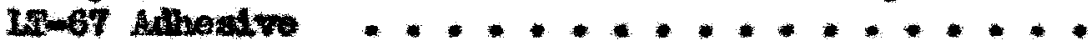

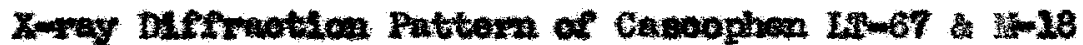
Allodve (Unoured) $\ldots \ldots \ldots+\ldots \ldots+\ldots+\ldots$

X-roy Difrmation Fatborn (Poedor thod) of

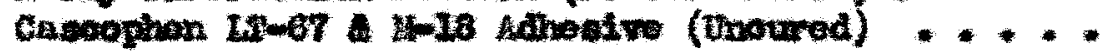

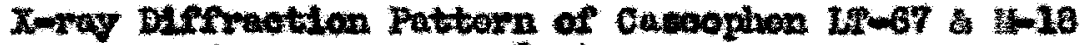

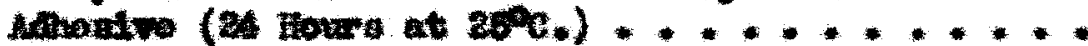

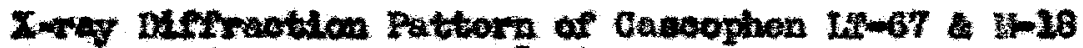

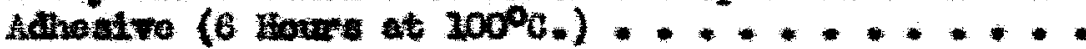

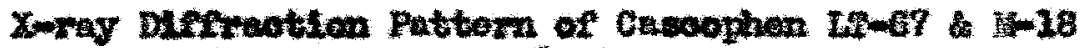

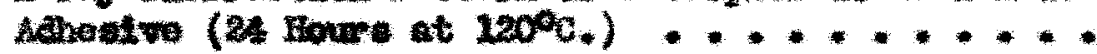

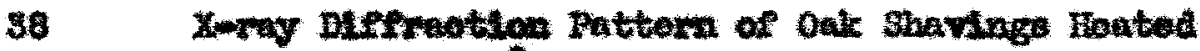

24 Houre at $120^{\circ} \mathrm{c} . \ldots \ldots \ldots$

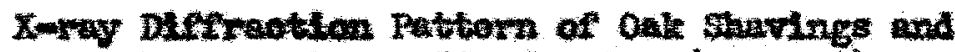

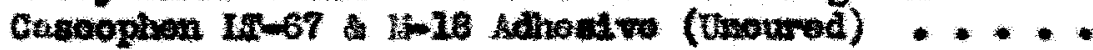

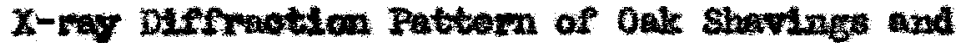

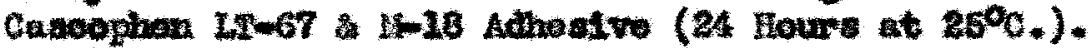

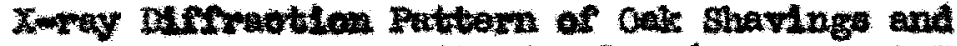

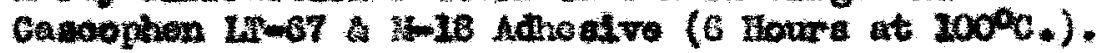

X-ry Dirmation Pattern of Oak shavings and

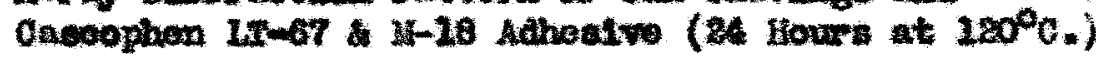

x-ray Difrabton Fattorn of $\alpha$ - delluloso $\ldots$

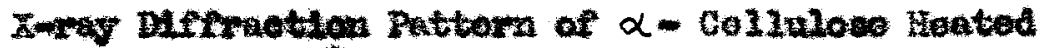
24 lours at 120\% $0^{\circ} \ldots \ldots \ldots$ 
LIg of MaURs - continuod.

ILne

46 X-ray Dufrection Pattorn of $\alpha-$ - Cellulose and

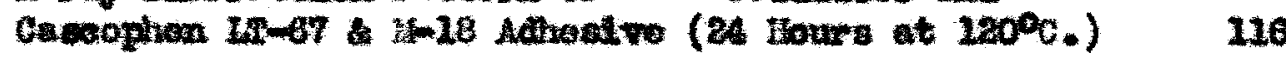

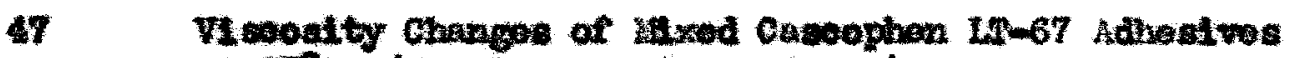

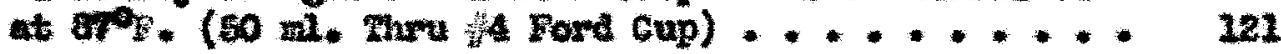

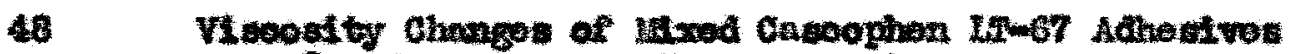

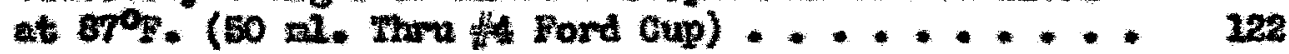


$A B S D A C$ 
This thess prosents results on mothode usod to produce a hixd surfacod wood produot. The wothods involve the parting of tho wood Ilbers on the awfave by a spolal serrating tool. followod by surfaco Improgation and final ourlag. Fhe sarrations on tho nood ariaco groduoe en artiflolal grain upon ourlng.

A peollininary investigation was to lmprowa tho rot-

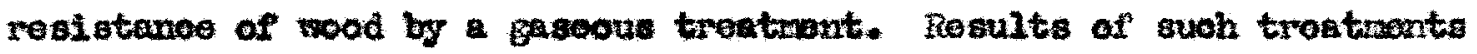
ghow bore limtod aveoes wth formaldohydo on yollow poplas and warrant Purther study.

An Invottigation was mado to find a subetitute for toak rood

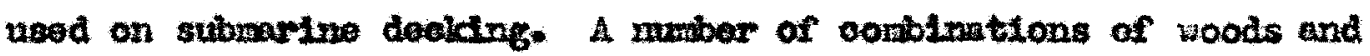
Inprogating agente were proparod and tosted under stmulated oooan conditions. The roaults of those tests indionte that a raplomahogany lardnate, whe breatod wh tho propor agont, w11 compare favorably with toak.

The optinm ourling conditions of several phenollo resin adhealves are preaented as doterninod by an acotono extracting prooodure. The reaulte are pronented for an attangt to roplace the aostono oxtration procodure by an xway alffraction method. X-ray diffraction pattorme are prosented of wood, $d$-0ellwloso, and a phomollo adhoalvo. Whe viseonty oharactistios of mixed Cescophen LT-67 plinolic

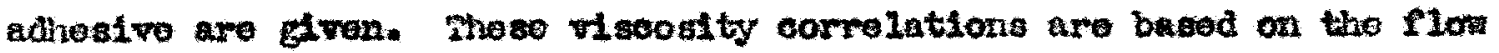
of martel through an oristoe. 


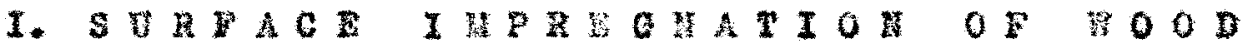

I 
Wood is ono of our woot abuudart natural mosouroos. Howover It has beon 1 int tod in 1 ts was boouso of oortain inherent proportios.

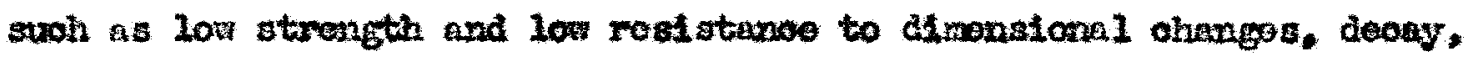
and chemionis.

It has boen found that ingreguating nood with synthotso roaine preatly lmpares the proportlos and produoos a hard, dimenstonally otablo product, with a hig compreosive strength. Suoh produots, thoud

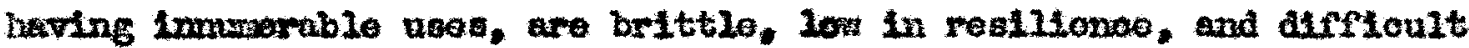
to gluo or faston.

It was thoreforo doalred to produoe a produot having a hard, danse, water repellent wufaco, rostotant to maring and grain raising. and with act core to provide the destrod reallionoe. Ihts has boen acomplishod by producing a plywood of comprobed rostn troatod fuco pllos wh an uneorpreased oore in a eingle operation. Sweh ar asserbly is ade posstble by tho plastlatskig cotion of the roetn

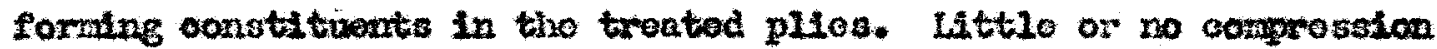
tales plow in tho dry, untreated oore.

The objoot of this resourch was to simplify this prosodure for prodwoing auch a produot by irqugnating tho aurface layere of a solld ptooe of wood and to produce tho hardoned surfoees as an Intopral part of the mood rootion. 


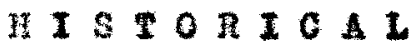




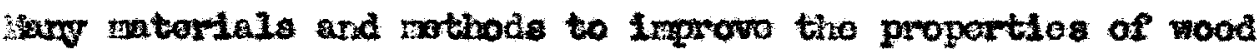

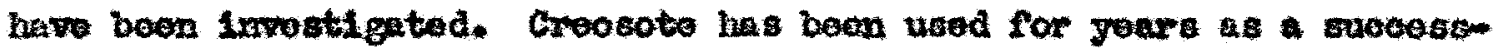
ful wood proservative and many othor abaatoals have boon found to bo toxio to cortain wood destroying organtand. llowevor not unt11 recont yoars ith tho developmont of aynthetso restins hes any defunto step beon rade to inprove wood to the oxtont of produoing a ctrong, unferm, and arable netorial whitoh opuld talos 1 to plave along alde that of plactios and atalo*

Salt solutions (1), oils, waxo (2), and nany other antorlals inavo boen found to rotard the rato of absorption of molsture in wood, thoreby cousing a tomporary roduetion in awelling and shrinkage. lator. Stara and Soborg (3) report a pormanent dooreabo in tho dimenelonal chango of wood by agnthotio realn ingrognation. Thoy (4) haw roportod a mothod of produolng oompregrated mood ublng a phonol formaldohydo typo robin and have dononstrated mary uses for vuoh produst.

The Dulont de Noroura Corpany (5) has produoed a dimmatonalIy stable wood by inpregrating it with drothylolurea in a rothod sting lar to that of tint phenol-formaldohydo roain.

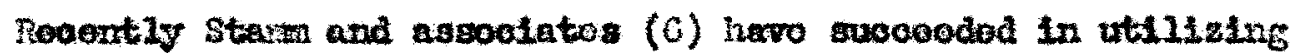
the resin proportios of tho 24 gun to produce a hoat-otabilized oomprossod wood. Tho rood is comprosced undor suoh oonditutons thet vill

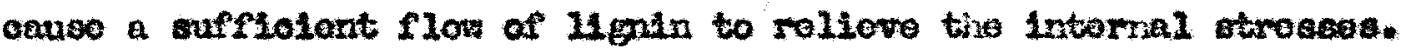
The produst is not to stablo as oomprognated wood, but it doos posaows sovoral suporior qualitios lnoluding a rotably groater impot strength. Ialley and aseoolates (7) have presomtod data ooxprating the rolative marts of varlous rosin troatod wood products. 


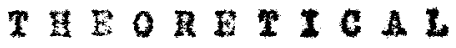




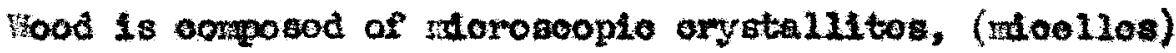
IIrikod togothar to form oollo, in the ahage of hollow spindlomahad, ologed and tubes. Sino the raterial oompoing the ooll walls is

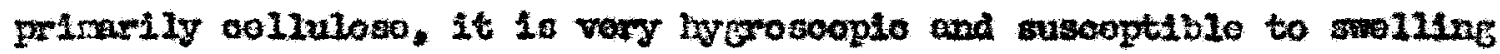
with ation.

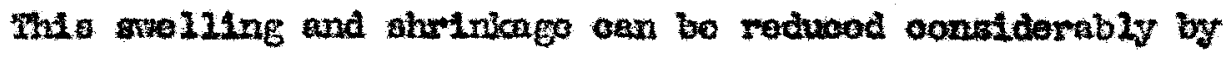
inprogation with a synthotto resin. However sinec the coll wall is the If groseopto raterial, it is not suffiolent to diffuse the rosin into the eavitios, for this would produce only a number of hard non-

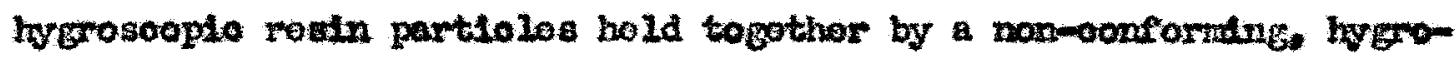

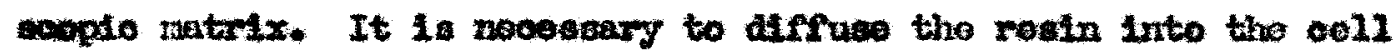
walls whore it oan atbor form bond with tho wood fibors and theroby 011ndinato the hyoseoplty of the 3xioulles, or completely bind the ontire structaro. The panotration of those oell walls roquires a

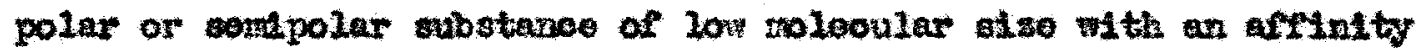
for collalose and $21 \mathrm{galn}$ moloculos. Suoh a aubstance has been found In tho ayntinotle reain of the phomol formidehyde type on whioh tho condonsation has boon errosiod at on oarly btago.

Such a roatn nay bo wae for surface impogation; howevor unilise total ingregnetion, the penotration mat be wholly fron the fave of the wood alnoe it is dosinod to harden just the surfaco. The auffece hardontrif could be reallsod by enting the produot undor

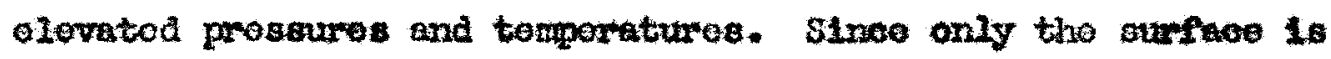
troatod, upon applyling hoat and prosauro the plastlelatris atoton of tho resin should oause the surfavo to bo oompressed and hardonod. The untreatod core should rotain its orlfinal sof toos and roblilonoo. 


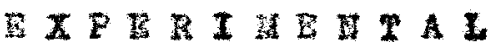


This work is a ocntinution of the prolindmary investigations of Sara (8) to coteratio a rothod of surface lmprognating wood. In his invostigation saora found that sorrating or soparating tho wood flboro the surece groatiy aldod rosin ponotration, and upon ouring.

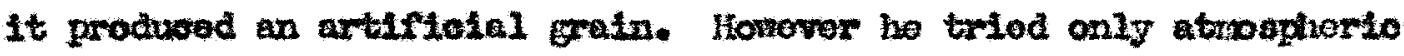
soliting of the mood in the resin solution and falled to got a untorniy Inqueguated arrfaoe.

In this investigation throo wothods of Irpreguation woro triod

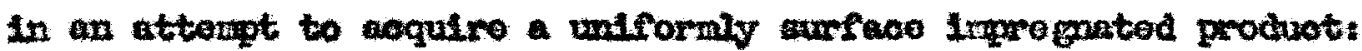

1) Atroapherio Imoration 1.0., inworaing tho suplo in the rosin solution for a fiven longth of tro at atrospheric prossure.

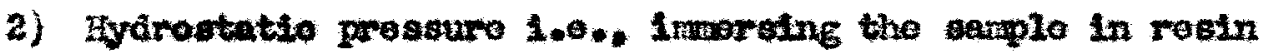
eolution for a given length of thro under grossure.

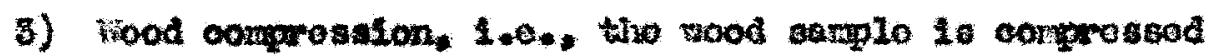
and roloasod in posin solution.

A comparieon of varlous rosins and difforent woods was also nado viting tho 3 nothods.

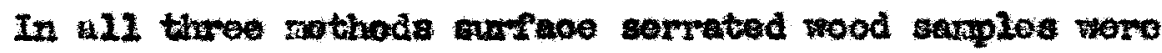
tested. Thoev nemrationo wero nado in the fibor arreotion on both facos by pasalng tho bamplas botween two rollors onoh having a sertos

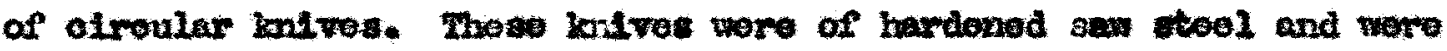
ground to fine odigo. 


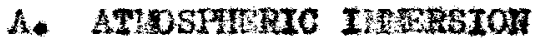

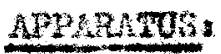

Laboratory aleotrle owens wore veod ab lin ariers. manually oporated hydraulio pross, mate th the Charles E. Frandes Compary. was uaed to ouro the troatod ramplos. The pross had oloctrioally botod platens ountrollod by themotats and was ongable of standing a so ton total mogaro.

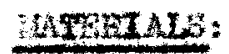

Fintehod yellos popla $(6 \times 3.5 \times .9$ inohes $)$ having $y$ shaped serrations 0.08 inohes apart and 1/16 inoh doop rowing tho longth of the wood mos nsod as tost spootums.

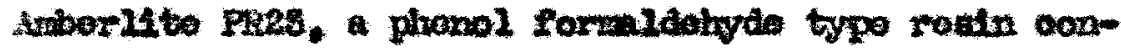
talnize 30 por oent solids in a mator soluthon, vas used firet as

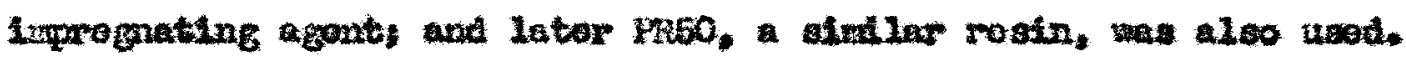

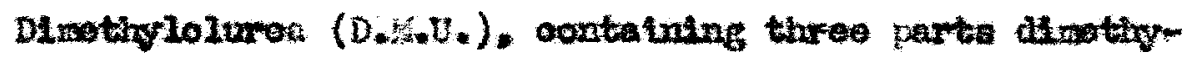
loluroa, ono part uroa, and twolvo parte wrter by wolght, was also usod as an Imprograting agat.

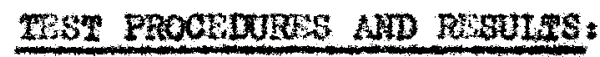

A. Arabortute, RR23

Two sories of wood amples ware lmared in the rosin, one complotoly and the other to ono half tho thitelunoss, for 6,12 , and 24 bour portod8. Arter inoralon. all samples voro gubjected to a 24 how diffurion parkod in a nonmorying atmowinar and then oven hoatod for 24 hars at 1450\%. Following this arying periad, 
the camples were oomaresbed ono hilf hour at $300^{\circ}$ F. Fith a prosture

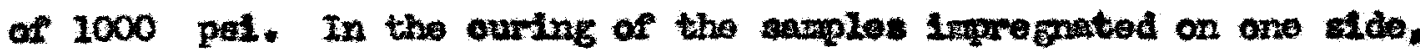
anly the troated atdo wat abjectod to the high toratrature. The othor was held at roon temporature. All heated platone woro coolod bolon $220^{\circ} \mathrm{F}$. bofore the proasure was roleanat.

Al1 saples had a bard, roddish brown high gloss eurfaco. Howevor in erory ane the penotration was novor elopor then tho

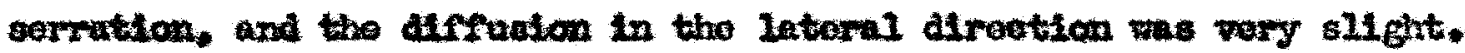

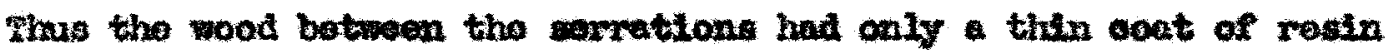
analagous to a probeotlwo oooting and was totally msatiafaotory as en Ixpropated surface.

Iromegation at elovated tomporatures $\left(200^{\circ} \mathrm{F}.\right)$ mas tried

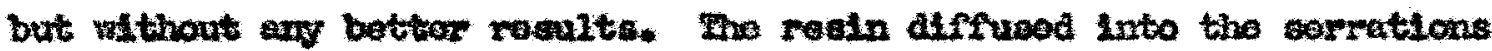
but ponotaratod the rood only slighty.

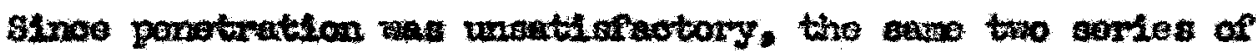

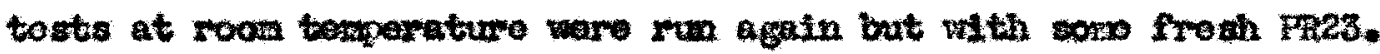

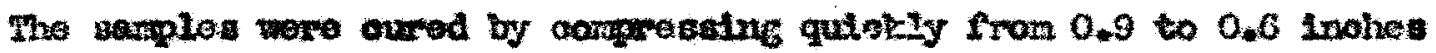

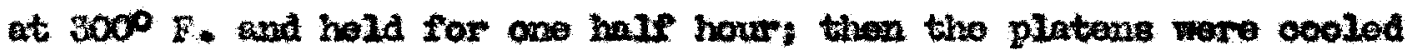
to $220^{\circ}$ Find the prescuro reloasod.

Tho resulting ponotration was only all ghtiy bottor with this

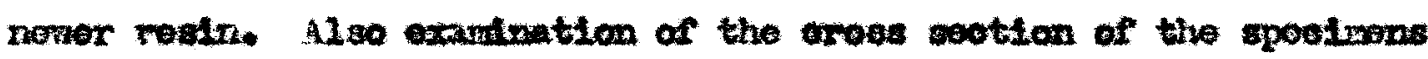
under a low power monosoopo indseated that ibo rosin was not so fuIly ourod as the first batch under the sape oondition. It st111 had 1 te

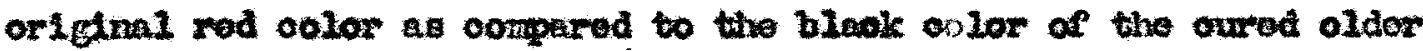
rovin. 
Thase tost inaleate quite conolusivoly that atmospherle

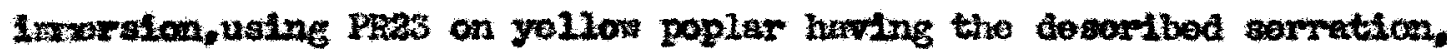
Is unsatiafortory.

Alumimn, tin, and stoel wore tosted for neo as oauls to at atribute the hoat ovonly and to Impart a mooth, hard, glessy anfiace to the wood upon owring. All theoe lmpartod rory good aurface, If thoy wowo pollshod, but both the alumimua and tin had moro of a tondeacy to otiok to the opoolman than the harder stool.

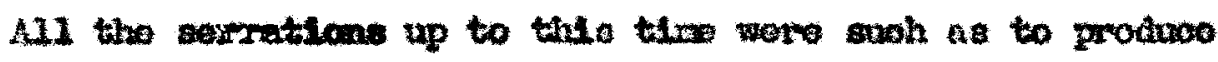

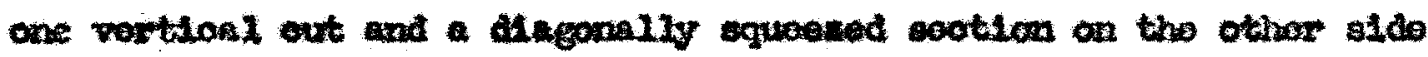

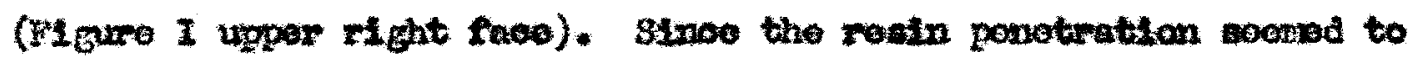

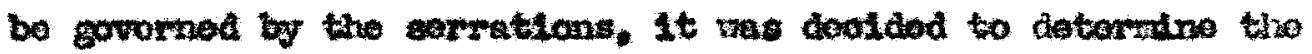

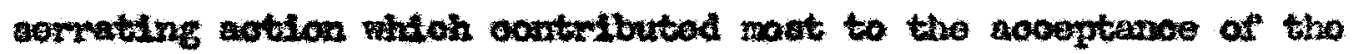

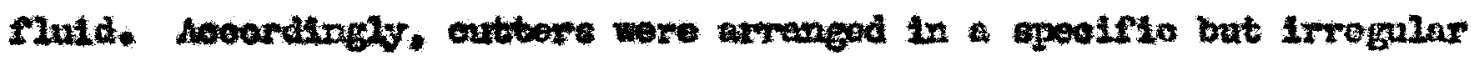

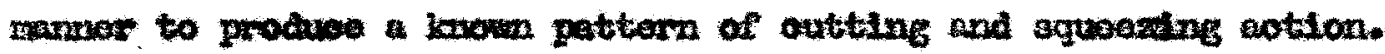
Improgation of amplion having this Ixrogular patterm ohowed that the

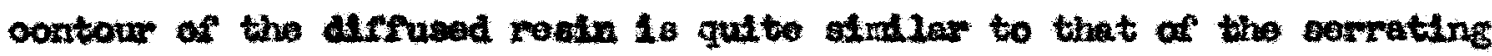

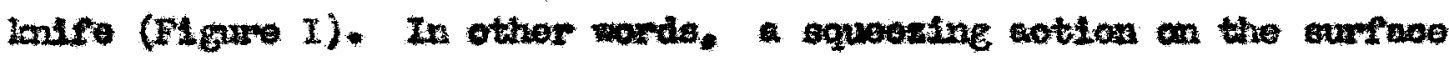
naterinly alds wabequant difrualcm, and thorefore a broad ahallow somating tool $1 \mathrm{~s}$ to be dontroc.

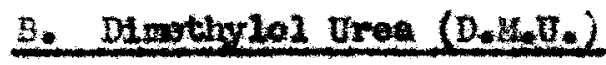

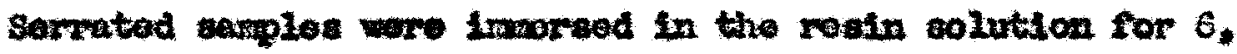
12. and 24 hour poriods th arfuston parlods of $24,48,72$, and 06 hours (total 22 amplos). Thaso woro then placod in a hot platesn

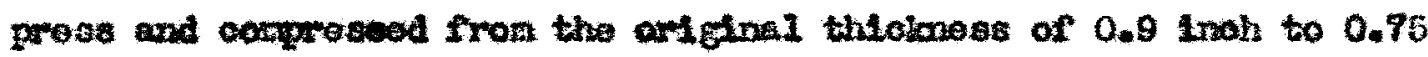
Inoh wh the final thicleness held by ztool stop blooks. 


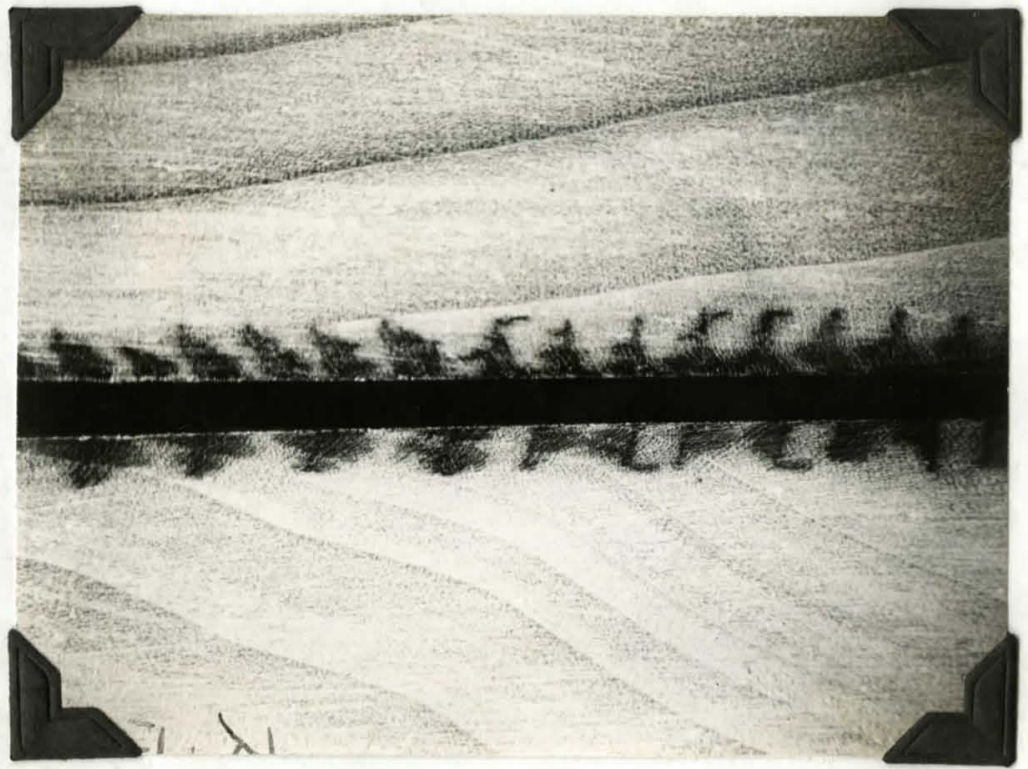

Wig. I. The refeet of Semratsons on Surface Imprognetions. (thage $3 x)$ 
Iratrination of the twelvo spoolnens showod no epparont

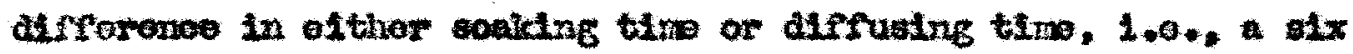
hour soak and twantymfow hour diffusion porsod produoed a basplo visually oorperable to a twenty-four bour osalc, ninoty-six how:

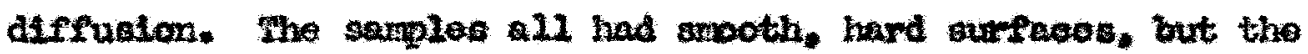

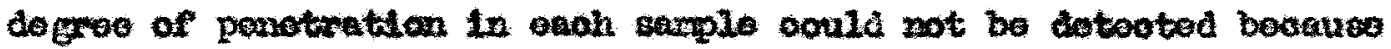
of the sintlarty in oolor betwoon the D. Each of the samples wore subjootod to a trop surface notisture tost with the wator opot ocotinually roplentshod as it disappared. Thow was allght raies in grain under these condtatane. but It was dorintely lose than on control spoolion af untroated wood.

Beoanso of a lafect in the peos, one of the above bamplos

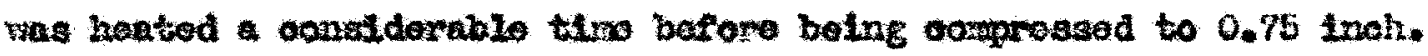
Epon oxamation it wa foum that this sumplo had a rolativoly 100

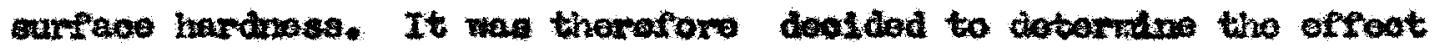
of greasure upon tho final oured products.

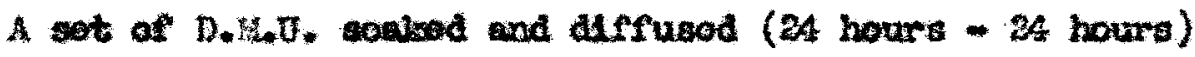

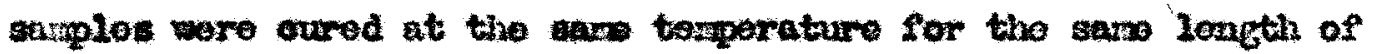
thin but with presenvo agplled at vartous intarmals of ouro (Table I). A sintlat ost of platn water novicod apoulwans was aloo preparod. The reaulte on the D. Fot. anples, tabolated in Table I, ahon that at ocnstant termorature, time, and peroontago coscression.

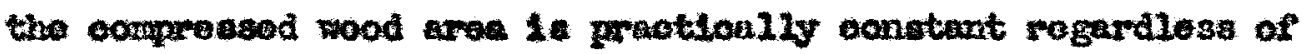
variano in method of applying mossure. It can aloo bo ocen that

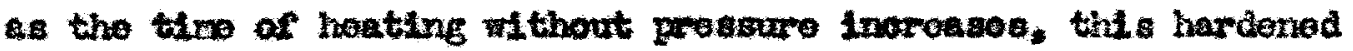


oompressac wood aroe nowes from the aurfooe towards tho intertor of tho wood. Ints phowomon, thongh also wregont in the mater sonked anuples, is more promonmond in the D. of the ouring cotton of the rotin upon houthg.

Thoso rosulta are abon plotorially in Fguros $2,3,4$, and 5, the compressed aroa boing the dark portion having the wavy modullary rays. It is ovideat that the hardanod oongrobsod aron

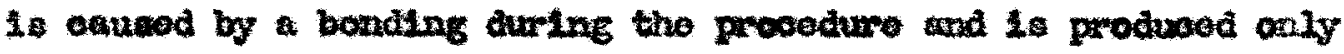

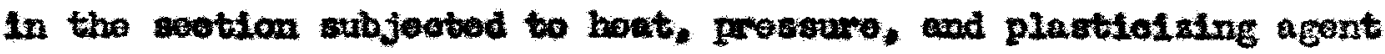

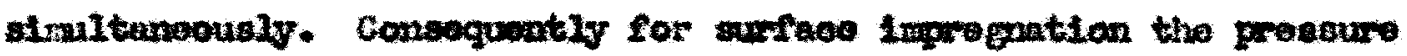
at final ouro should bo epplied inasdiately and quiakly to Inouro a bardenod surfaoe and ooft core. 


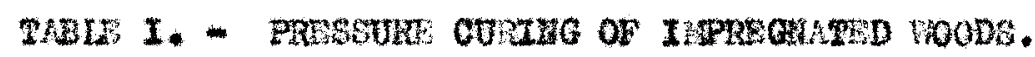

D. L.U. Ireated Yellow Poplar

Wethod of Compesoing

Is. Qutekly proued by 300\%: platens to 0.75 Inoh stop blooks. prossure and hoat rotalnad for 1/2 hour, 00010d to $200 \%$. in pross.

Ib. Surfaces brought in oontegot with $300{ }^{\circ}$. platens for 5 minutes then preserure appliod and anglo finithed a. Ia.

I0. Surfaces brought in contreot with $300 \%$ s. platens for 10 mutos then proseruro applied, and surplo fint ahed at Is.

Id. Surfuoes brought in eantact with $300 \%$. platens for 15 raluntes ther prosenro applled, and sampio finfohed ac In.
Weoult:

Tho ounple thowed a hardionod outaldo odgo $3 / 32$ inoh (apyrox,) wh thard oompressed vood oharaoteristios (M1gure 2a.).

The dato had soft exterlor with a harder oomrrested wood area beglming about $6 / 32$ Inoh from the outalde surfaces and oxtending alrost to the contor of the sootion. The serrations were opon and unbonded oontrary to condstions of Ir. (FIgare 3a.).

The arale strewed again the saft exterlor whose arow oxtended towards the osptor about 1/4 1woh and then a bard ootion extending towards the conter 3/32 inoh (FI gure 4a.).

Coraparable to Io. exopt that the hardor area had ahtifted to the oontor (Figure ba).

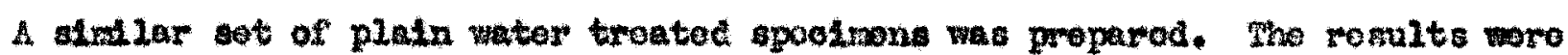

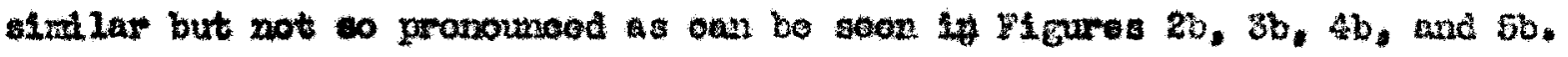




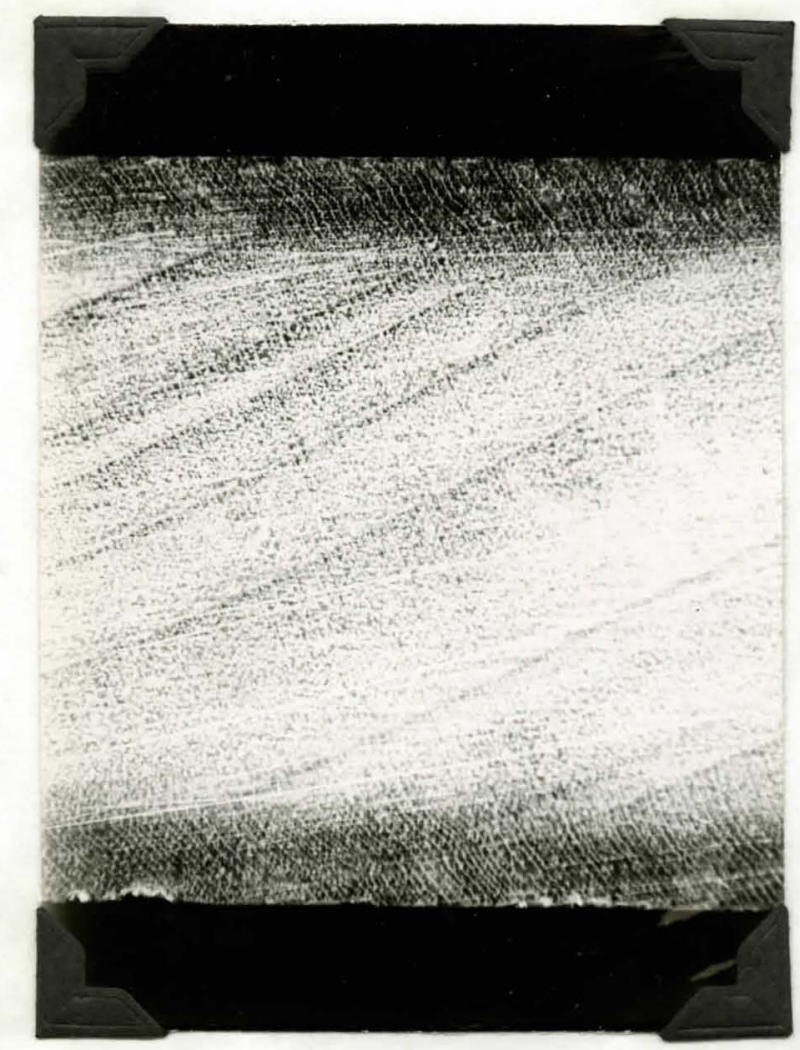

a) D.13.U. Imppregnated.

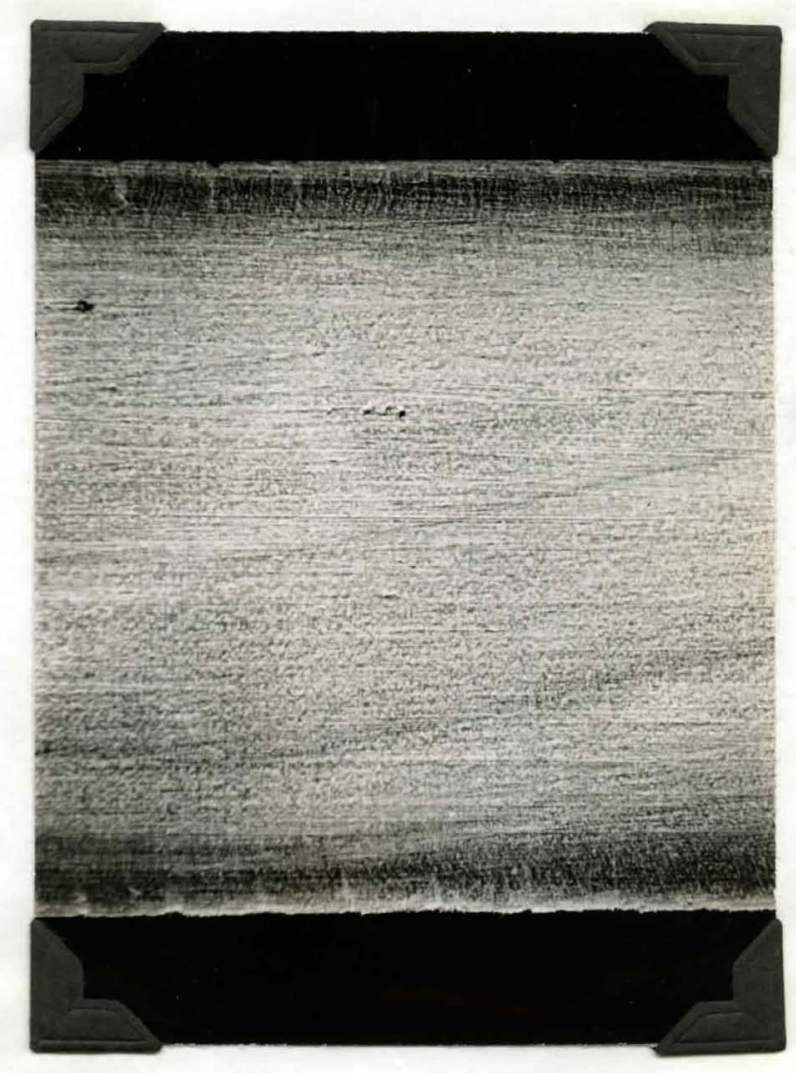

b) Wistor Sosisod.

Pige 2. SImitenoous Applseation of Pressuro and Itoat on Yollow Poplar. (Vlag. 4X). 


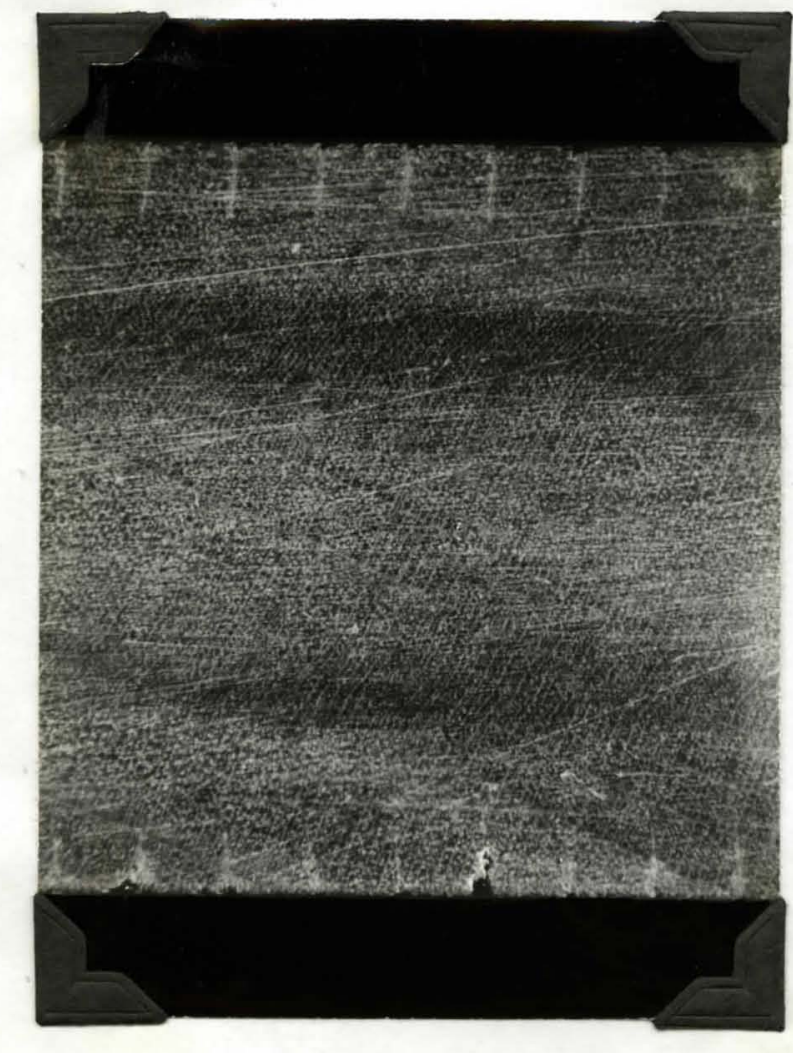

a) D.W.V. Inprogatod.

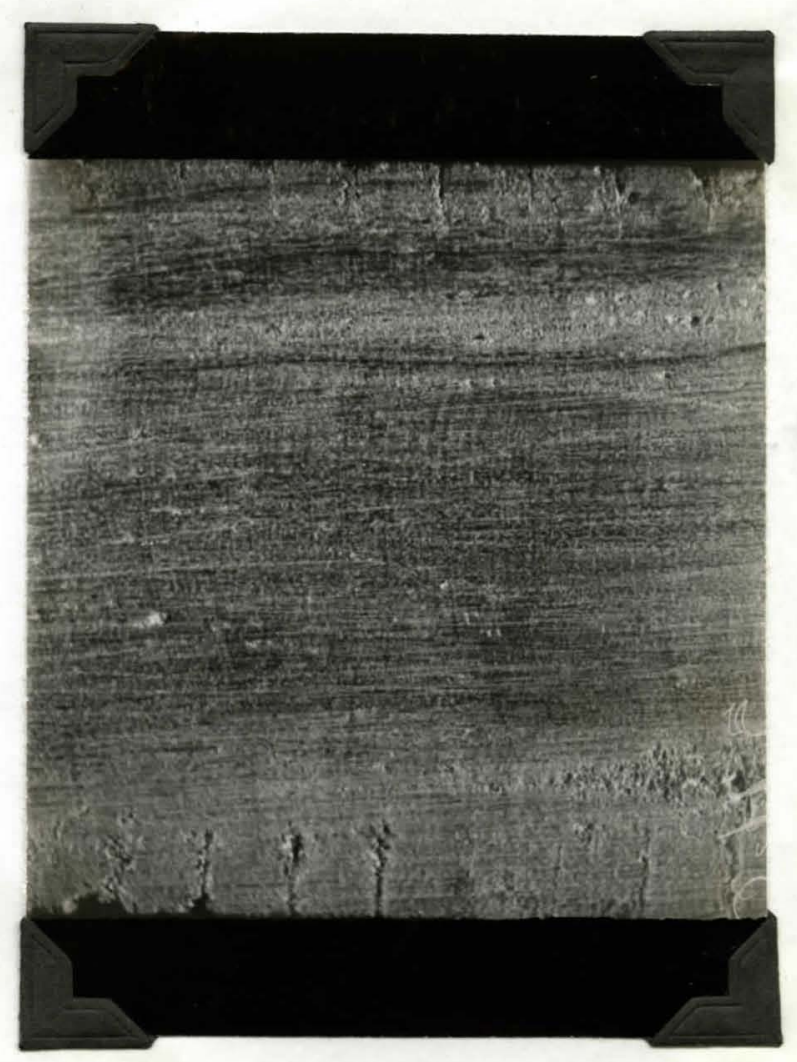

b) Wretor Soakec.

Fig. 3. Mressuro Apglied to Yollov Poplar Aftor 5 lanutos Hoeting (lag. LX). 


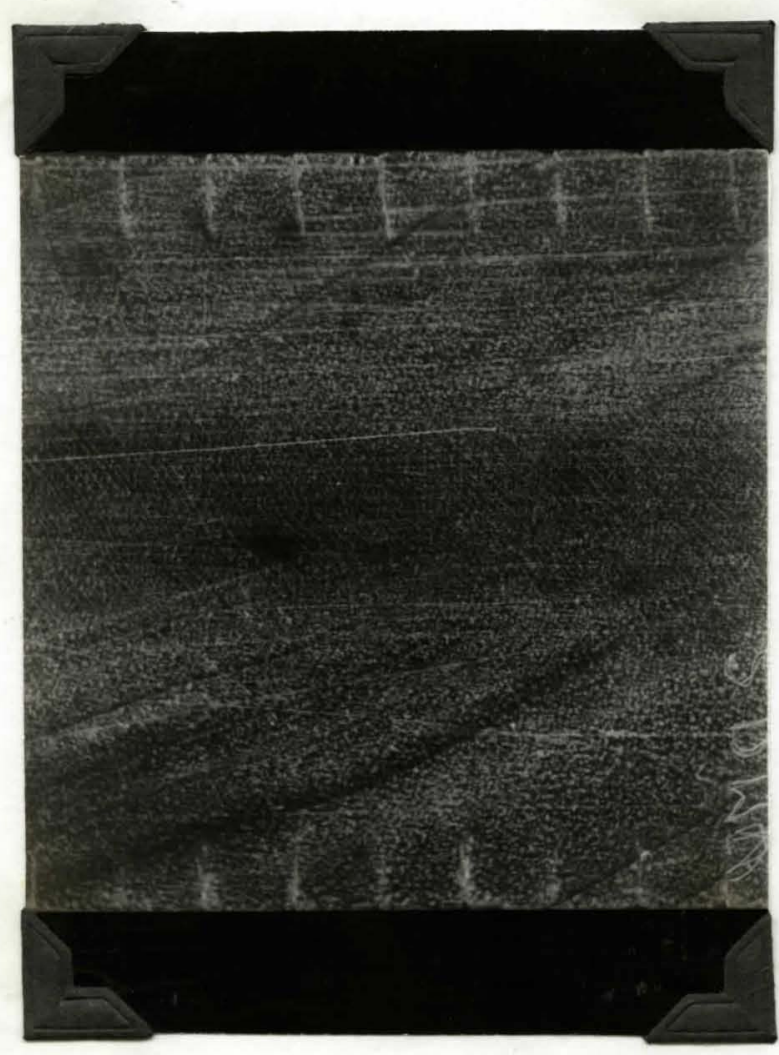

a) D. If. V. Intpregatod.

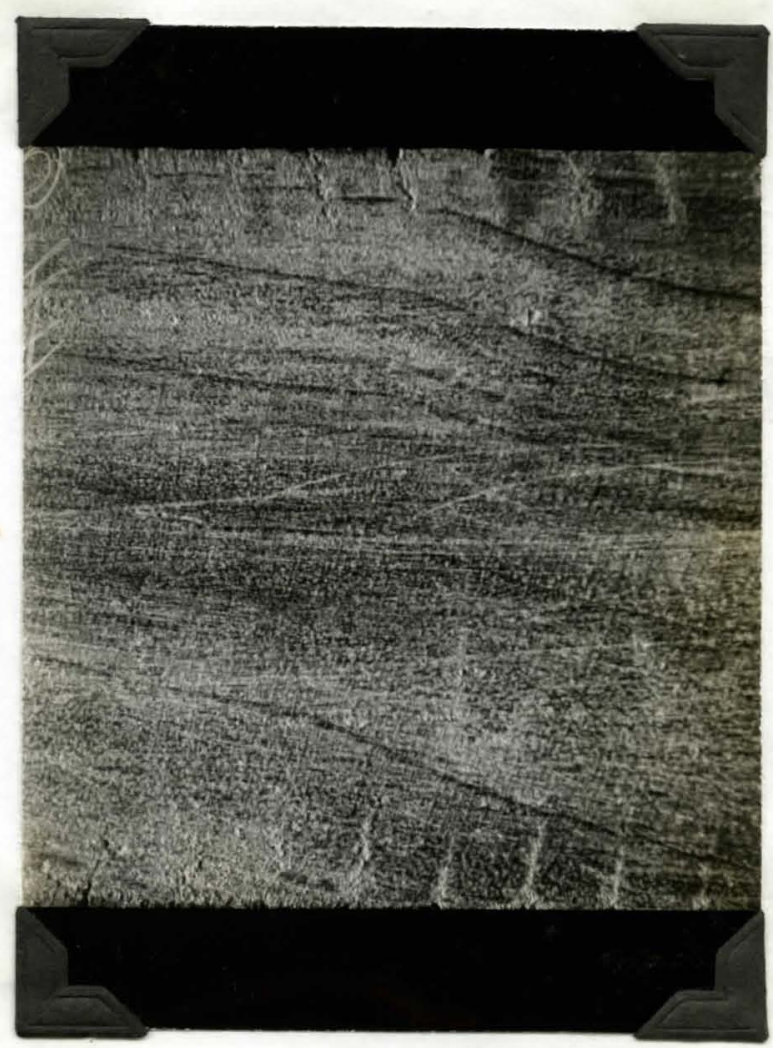

b) Whior soakod.

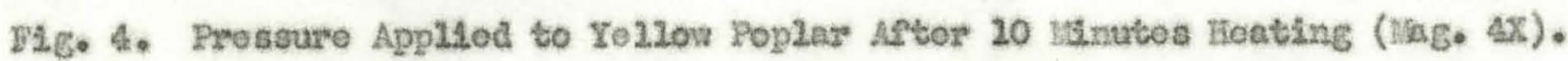




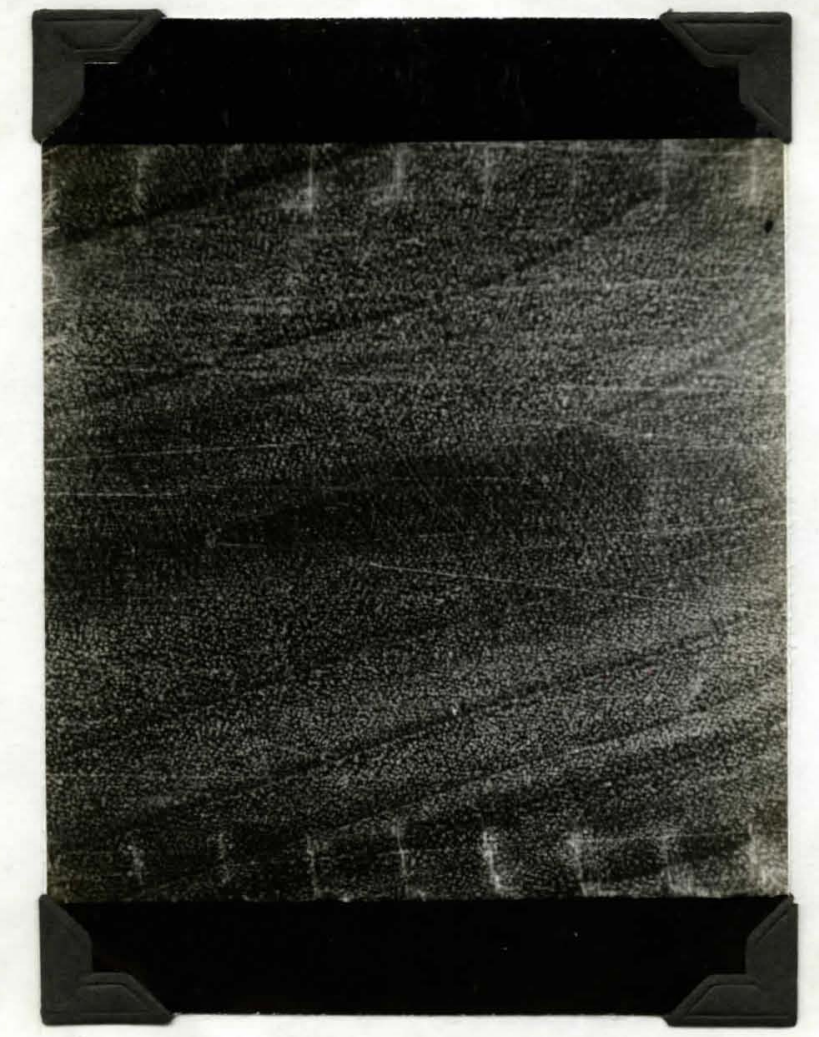

a) D.It.0. Irigregratod.

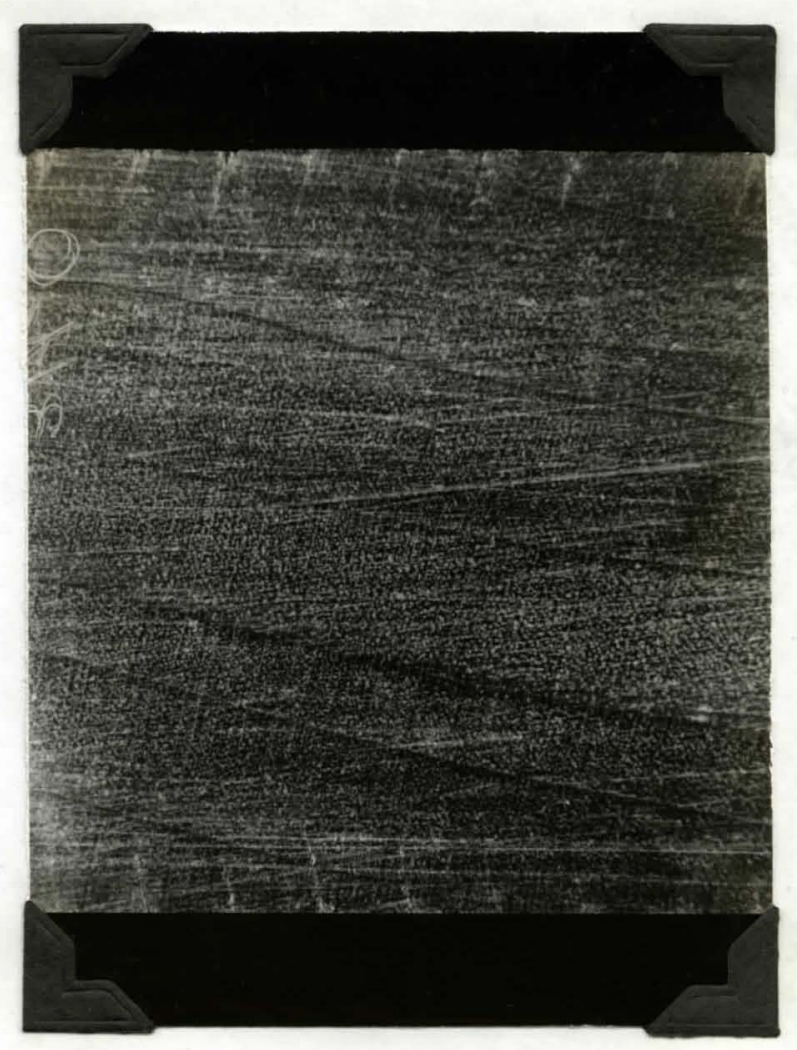

b) Water soulsed.

Fig. 5. Prossuro Applied to Yo120w Poplar Aftor 15 Jahutes Hoating (ikg. AX). 


\section{B. 5roposante passupe}

\section{AFYBRATUS:}

A steol prosaure oylindor (six inolwes inste diarotor and

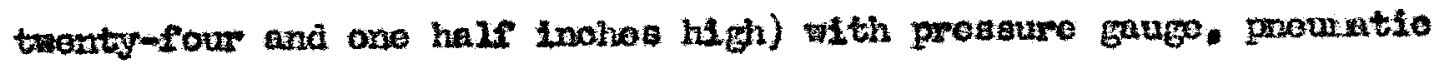
peossure oomostions, and a stainless steol bucket, was used in the Improgution of the rood sayples.

Mytsis:

Yellow poplar $(4 \times 4 \times 9$ inohes).

Anitorl1te PR23, a powdered phenollo type rosin (30 parts by weight) plus water (70 parts by welght). Total solid so peroent.

Pormatex No. 2 ueed an and soulor.

FrochDors:

Thood samplos were plwoed in the botton of the stainless stool buekot and imersed in the irquogating afont. A poumatio prossure was then appllod and aftor a promdotorkinod tiwo roloased suddenly. The samples ware thon alr dried. All curlne was done at $300^{\circ}$. - hall hour comesed from 0.9 to 0.75 inch.

\section{Moth AID BisuLis:}

A camplo (ocmtaining all saprood) cubjeotod to linprognation under $85 \mathrm{pal}$. for onemhalf hour was found to be thoroughly inprognated. The time wae out dom to 5 rinutes, but there was st111 sowe ond ponotration extending tho langth of the ploco. ponotration froa the faces axtondod to an avorage of $1 / 16$ inch doep thougl it was not 
untforn. Stdo ponotration negligble. Final ouro produod hard aurfacos nbout $1 / 20$ Inoh and left the rost of the wood, ineluding that whloh had boen treated by longttudinal ponotration, sort.

Sineo wood is moro ouscoptiblo to longltucianal ponetration than temgentiel or radial. the high hydroctatio prossure aooeloratod this ond ponetration whout grotily affooting the other two.

It was therefore decided to seal of the ends of a sample with Parnatex Mo. 2 and subjeot it to the sand oondtions as the last

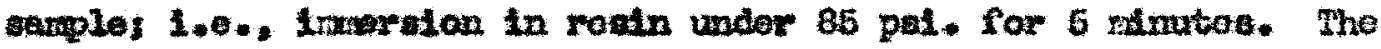
realt was a produot baving no and duffuston but unforaily in

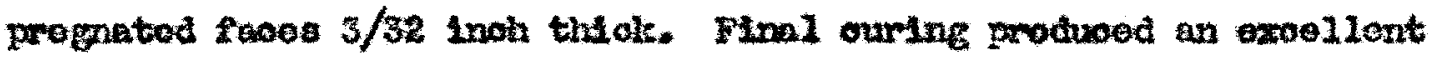

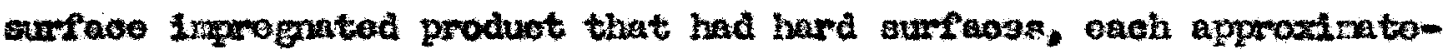
ly $1 / 10$ inoh thlok and a soft coro. Tho sucoecsful romits were efrected on poplar oontalntre all apmood. It was thon doolded to doterntino the porsetration in the hoartacol. A sanple haviag plats heartwood surfeses snd anothor containing a aerreted honrtwood surface vore anbjeoted to proseuro inquegation of 85 psi. for flvo matutes. Both sayplos were and bealed before treatront. To penotration coourred in the plain hoartwood sarface. but a untorn

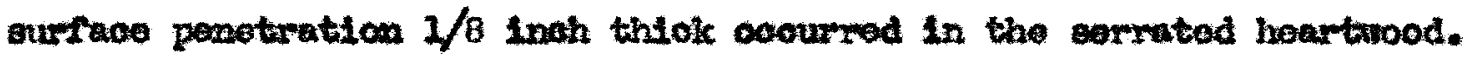
Additlonel toste nocoseary to confim theso swovesaful rom sulte had to be oarried out using PR-60 reatn as the manufature of PR-23 was stopped. Eowevor sinoe the PR-50 ald not 17part axy color to the rood apon iryregation, an atterpt as ado to find a autablo dyo. 
The following ohenteale woro tostod in a PR-50 solution $(30 \%$ solds).

\author{
Carbon Eladk (2\% by pight) \\ Lawp blaok (2\% by weitht) \\ Anilino sluo ( 1 gan. por 2 iltors)

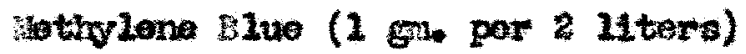 \\ folviono Dycroohioride (1 gor por 2 11tara)
}

the anlitno blue, nothylano blue, and retiviene bydro-

ohlorido proved onocosarul in giving the reatn e groen oolor which panotrated Into tho moed with the realn. Howerror. upon ouring tho groen oolor diappoared, and tho reatn beoaro praotically coloriess agatx.

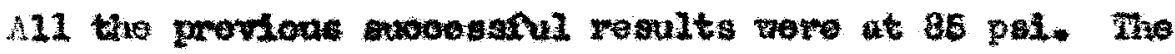

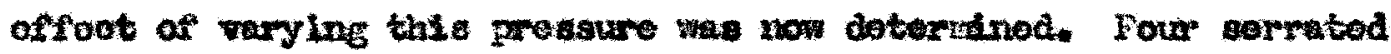

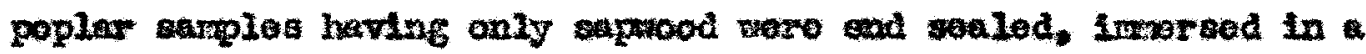

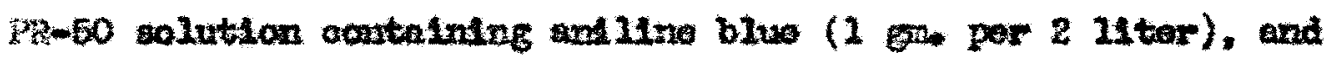
tubjeotod to $20,40,60$, and 80 pet. roppeottroly for 10 minutes.

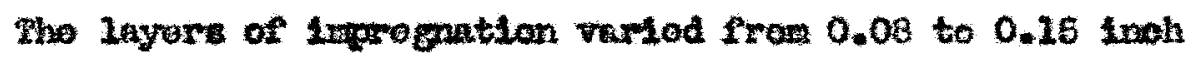
in 011 four samplos and no rarlations with prosauro could bo formd. This indicates that in the bhort timo of troatwent the rouln 18 oasily difrubed through the ampatod wood surface - a dopth of 0.06 to 0.07 Inoh - oven at low proseure but that pat the depth of sarration tho rato is too slow to shom vartation alth prosidu. A longer porloc

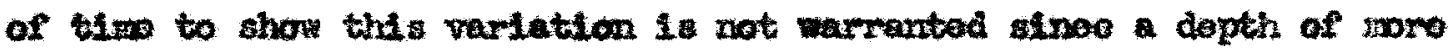
than 0.25 inah 1.5 undestrable. 
US00S101:

The waromatio prosoure method is an eany, guick, and

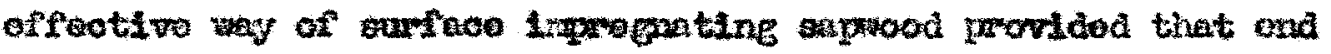
diffuatom an be revonted. Fowever this nothod is of no nee on vood oortalining hombood surfaces unlose thoy have boon serrated. Theso serratians tond to salio it posetble to prodioo a nore

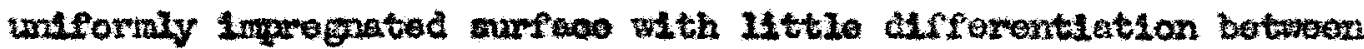
Doart and aspoods.

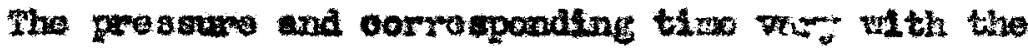

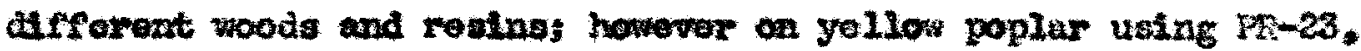
35 pot. (Gaugo) for 5 minutes was atlafaotory. In comorolal preotice the tho any bo too plort and so a oorrequonding lower

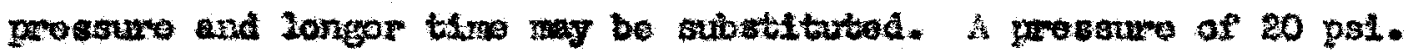
(gaug) for 10 mates proved satiafmotory on yollow poplar with PR-60. 


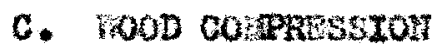

APYAATS:

A th pan was used as a containor for tho wood and rowin

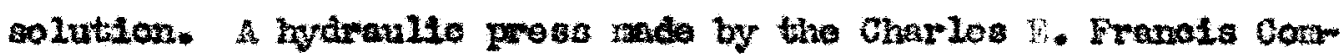
pary (bos Page 9 ) was uod to apply prosenro and flat stoel bars of difforent lengths and withs wore omployed to tranerat this proasure to rartous parte of the nood engles.

MTERAL:

Yo1lom poplar, both plaln and sorratod, was ued as toat sarplob. The sorrations were the oorrontional v chapod aorrations .02 troh lop and $2 / 16$ ineh apart.

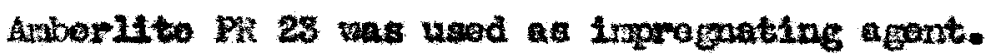

mocrovex:

A arplo wa lald flat on a atool bar in the rosin solutton. and an Identioal bar was plaoed on 1 to top surfeco dirootly abovo the botton plooe. This arsembly was thon placed betwoon tho pletons of the pross and prossure was appliod to compross the nood to a dafint to thiclenoss. After oomprobalon the prosburo was roloned. but the nood

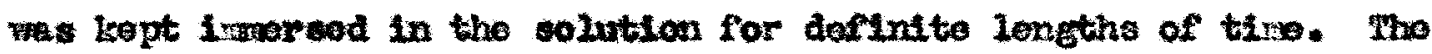
auples wore than alr triod ono day and sanod in two. All ouring was dono (atcor atr tryling) at 3000\%. for a balf hour at a prossuro necessury to oomprear the wood from 0.9 inoh to 0.75 inoh. 
DATA HDD RESELS:

A somated straple $(4 \times 8-1 / 2 \times 0.9$ inolwes) was soukad 48 hours in weter before bolng composead in the moln aolutican to 0.5

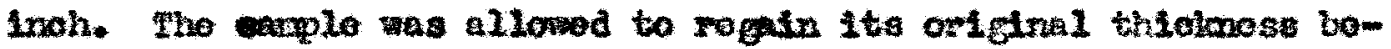
fore 16 wan renovod (24 hours). Tho powotration of rosin was theoughout the thiolones; but it was vary non undfora, and thero whe Indication that groat exout of and alffusion took place.

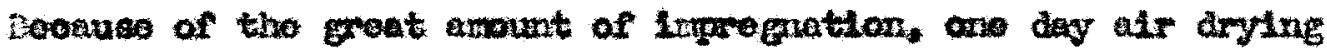

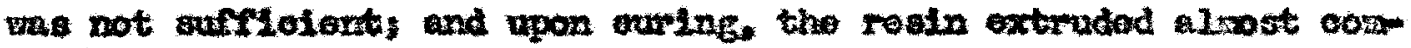
pletely lowing only a vory then anfaoe laver.

A plain aample $(4 \times 3-1 / 2=0.9$ inohes $)$ sooked only $1 / 2$

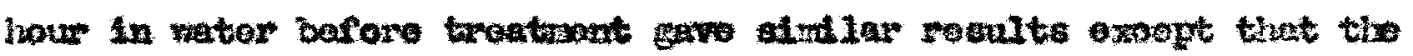

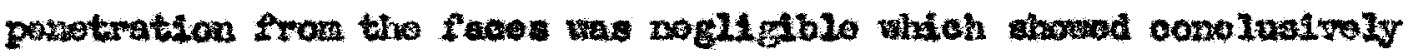
that the rowin had rollowed the fiber axis dirostion.

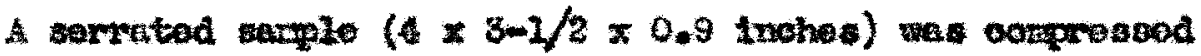
In solution to 0.75 inoh. The romits wore atilar to those of the othor samples. The penotrattion was throughout but rery non unform. A soeond sample treated the samo but having ita onds sealod (Perntox No. 2 - soo Pags 20) had and panotratican of ahout 1 inoh.

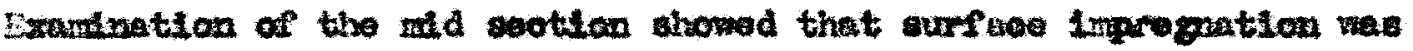
not unform, and vallod frow 0.0 to $1 / 6$ inoh in depth doponding on Its position with reapad to the serration. The oross botion rem

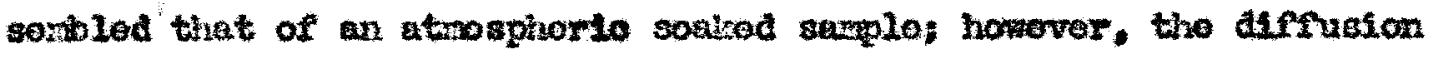
fron the aerrations into tho wood wore moro pronouneed in tho fornor. 


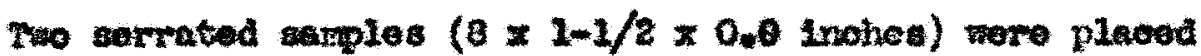

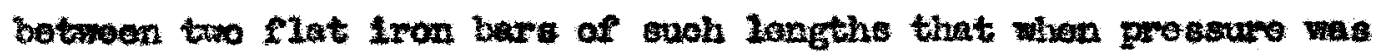

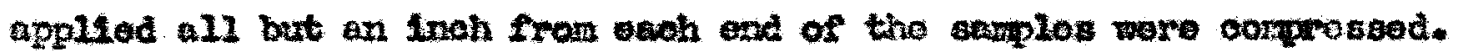

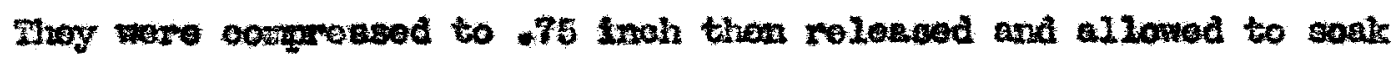
for 6 minutes and 24 bours rospoetively. In both samples the

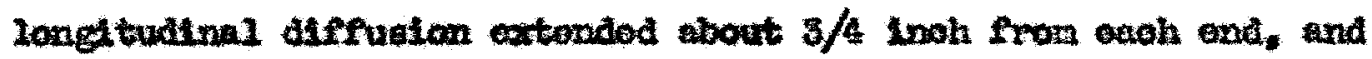
boeause of nupturo thore vere som perts in which ponotwation hat oxtended Iateraliy into the wood for about $1 / 4$ inoh. However two

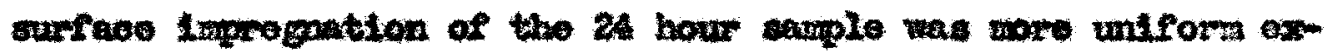

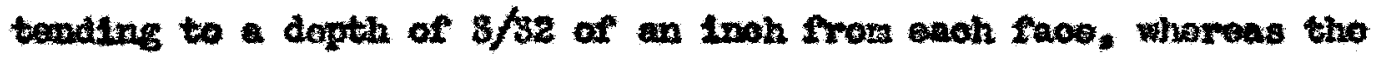
5 sulnute axalo had lanroguatod facos varylng from $1 / 26$ to $3 / 82$ noh doop.

It has boen shom that a sagple inohe lone ocraprosed to 0.75 Inoh onoountors and difruston thoughout. siso it vas noted that aomprosing on inoh Iongth in which an inoh from each ond was not subjooted to preasume oaused only $3 / 4$ inoh ponetration from the onds. It the thoraforo deolded to detornino how far tho end dffuston actually prosoedod when tho valo samplo 15 rubjoctod to coxarrosston.

Two sormated samples ( $6 \times 1-1 / 2 \times 0.9$ lnohes) were oon mroseod to 0.75 inol, raleabed in solution, and allonod to woak 5 wrutes and 24 hours reapeotrivoly. The 5 minute axple had in

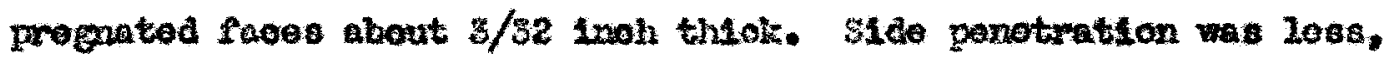


and longltudtux was atout $3 / 4$ inoh. Tho 24 hour saxplo ahored

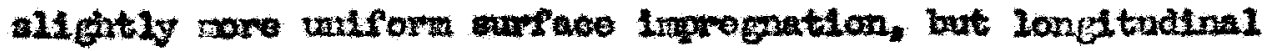
ponetration axtronded the whole longth of the plowo.

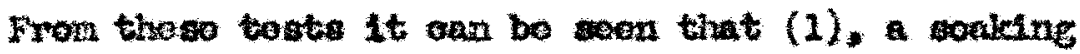
pariod aftor tratrunt is novedsary to inouro proper ourface

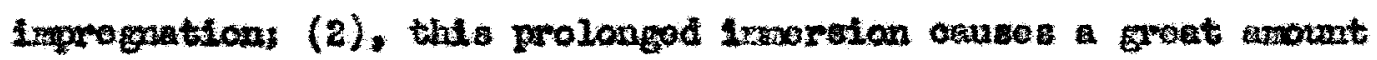

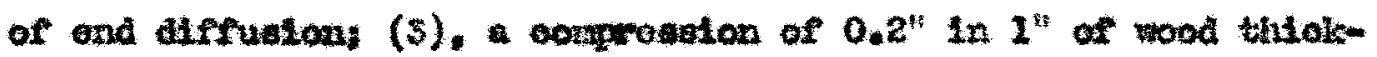

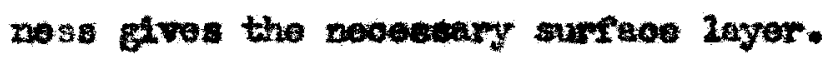

It was therefore dooldod to otudy nore olosely what heppens at the curfabe subjeotod to prossure.

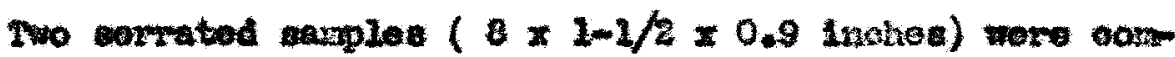
prossed to 0.76 thoh only at their oontore by moune of flat bers abeve and wolow ontendlng the wath af the paces and $1 / 2$ inoh of

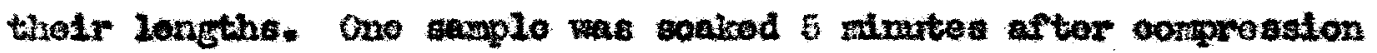
and the other 24 hours. Tho 5 mimute sample showed alf

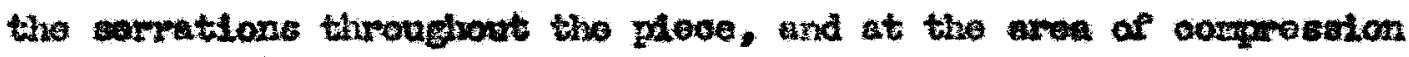
a thin wetern layer of rouln about 1/32 inoh thick on woh fwoo.

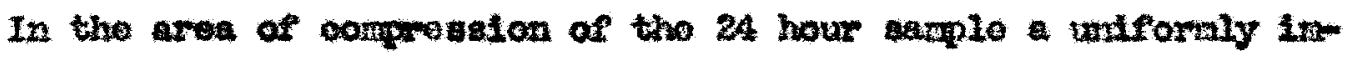
pregrated aurfaoe of $1 / 8$ inoh thicic oxisted on each free. Upon axamination of this ares it was found that the resin had porotrated from the fooce to dopth of $1 / 0$ inoh and then travellod longttudinalIy a sall atstapoo oech way.

Pron these Iest toats thare is indioation that curfaco Lrmproguating wood by a Eothod Imolving actual compresston of the wood In the resin is fonstblo under controllod oonditlons. 


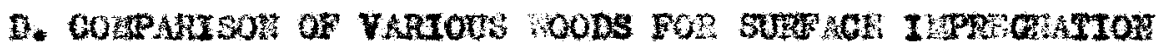

Fins fourth part is afvided lnto two sootlons:

A. Heot of ifycrostatle Prossure Improgation on Varions Toods.

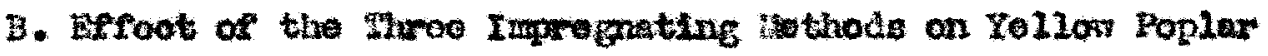
and Black Gum.

A11 ewoeoseful resalte reportod nsting the hydroststio prossare

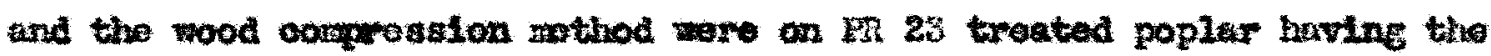

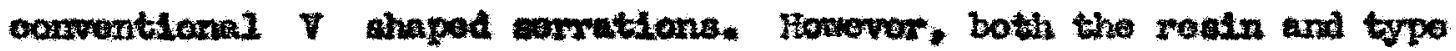
of corration ware bade wharallable before safflolent data oolid bo neownalatod.

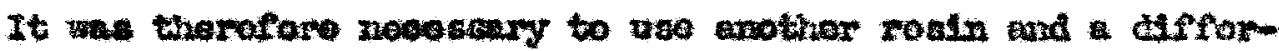

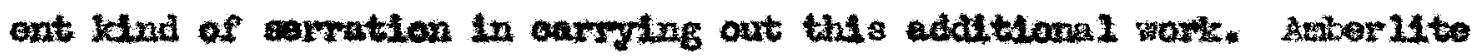

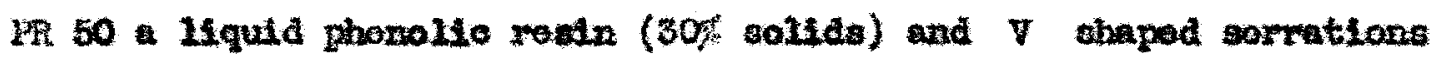
1/16 Insh deop and spaoed $1 / 6$ inoh wart were ohosen.

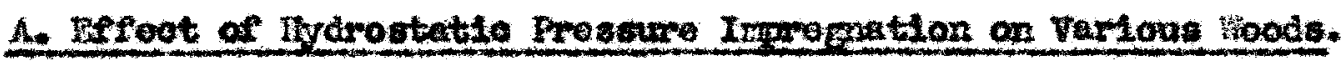

WoOs ThSTED.

black am - Contining both hoartwood and sapwood. Bass - Contriming Doth heartwood and sapood. Aspon.

Cottomood. Soth platin and sorrated ptooce of onoh spocilos approxirately $20 \times 4 \times 0.9$ inohos tortod. 


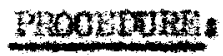

The wood samplos wewe ond sonlod wth tomates no. 2 then

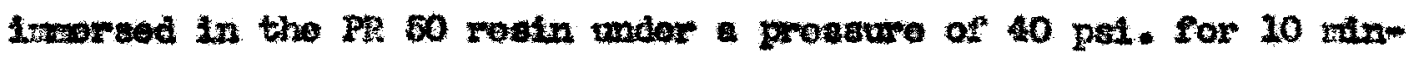
utes. inilino bluo was alded to tho rostn ( 1 ga por 2 Ltors) to Irapart a color to the wood. All samples wore atr dried 1 day and then out porpandioniar to the main to obserro tho depth of ponetration.

montas:

PInla blade gan anowed no panotratson in tho hoartwood and about $1 / 16$ ind in tho waprood. Tho bowntrod bamplo ahomed wifora ponotration of approxtraboly $1 / 8$ ineh corose both hoartnood and sapwood.

Plaln bass wood howod porotratton an doep as $1 / 4$ inoh in

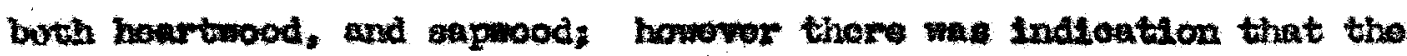
doep ponotration wis due partly or wiolly to ond dueruston indteatine

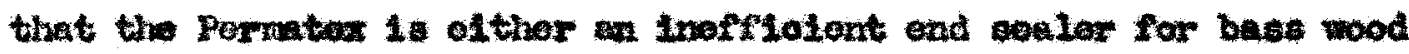
or eno ond gralns nere exposod on the faoes. In the corrated sample

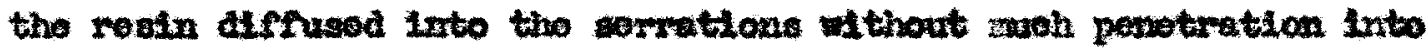

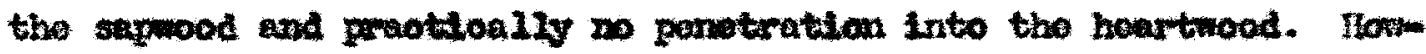
over thewe was alkgt anent of end ponotration in the bourtwood whioh externded tive whole length of the sample.

Plain apon had nom ponotration oxtending as doop as $1 / \mathrm{a}$ 1noh. howover wost of it wat unponotratod. In tho norratod ande rosin affused into the sarrations but nothing nore. 
Plala cottcanood had vary lrregular penotratilons of from o to 1/8 Inoh, but tho wated samplo, althongh having a sianlar ponotration, we wuah nore owaly affuced.

\section{IISGU3atog:}

mough in all the poelos tosted, tho resulte of the corrated

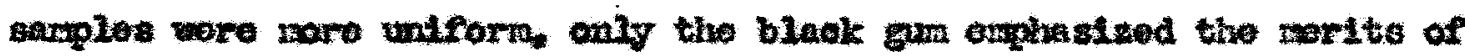
sorwation on hontmood and eaprood.

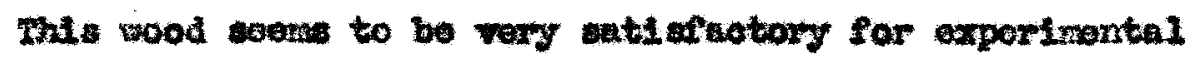

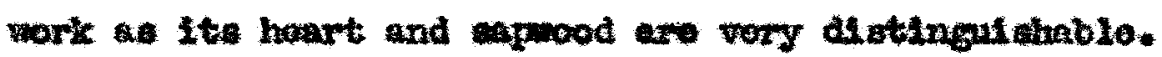

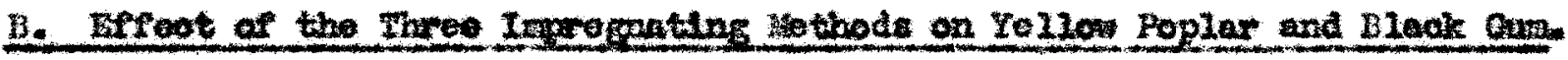
HocREJRE:

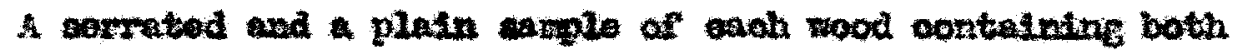
hoartwood and sapwood were subjootad to the follonatng throe toats:

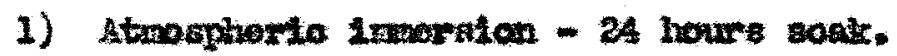

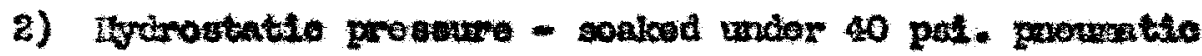
presture for 10 minutas.

3) Wood compresalon - comareseod in solution from 0.9 to 0.75 mol at the midmeotion by 1 at otoel baxe $4 \times 2$ inohe and thon Feloaced and allowed to regain its orighal thiolnees boforo rowoving Prow wintion.

A12 samples wore ond sealod th Porrater no. 2. After

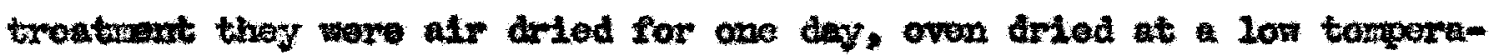
ture (120\% .) for a few hours, and thon out. A plase of each aemplo 
ooxtainting both hoartwood and appood was then ourod at $300^{\circ}$, $1 / 2$ hour, oomperesed from 0.9 to 0.75 inch.

\section{DAPA AND RESTLTS:}

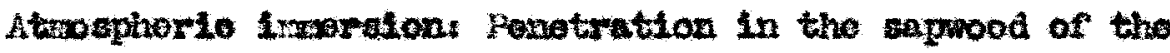
plain poplar was non unforn but oxtended in parta to a depth of $3 / 20$ of an tnoh. Wo diffunton took plave in tho hoartwood. The sorratod

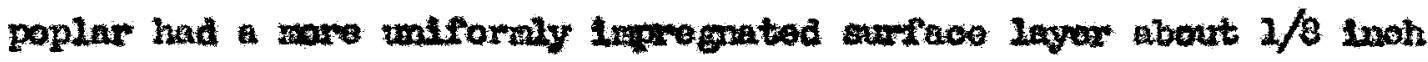
deep. Penotration Into the boartiood oocurrod only in tho serrations. The dffrution in the plain black gas ande was negliglble. and in the sorratod ptoce diffuston coourred in the serrations but only slightiy in tho vood.

Ifdrostatio llosd. perotration in the sapmood of the plain poplar was about $3 / 16$ of an Inoh but absolutely zero in the heartwood.

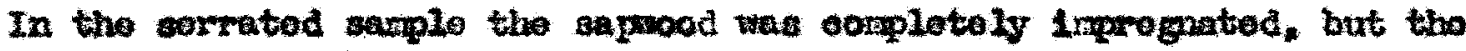
hoartaood showed only diffusion lnto the aemathona.

The atrousten in tho plasn black gun irregular watng in the sagwood from $1 / 16$ to $3 / 10$ inoh and the hoartiood from 0 . to Y/16 inah. ho secratod eazple, however, had an ingregratod layor aoroes the wholo lath varylug frow $1 / 16$ to $1 / 8$ inoh and upon ouring gavo an anoollent hand anfaco.

Hood Conprosetions Penotrethon at the area of opntect in the geprood of the plain poplar was silghtly move then in the rest of the wood. liowever the bartwood showed no panotration. In the cerratod

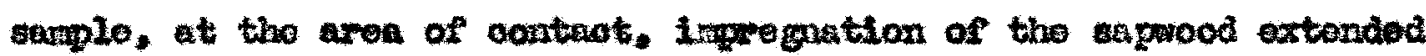


to a copth of $3 / 52$ of an inohy hownor the hoartwood shomad only deffution in tho corrations.

311 git pemetration at the area of oontaet in the papood of the plain black was poroeptbie. Fowever only diffubion into the semations of both hadrood and sapwood oodurred in the sorratod

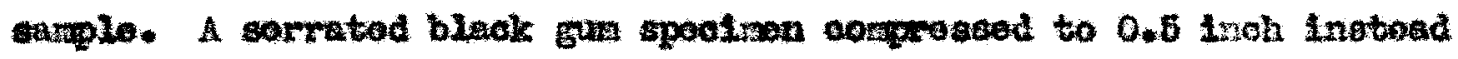
of .75 unteds and though panotration at tho area of oontaot axtendod to a dopth of $1 / 3$ znoh and tapered off towurde tho ends. 1ta rosulta

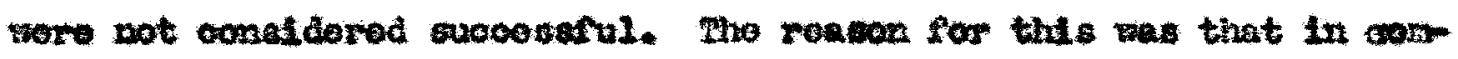

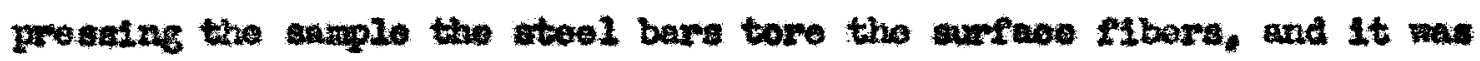
booknse of these brolkon flber onds that tho agparent owocesaful rosults were obtained.

DIstrestow:

The results on the gellow poplar and per 50 aro erratio and

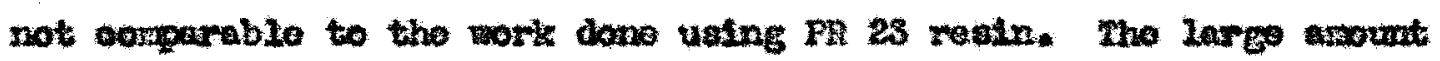
of diffuaton at atrosphoric prossure is noro thin has over boen oncountemed bafore. Howevor tho reanits on blaok gun and 50 sub-

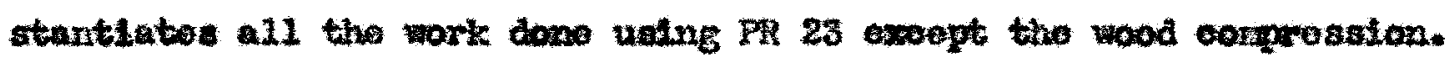
This lattor mothod ald not prove apocosaful. but bocause the serrations were farthor apart than in the provious vork. tho nethod camot be dif rogartod eithout further study using the orlginal serrations. 


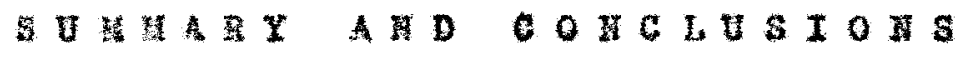


Sho awoess of atmoaphorto lmarstan is funotion of tho

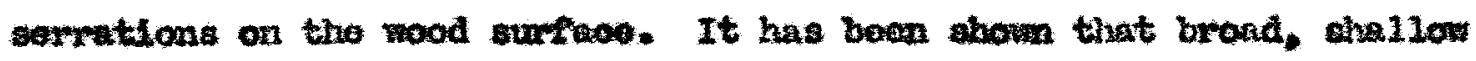
$V$ ahaped exrationg plnoed olove togother are mot farorable to ourfroo inprogration.

The sothod of ouring a surface innegnated produat daterines the find rolative hardnoss of owfwo and oore. If the prosure is

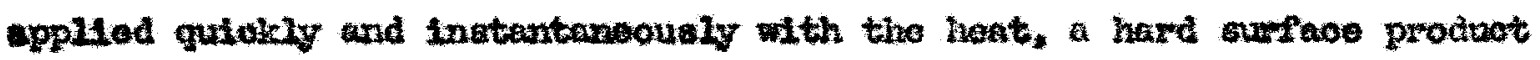

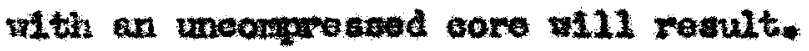

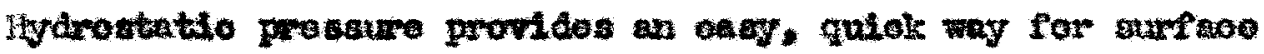

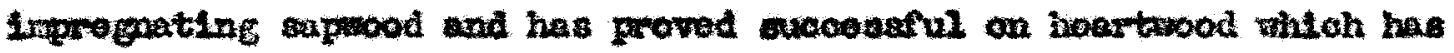

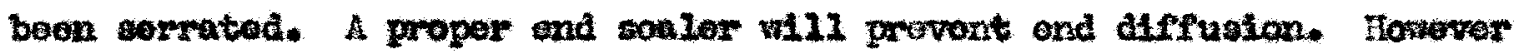
1t has beon found that the prowono of rosin in tho ooro does not affeot

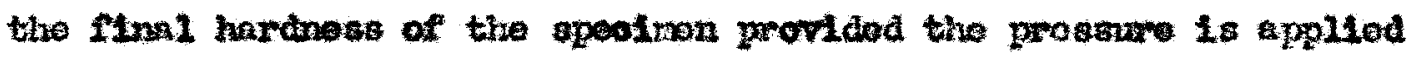

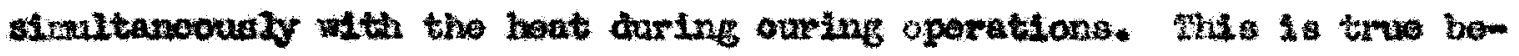
onue a hardenod surface is dependont upon the appliontlon of heat and preasure siraltaneouely. Only the surface is subjooted to such conditlong. A hydrostatlo proasuro of 30 pol. applied for 5 mustes gives

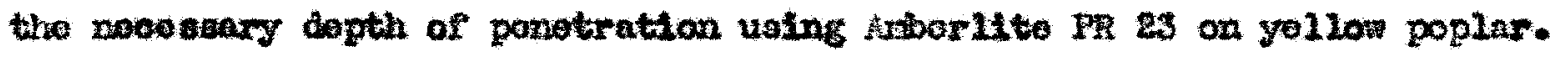

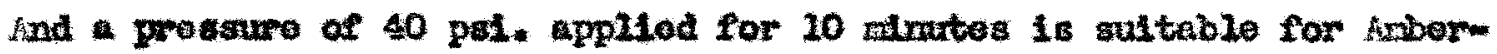
11to 50 on blaok gum

Sinoe vory Intwed swoseas has been mado on the othor two

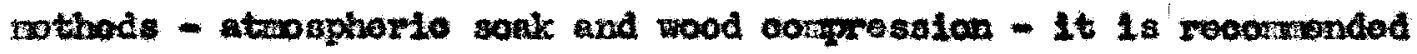
that furthor otudy be mado. Serration having broad, shallow $V$ shapos and lookted closo togother should be trad. 


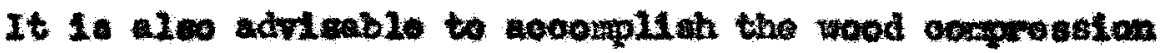

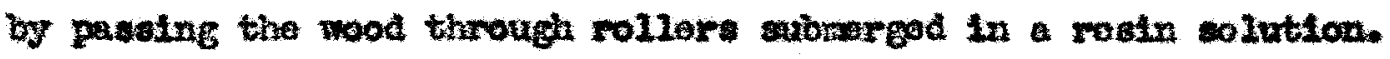

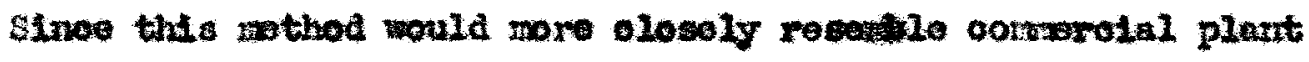

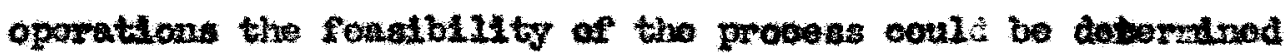
toro ecourately. 
II. G

I 


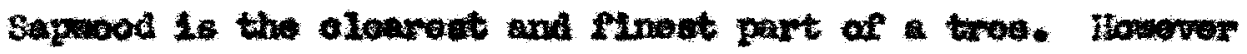

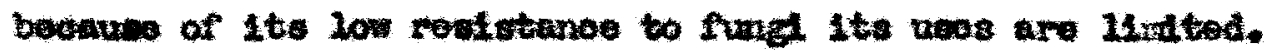

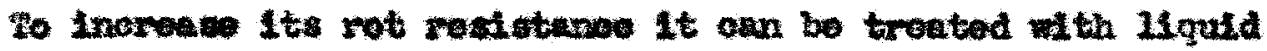
fungtoldse, but this nooconttatos arying and oontrol of varping. It

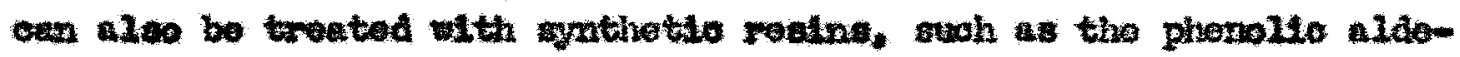

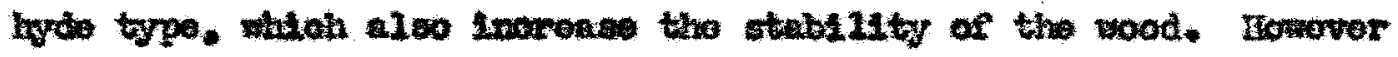
thic roquirea not only drying but ouring and 18 wiso oxponstwo.

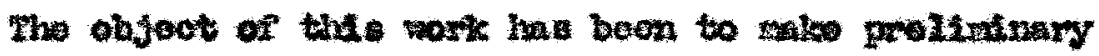

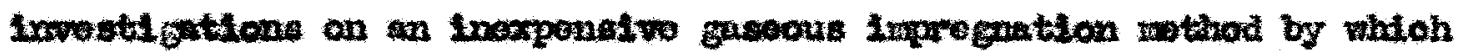

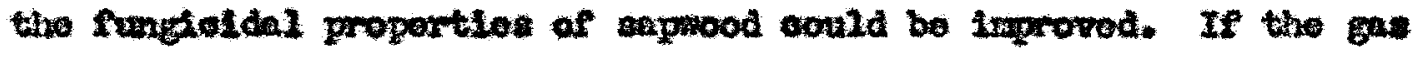

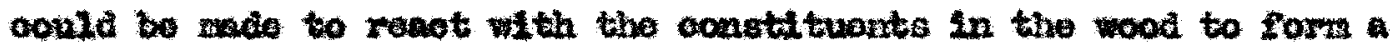

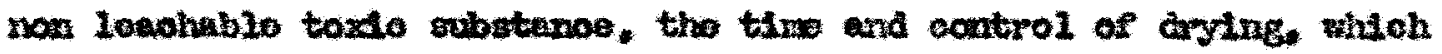

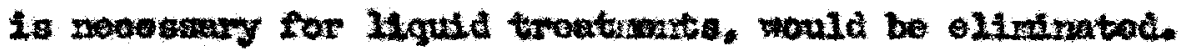


II I O I O A 


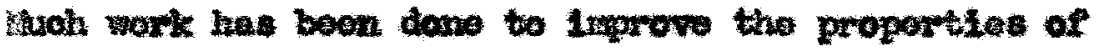
wood. The Inttod state: Departrant of Agrloulture, forest Frodugte Laboratory. has pablishod naw bullotins and papors on this abjeot.

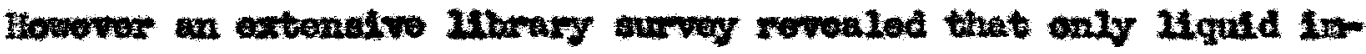

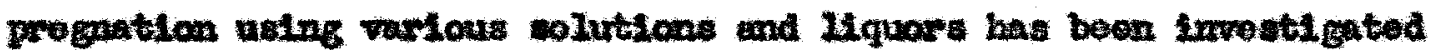
to ary great axtent. In saot only ano papar could bo found on the

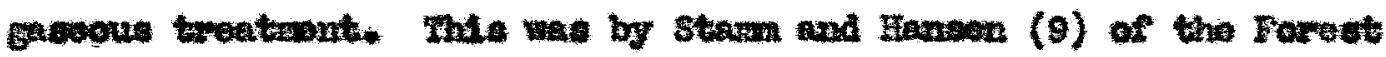

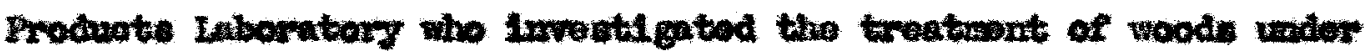

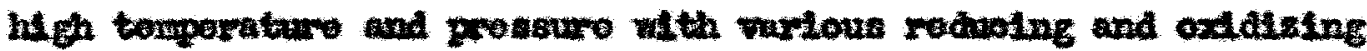

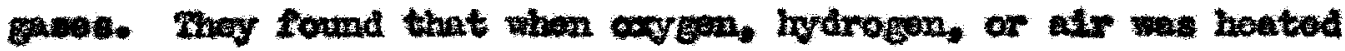

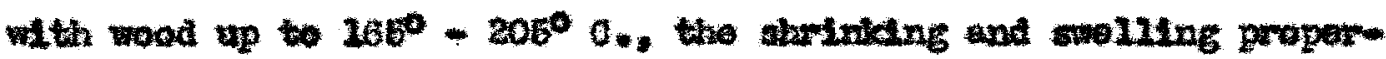
thos of the wood wore potuogd. 


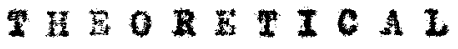




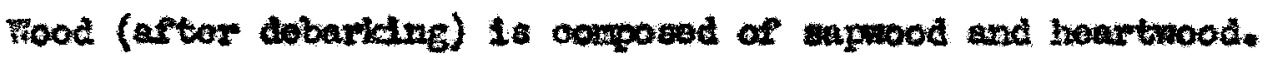

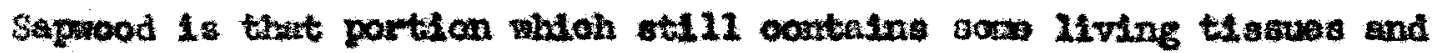
partiolpates in the Ntal aotivitioe of the tree. An the tree oon

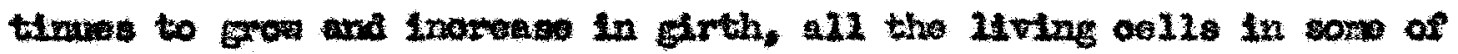
the wood tomarde tho inotid die. This oone of doad tissues in the stem la oallod homerood.

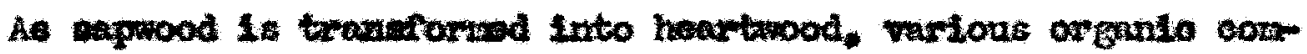
pounds are foraod. Substanoas of this naturo inflitwate into ooll wallo

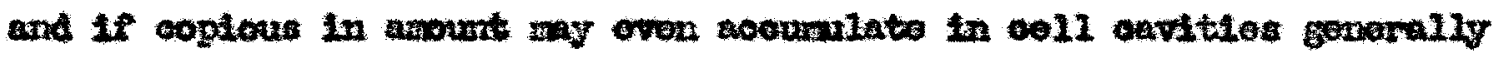

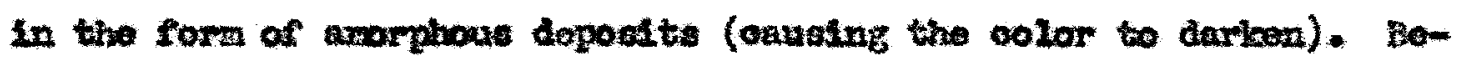

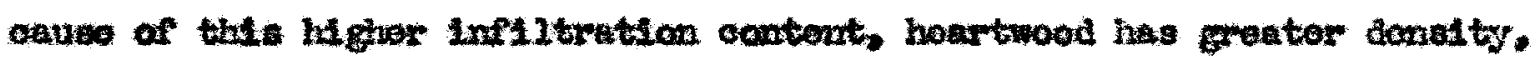

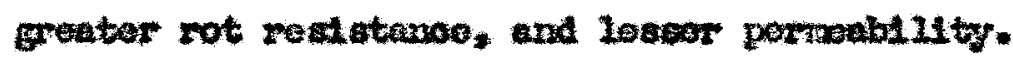

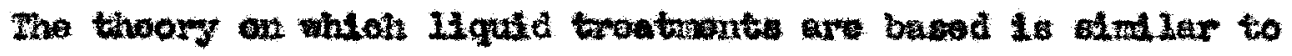
that whito nature uses in chaneting sapkood into hoartmood, 1.0., the

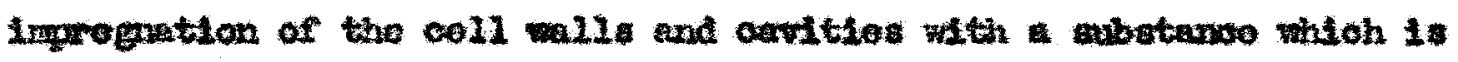

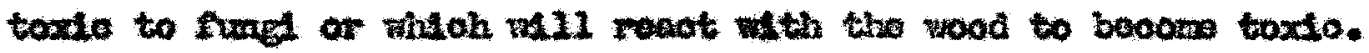

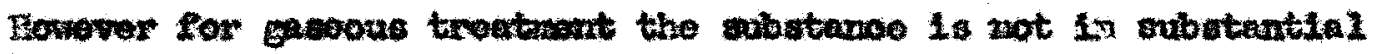

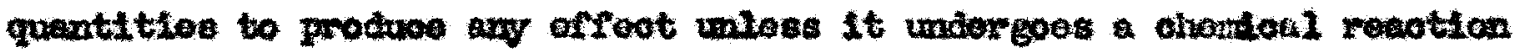
with the sonstluonts in the nood.

Stnee oollulove, tho rajor constituent in wood, 18 very

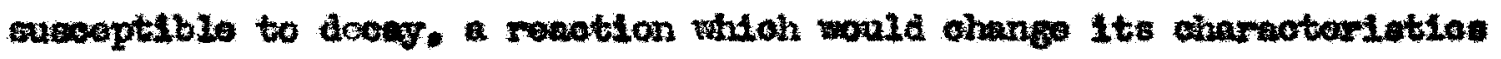

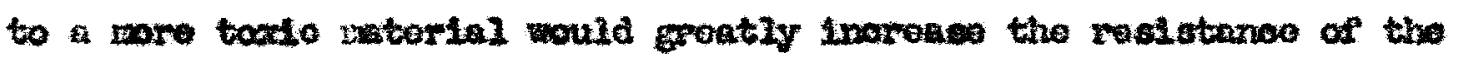
material ae abolo. If this could not bo obtelnod, it is posalble that

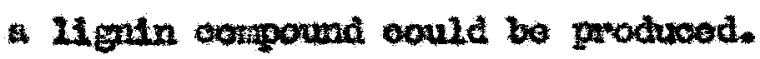




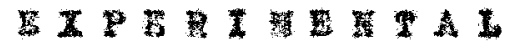


APRATSTS:

The test ohatber was of steol oontrution, 6 inohos indido dianstor. 24.5 lnohes high, externally houted by a gas bumer andor a

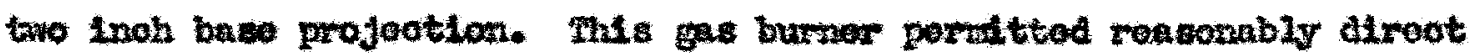

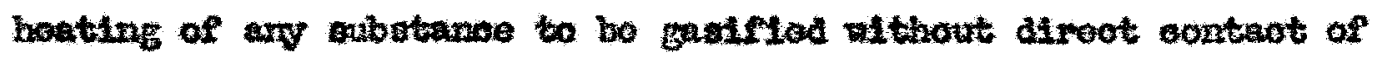

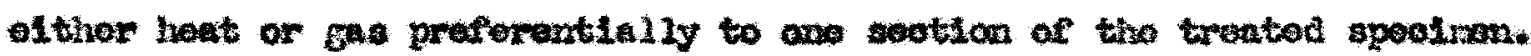

A Fred Carvo: hand operated poss with mumally controllod elootrioally hatod plateno ustas to arro tho aumploc.

4y

Yollow poplar - Mmeo sizes wero uad, 8 inohos long by 3 Iriehes wido, and $0.75,0.35$, and 0.05 inoh thick rospettroly.

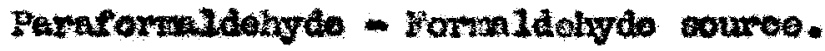

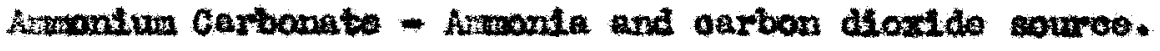
Dry Ioe.

\section{Pooctoum:}

Tho gas generating oubstamos was plaoed in the botton of the

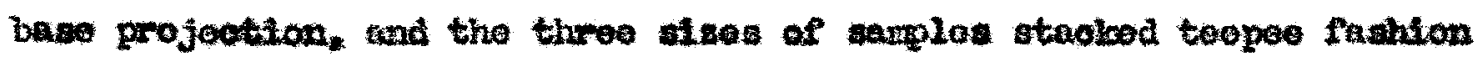

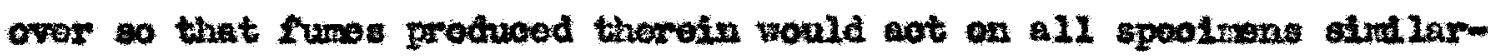

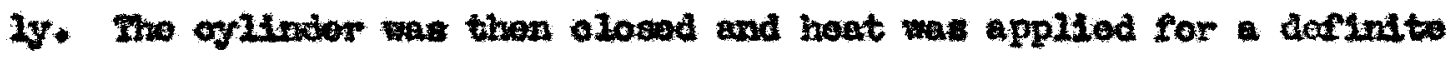
Longth of the after which the vessel mas ooolod, moscure reloased. and samplos rewoved. 
DAW AD ESTLES:

In the first tosts with formaldohydo as tho Irprogating gas. 7 grams of paraformaldatydo per 100 grams of wood woro placod in a tost wabe in the hoating apade; the oflinder was ocaled and the prossuro was

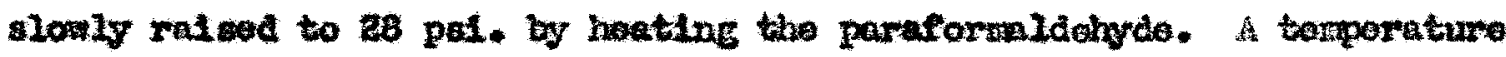
of about $150^{\circ}$. was reachod and indintained for two houra. Aftor tho sanple wat oooled, the pressure was rolonded snd the nood ronoved. Apparently condonsed molotine had oansed a atain on portion of tho

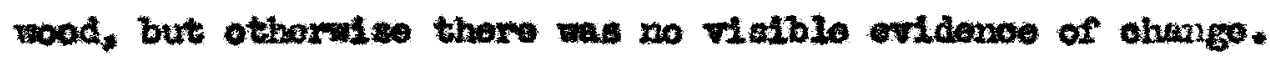
The rolkowing two motho woro usod in an atterapt to detormino ohamically the anount of fommldeinde absorbed or ropotod:

1) The atandard ivtrogan Poraxldo 3xthod for formldohydo solutlons. The colution wood in tooting wex prepered by conkting the troatod wood in a saturated potacsion ohlorate solution acidiflod with nttrie aold.

2) The Fotasatim Dieinemate Procedure. In this mooediwe approxtratoly 5 grams of wood ghavings aro sostcod in a soluthon of 50

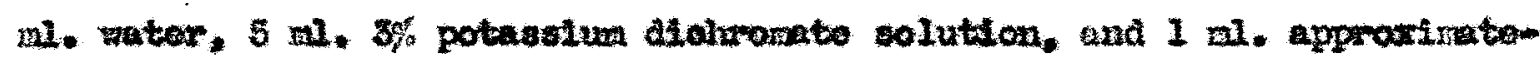

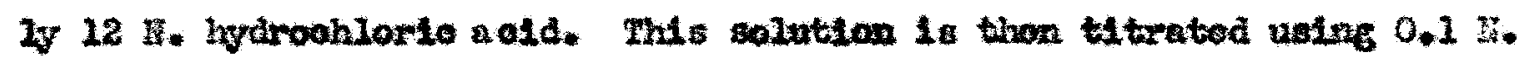
sodiw hrdroxaldo with phenolphthralein indloator.

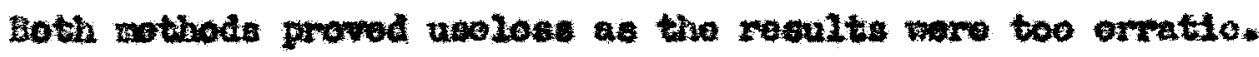

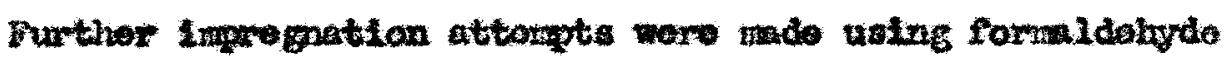

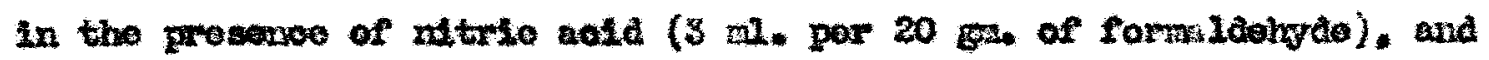
with nitrio acld alono. A asplo of wood also rmo through tho arso 
trontrant without an 1.prograut for control gurposes. In thowe, tosts

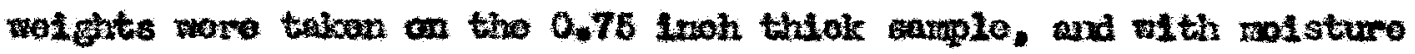

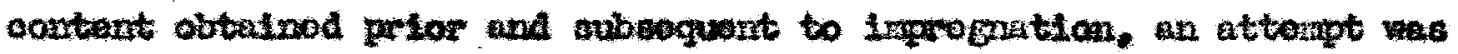
nade to netgin ary gatn.

It w11 bo notod in rablo II that hore was an apreolable Loss in wotght of the wood won heatod in tho oylinder without an

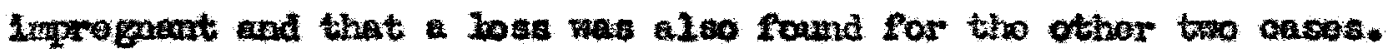

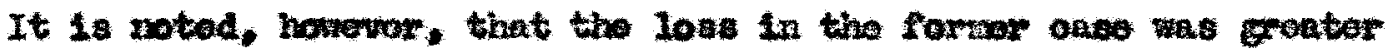
than the latter although to only a all dogreo. This mint inatute

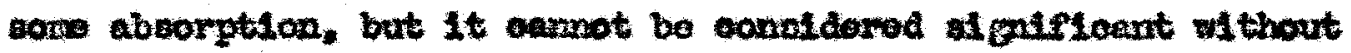
furthor wroaf.

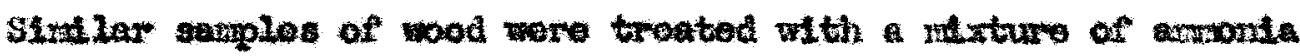

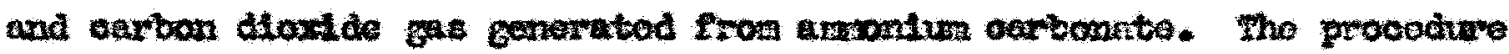

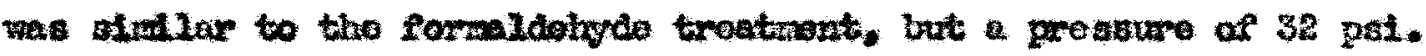

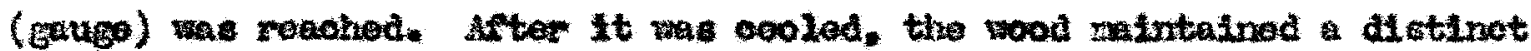

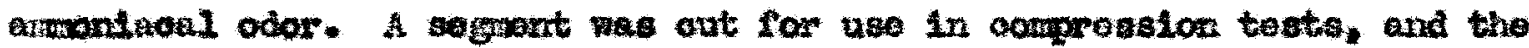

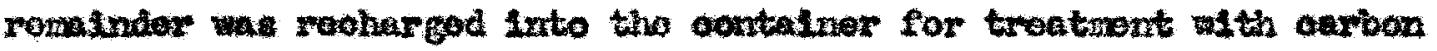

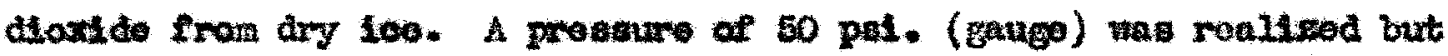
gradually decreaced ovon wh heating bosause a loak doveloped in the

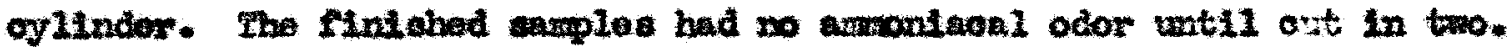
An odor was thon detegtad fron the centor ceotione of the rood.

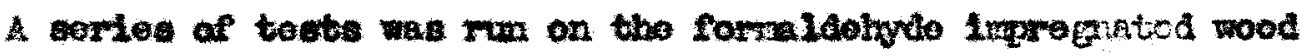
and on the untroxtod wood bo deberrane the rathwe of stabilisation obtainod by prossure and terperatare. It was found that $385 \%$. I $10^{\circ} \mathrm{F}$. and 2000 psi. wore tho roat satfofootory conditlons, and subsoquent 


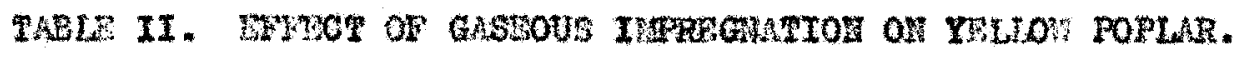

\begin{tabular}{|c|c|c|c|c|c|c|}
\hline moatment & \multicolumn{2}{|c|}{ 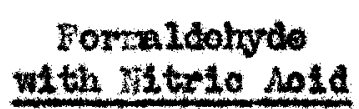 } & \multicolumn{2}{|c|}{ Itroso A010 } & \multicolumn{2}{|c|}{ Control } \\
\hline Inteind Wolgtit & 158.1 & ta. & 188.2 & a. & 143.1 & 6 \\
\hline Solbture contont (i) & 0.79 & & 7.00 & & 5.78 & \\
\hline Dey hexgt & 144.2 & Bat. & 174.8 & gan. & 187.0 & $2 n$ \\
\hline Final rolgt & 160.0 & gat. & 274.6 & gan. & 150.0 & Wo \\
\hline * Wolsturo Contont $(0)$ & 5.91 & & $3,4:$ & & 2.75 & \\
\hline *Dry Wol wht & 148.0 & gan. & 168.7 & Ex. & 132.0 & Ga. \\
\hline lelght oulnod $(t)$ & -1.5 & & -3.6 & & -4.3 & \\
\hline
\end{tabular}

* Values taton after treatrient. 


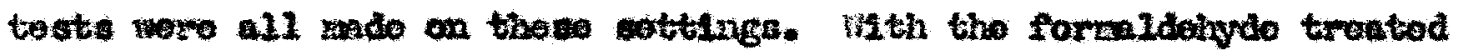
wood, bllaters and explosions ooonrod. Ints Indiogted the pocenoe of wnowoted or unstable products in tho sass and nero probably not

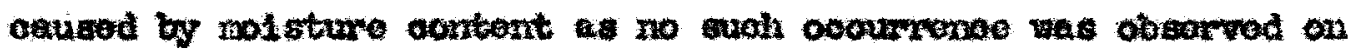

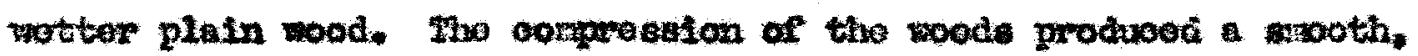
darte brom strface. oonstorably hardor than the orighal and of an

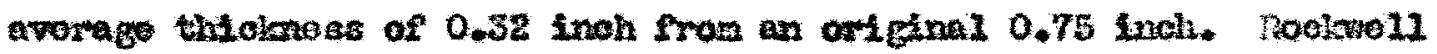

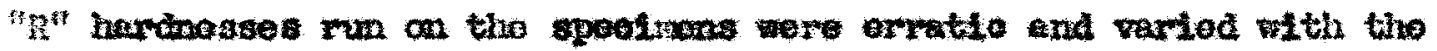
hoartwood-eaprood struoture beyond receonable limite.

Semples af the treated and ocmpresod wood wore irmoreod in abtor for wook in an atteryt to doterndas roletive otability of the producto.

The roaulte tabulated in Foblo IIt chow that in all oagos the troated andes voro more stable than tho untreated wood. II-

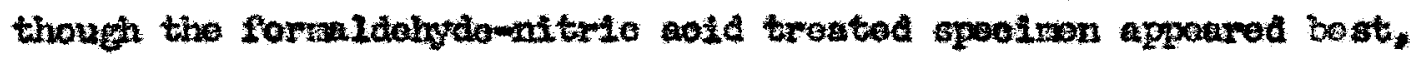

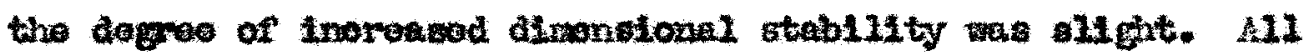

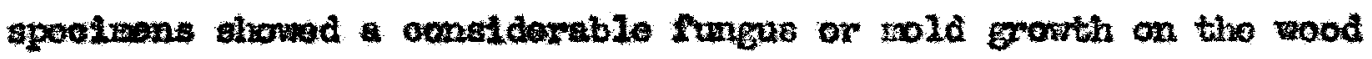
and on the surface of the Indivtanal conkthe satha. The spooton of the fungus or nold was not dotormednod.

toust

Mils prolfidnary investigation Indieatos that formaldohyde

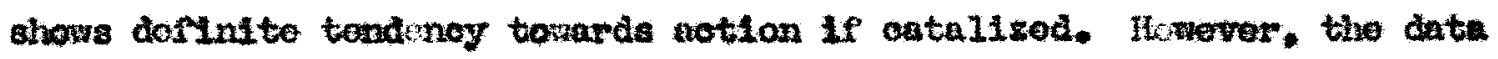
are too mager for any pestutve conolustons.

It Is rocomosded that a mo definite roans of tosting troated anplos be used auch as an exposume tot to wood destroying organsas. 


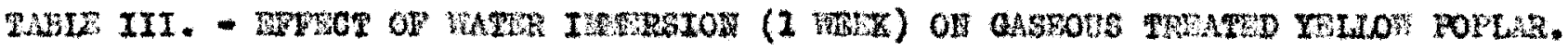

\begin{tabular}{|c|c|c|c|c|c|}
\hline Treatraont & Forma 1 dokrde & $\begin{array}{c}\text { Formaldehyde } \\
\text { yth } \\
\text { 3it tre sold }\end{array}$ & $\begin{array}{l}\text { Mrsonfun } \\
\text { Carbonatos }\end{array}$ & $\begin{array}{l}\text { Anoontiuna } \\
\text { Carbonato } \\
\text { axd Dary Ice }\end{array}$ & Control \\
\hline
\end{tabular}

\begin{tabular}{|c|c|c|c|c|c|c|c|c|c|}
\hline $\begin{array}{l}\text { Orlginal } \\
\text { Thiolmost }\end{array}$ & 0.75 & Inoh & 0.76 & moh & 0.78 & $\operatorname{lnoh}$ & 0.70 & Ineh & 0.75 \\
\hline 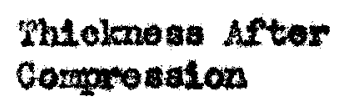 & 0.30 & $"$ & 0.32 & u & 0.34 & $"$ & 0.55 & " & 0.30 \\
\hline $\begin{array}{l}\text { Thiclenoes After } \\
\text { Noek Imanerelon }\end{array}$ & 0.57 & 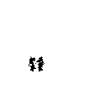 & 0.48 & $n$ & 0.61 & $n$ & 0.64 & $*$ & 0.72 \\
\hline
\end{tabular}




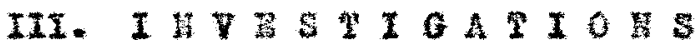

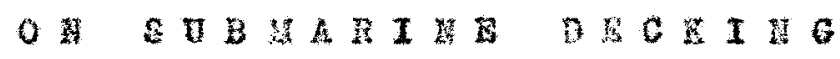

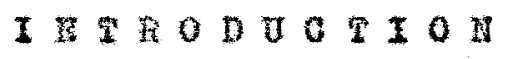


One of the mot important uses of rood on Arerlow subrarines Is In construotion of the superflotal dooking. Swoh oonotmotion is subjooted to sevore hydrostatio prossure izpaota oaused by the dosoendIrg or suraoing of the subartino, and is also subjooted to doeny oncountorod in sea veter.

Therefore to bo a outteble materlal tho wood asst have all the following properties:

a) Rosistianco to prosinuro inpact

b) Noslatanoo to doony

c) Dranetonal atabluty

d) Moar realstanoo

a) Ron-slipplaz suxface onpolally when wot

The mod for the furot popattio has boen rentonod. Dizanatonal stablilty Instros thet fabtoninga, and wear rostatanco

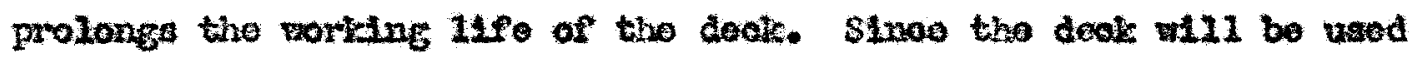

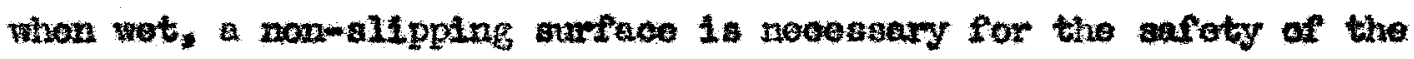
orex.

Teal wood has been found to bo complotely satidfactory. and no abstitutes havo ever been used. Beeause of tho inoroased output of subarines in the past fow yoars, howover, tho aupply of toak has dooreaged to oritioal point.

Irpollod by this sttuation it has boen the ofn of this rosearch to find a substitate whioh will hevo propertios closely rasomiling toak wood. 


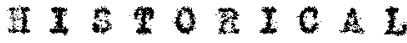


In the part dooado, beaduge of the rert of the Forest Products laboratory, wood has begun to ollnb bacle to tho inportent poattion it hold bofore the porfeotion of setals and plattios.

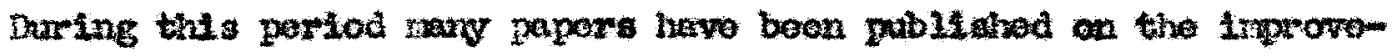

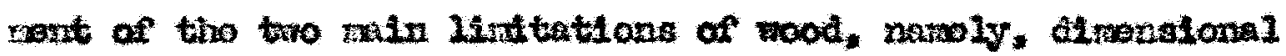
toblilty and dopay rostatance.

Staxn (1) disonseod the effoet of inorganto salts upon tho wolling and shrinling of wood; howover this nothod was not satis feobary, for the lts tondod to leach out.

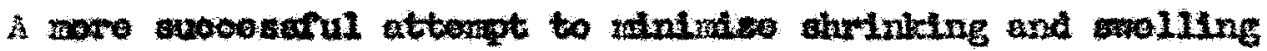
of wood tado by stan and lanoon (2) roplacing the water with non-volatile materials. Wh the use of an intermodiate solvont the

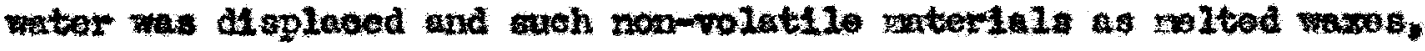
oilv, and reatns wero affuad into tho eoll valls of the wood. Efflotonolos as hit as 80 por cent baged on plain wood controls wore rea11sod.

In the onec remtloned. higt efflolonoles woro nothered booause of a vory groat decroase in the rate or absorption rather than

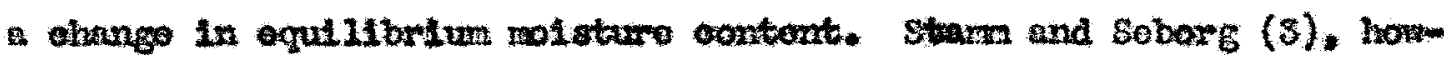
over, changed this ogulubriun by formang symutio rosins whthin the fino enplilary otruature of the nood.

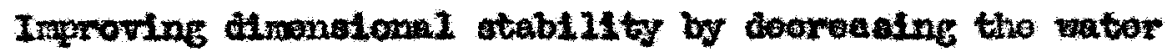
absorption also limproved the rot roskgtenwe sinoo molst wood 10 veny ausoeptiblo to doory. 


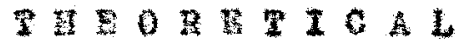


Food is bygrosoopto and, lliso all other fibrous materials, possesees tho proporty of selling and ahrinicing with ohango in hualdity. Feter is beld in the wood in two was inblbed wator in the walls of the wood oolls, and froo water in tho oell oavitios. Whon wood baglns to dry. the freo water leaves first followed by tho inblbed ater. The fiber aturation point is that condittion when all the free whtor has doparted but ell inibibed wator remins. Only below tha point doos wood shrinis of sall upon okange in zoolsture.

The use of a water repollant tatorial woh as wex or ofl

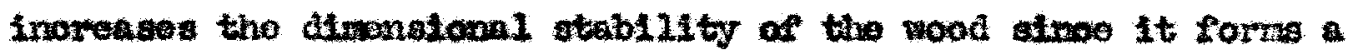

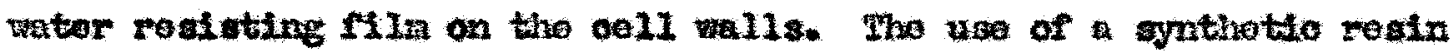

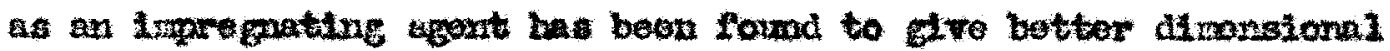
stability. In this mothod a low polgnerized rosin is diffusod into the capillary struature of the mood and wador znoronocd temperature and pressure mado to bind the rino wood strueture into an infusiblo

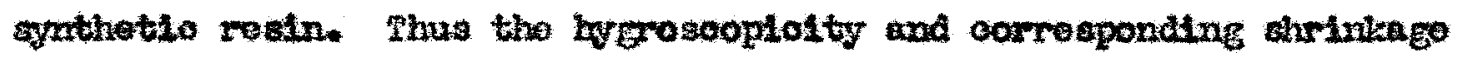
and awolling aro decreased pormenently by ohentoal reaction. 


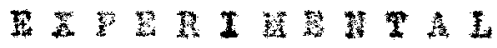




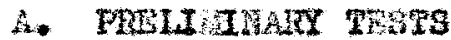

To find a solution to this problera, soxe informetion af the type of mood fallume onoounterve urter actual conditions luad to bo aoquired. Consoquently muber of difierent wods nero subjoctod to strmiated sea concitions and thoir reations notod.

\section{Miangus:}

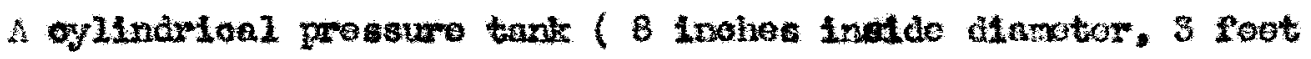

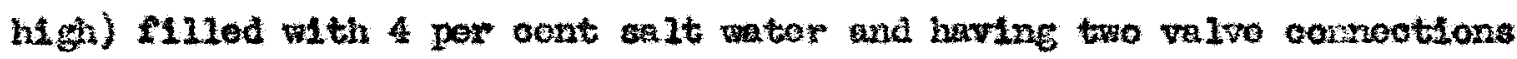
one to an ex omprossor and ono to the atmosphore woro need as a teatm ing onation.

ToDs 4 STM

$$
\begin{aligned}
& \text { Mhogany } \\
& \text { Haple } \\
& \text { Yollow Psno } \\
& \text { Whito oak } \\
& \text { nouglas Ir } \\
& \text { Toek }
\end{aligned}
$$

PuCture:

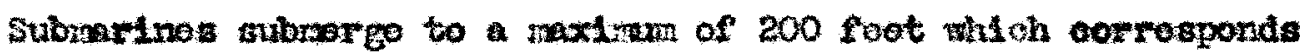
to 68 pai. gauge, and their anoont is rapld boing approxtrately 100 foet por minute. to teet tho wood apoolos effloiontly, it was nocossary to alumlate these conditions. 


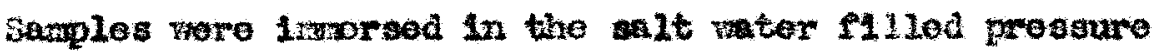
aylindor and pressume ( 85 pal. gango) appllod for 17 hours followed by lradiate release and 7 hours alf arylus at atroephorio presarro. wro arplos woro exposod to 13 such oyelos.

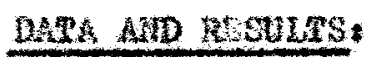

In tho The porous oak. plno, and toak, olight enlargerant of the spring wood pores was poroeptiblo. The photoriorographe of

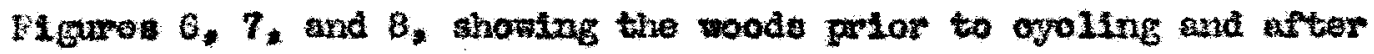

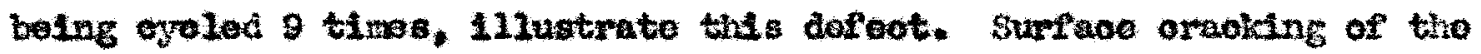
wodullary rays took plave in the whto oak (Fifure $G$ ) and elight warpIng ooewrod in the meplo after the flrst oyolo, but did rot inoreape. III the other untroated wods had no ohongo exoept in wolght and

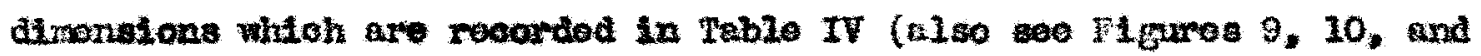

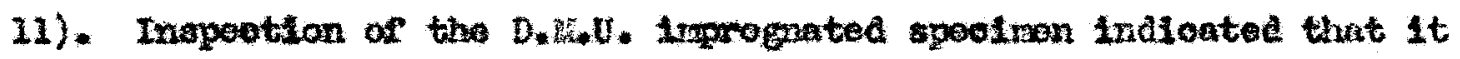

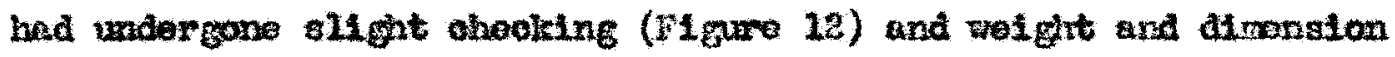

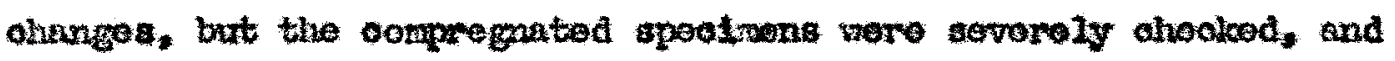

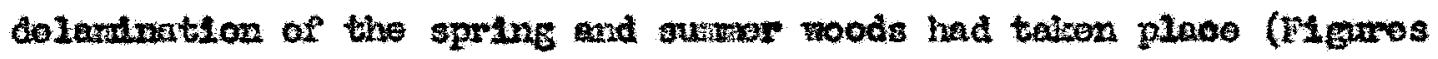
13 and 16).

\section{Decoesruat:}

Tho rasults of the prossure oyolos lndicate that' toak, on tho basts of 1 ts oompratively ma11 wetgt and dinonsion ohanges, is the not aut table materlal. Shogany. though very porous to the salt pater. ghowed very good dimencional stabllity and no otruetural defocts. The yollow plno, dotaglas fir, mele, and 1rmegnatod pine do not com- 
pare favorably wth tho teak and rahogary booave of highor diranolonal

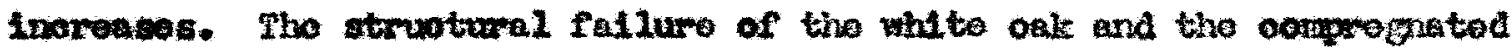
sazaples make thom unauted for the partloular noe. 


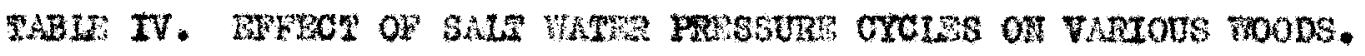

\begin{tabular}{|c|c|c|c|c|c|c|}
\hline Speotimon & $\begin{array}{r}\text { ofgt } \\
\text { (on.) }\end{array}$ & $\begin{array}{c}\text { Cross seotion } \\
\text { Otrongtons } \\
(\text { In. })\end{array}$ & $\begin{array}{r}\text { ost } \\
\left(0 n_{1}\right)\end{array}$ & $\begin{array}{l}\text { weight } \\
\text { gain }(6)\end{array}$ & $\begin{array}{c}\text { Eroas Sootsan } \\
\text { Dimanoloma } \\
\text { (Int) }\end{array}$ & $\begin{array}{c}\text { Aroa } \\
\operatorname{Des}(\mathbb{n}) \\
\end{array}$ \\
\hline Who gay & 101.8 & $1.90 \times 1.46$ & 229.0 & 125.0 & $1.90 \times 1.45$ & 8.0 \\
\hline Iaplo & 247.8 & $1.65 \times 1.01$ & 264.0 & 70.8 & $1.05 \times 1.72$ & 12,7 \\
\hline Tellow Pano & 128.7 & $1.60 \times 1.00$ & 213.4 & 65.8 & $1.50 \times 1.50$ & 21.9 \\
\hline thit to oals & 127.8 & $2.21 \times 0.04$ & $134: 0$ & 52.4 & $2.37 \times 0.98$ & 11.5 \\
\hline Douglas Fix & 54.2 & $2.96 \times 0.75$ & 220.3 & 102.0 & $2.15 \times 0.79$ & 15.8 \\
\hline Toak & 68.5 & $1.95 \times 0.76$ & 100.0 & 57.6 & $1.09 \times 0.79$ & 7.4 \\
\hline $\begin{array}{l}\text { D. H. U. Improg } \\
\text { natod rollew } \\
\text { Plne }\end{array}$ & - & $2.00 \times 0.75$ & س & - & $2.12 \times 0.78$ & 18.0 \\
\hline $\begin{array}{l}\text { D. M. D. Com } \\
\text { pregnatad } \\
\text { Yellora Plno (25) } \\
\text { Composed) }\end{array}$ & m & $2,00 \times 0,70$ & سنستس & سنسيسمست & $2.20 \times 0.72$ & 11,5 \\
\hline 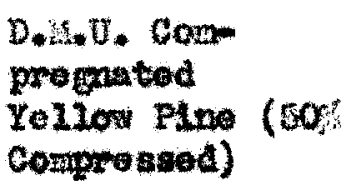 & س & $2,00 \times 0.45$ & (2) & & $2.05 \times 0.63$ & 20.7 \\
\hline
\end{tabular}




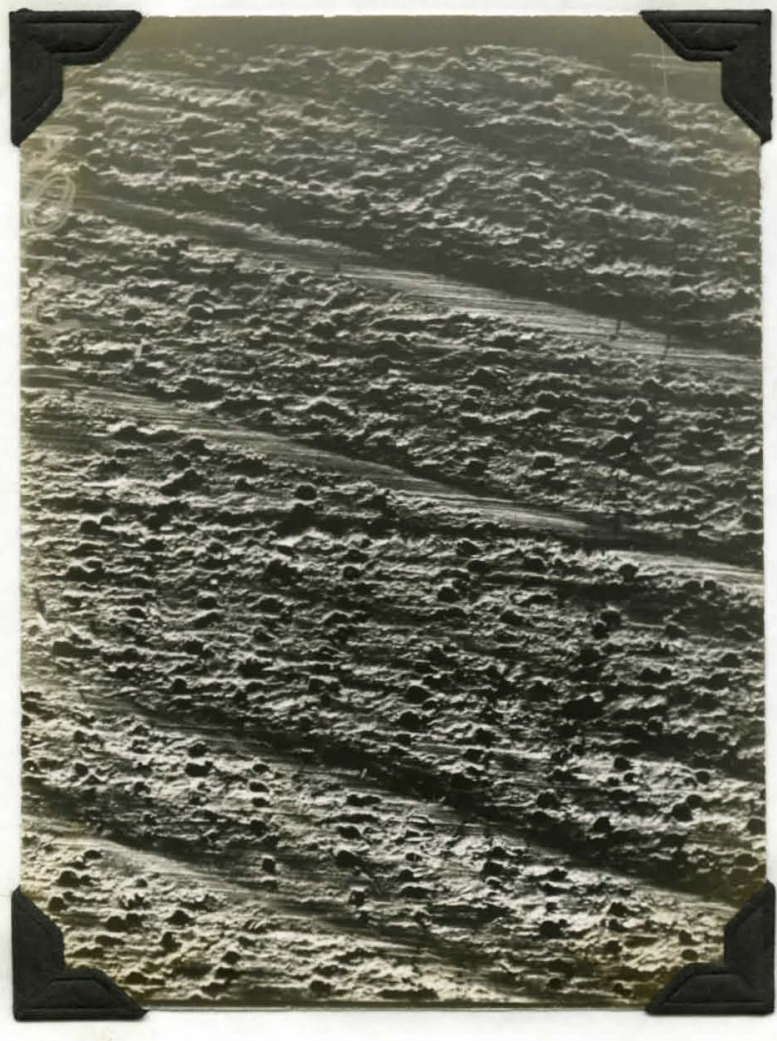

a) Original.

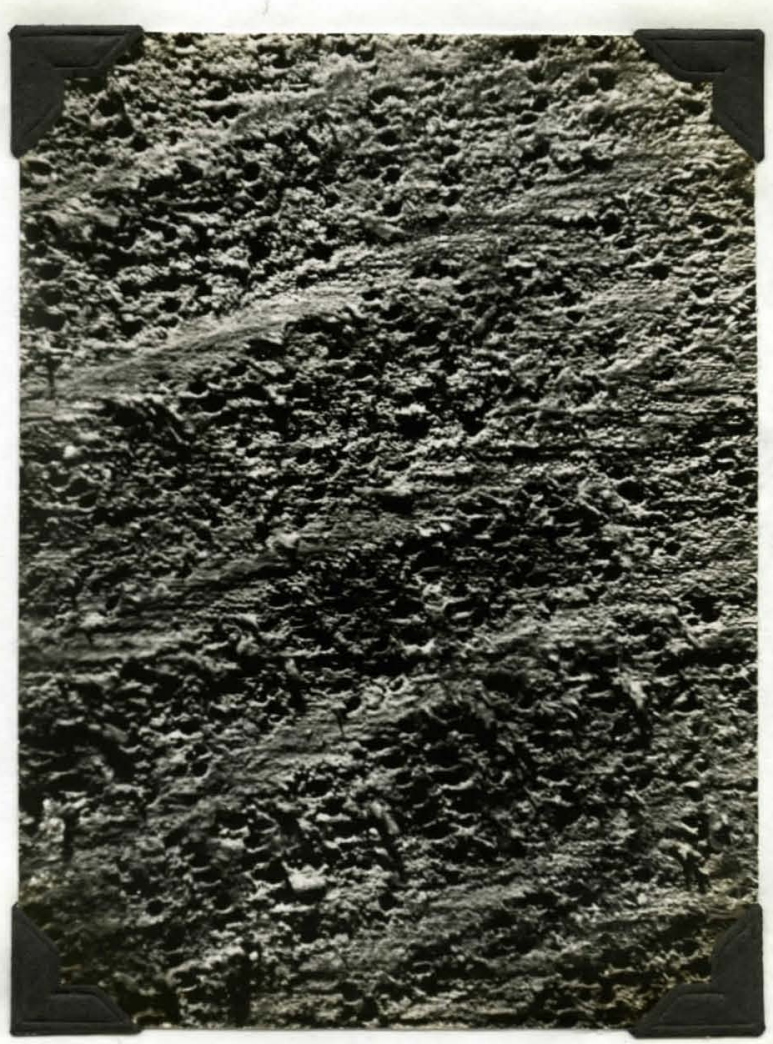

b) Aftor $\theta$ Salt water Prossuro Cyoles.

Hig. G. Cross Section of vanito Oals (ninge EX). 


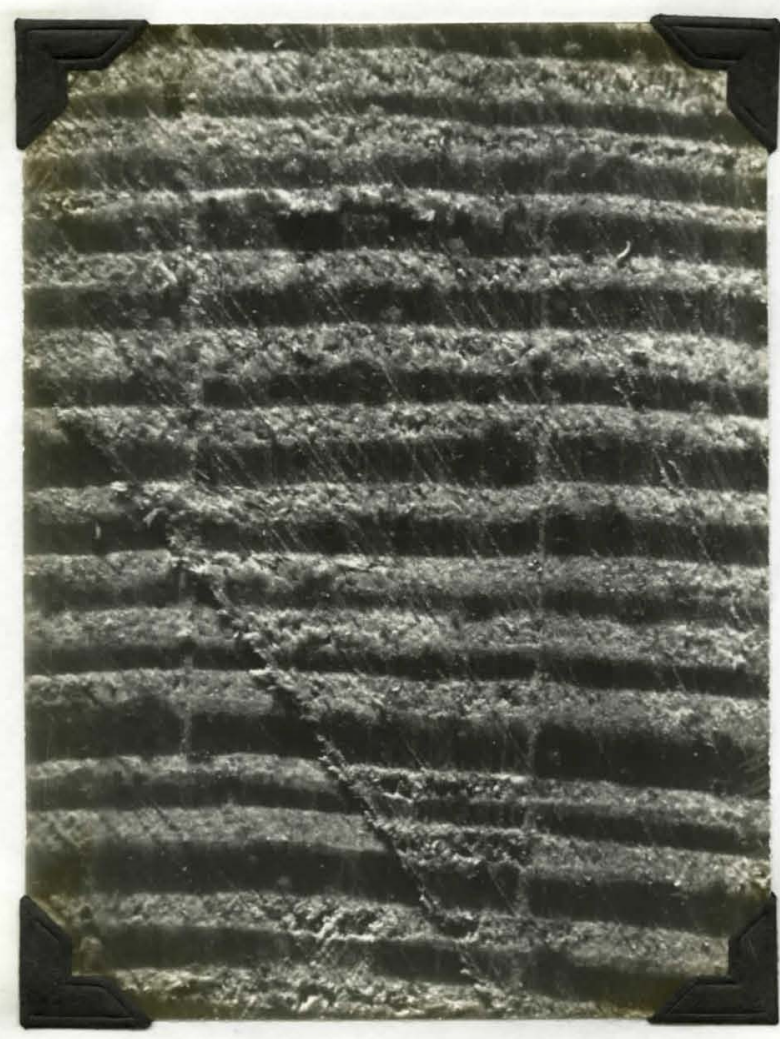

a) oraginea

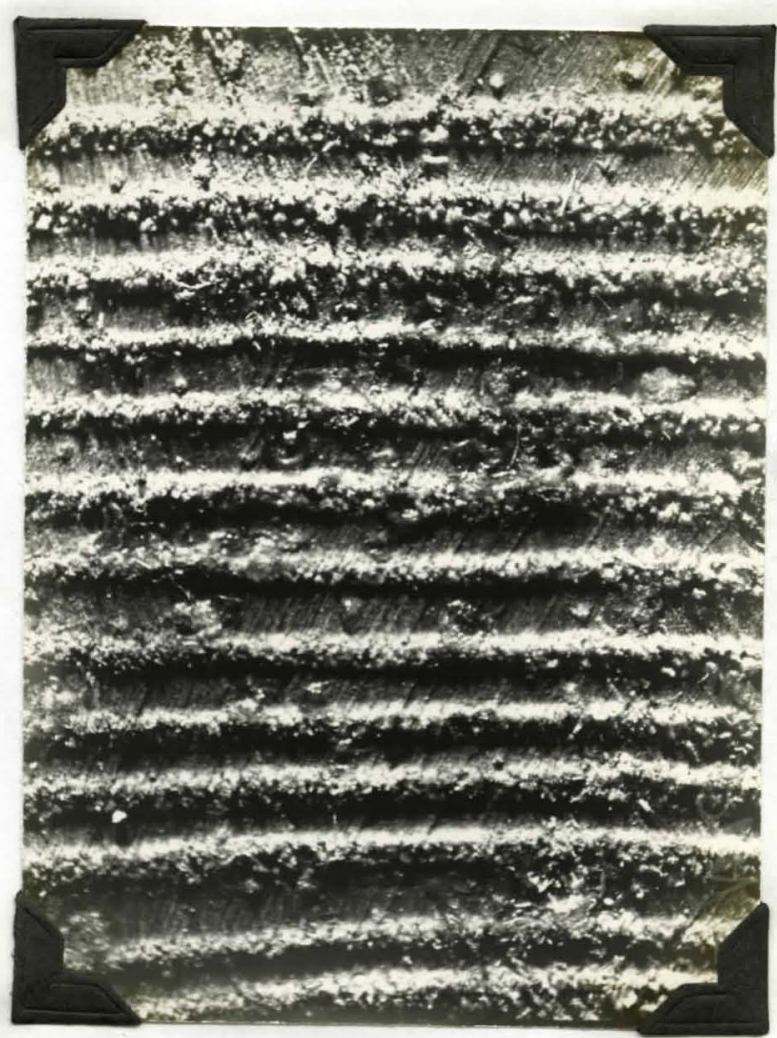

b) Aftor 9 Salt Niter Prosturo Gyclos,

Fig. 7. eross Section of Yollow Plno (Mage 5x). 


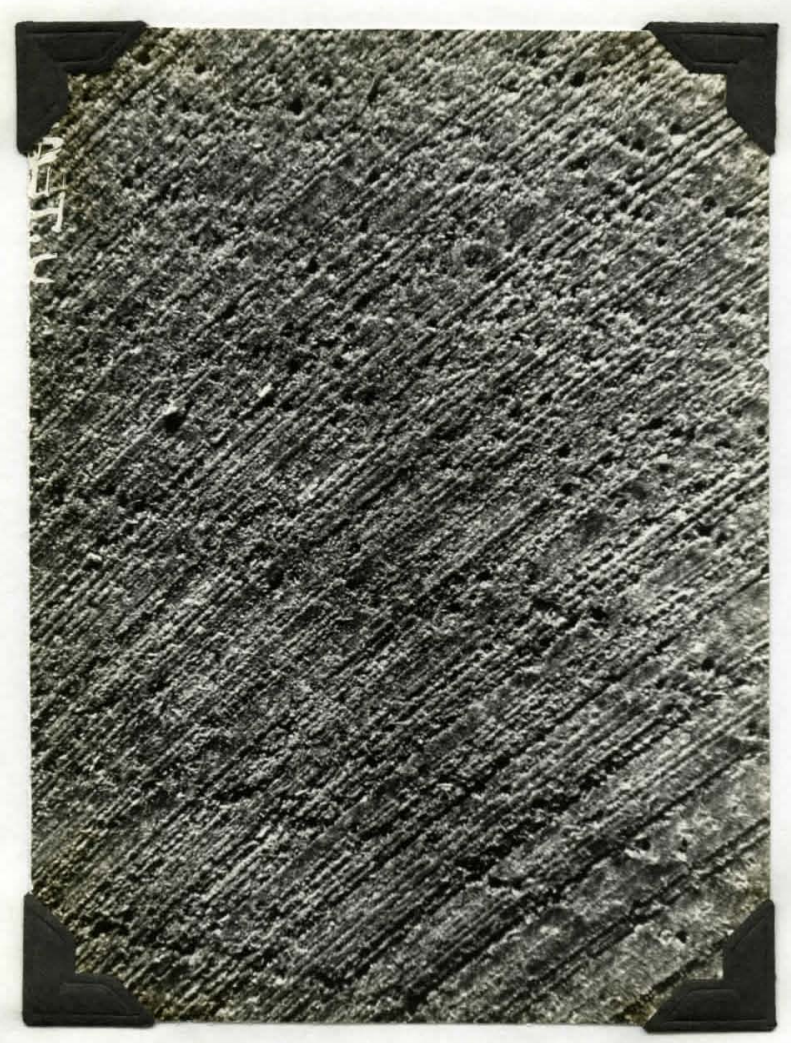

a) originn 1

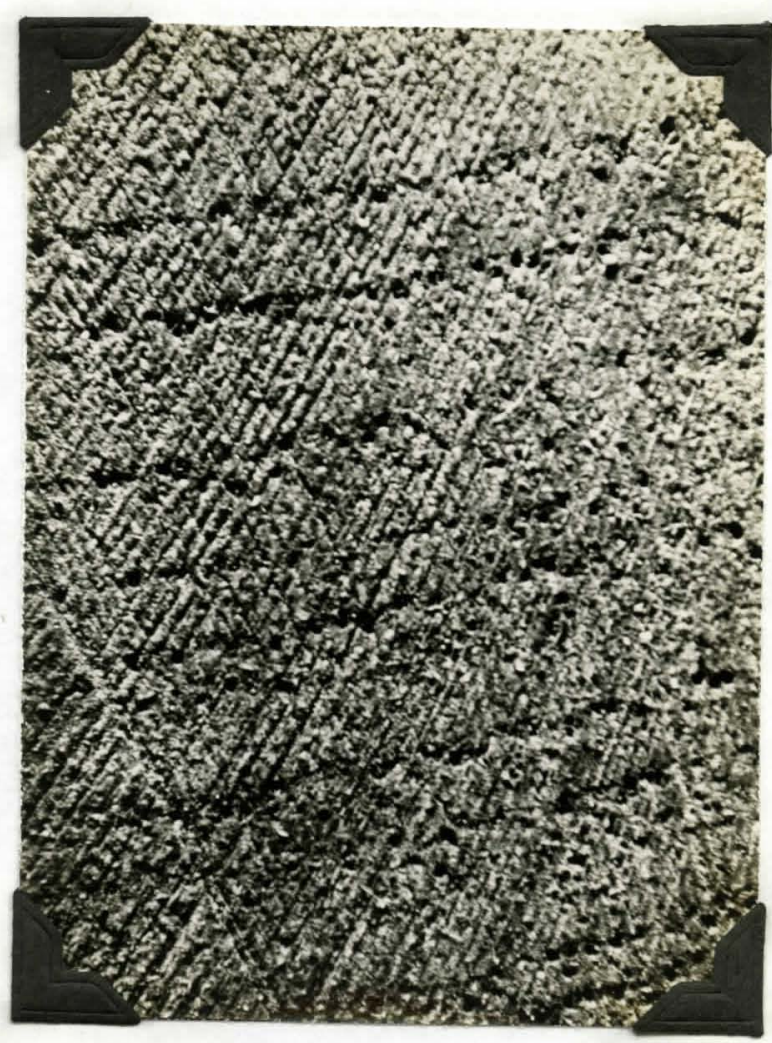

b) After 9 Salt nator Prossure Cyolos.

Fig. 8. Cross Sootion of Feals (Mag. 5x). 


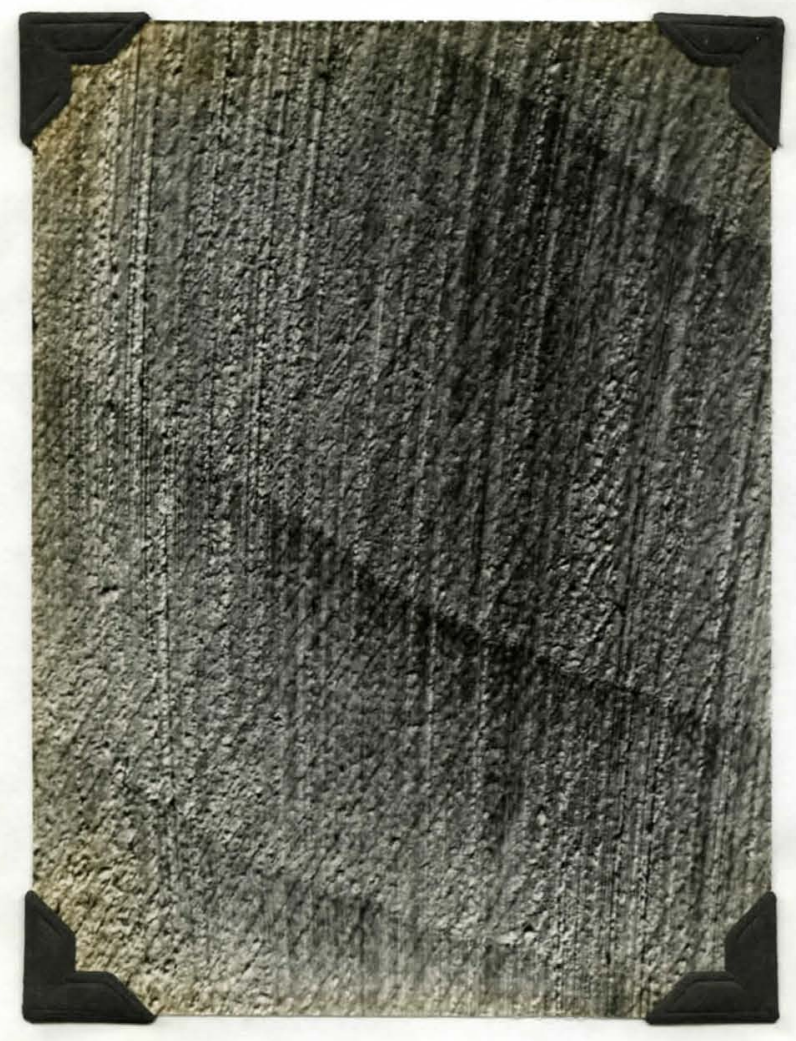

a) origanal

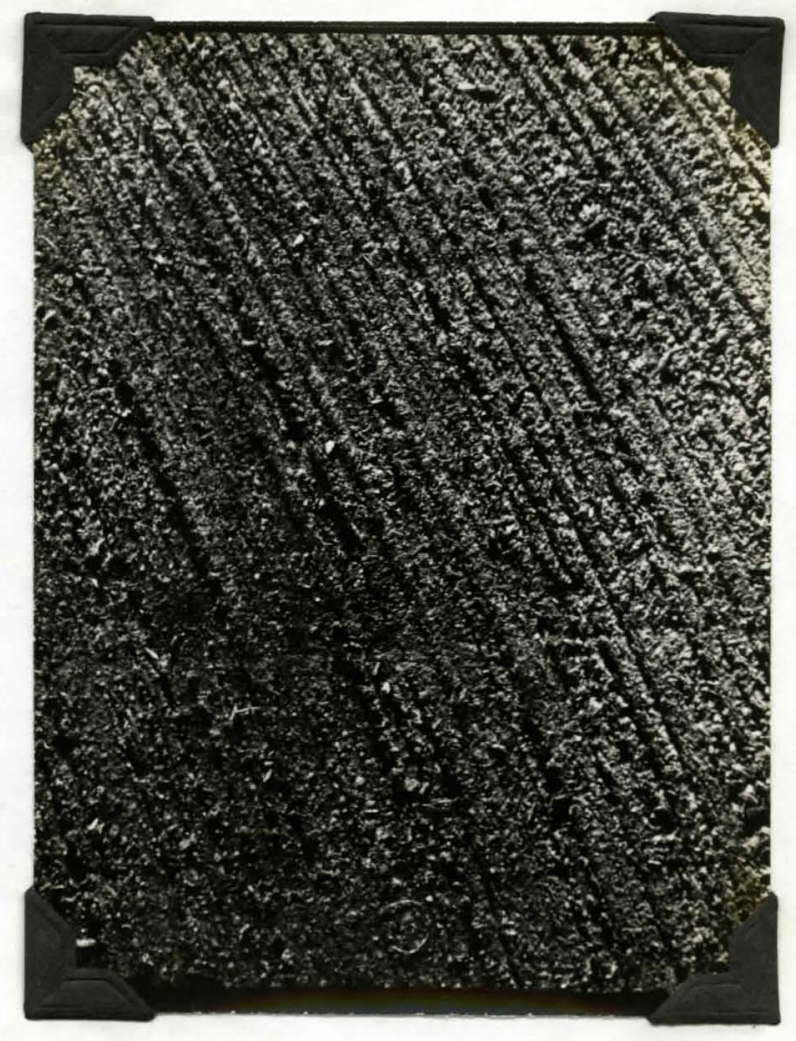

b) Aftor 9 salt thator mossure Cyolos.

Fig. 9, Cross section of tiaplo (tiag. 5x). 


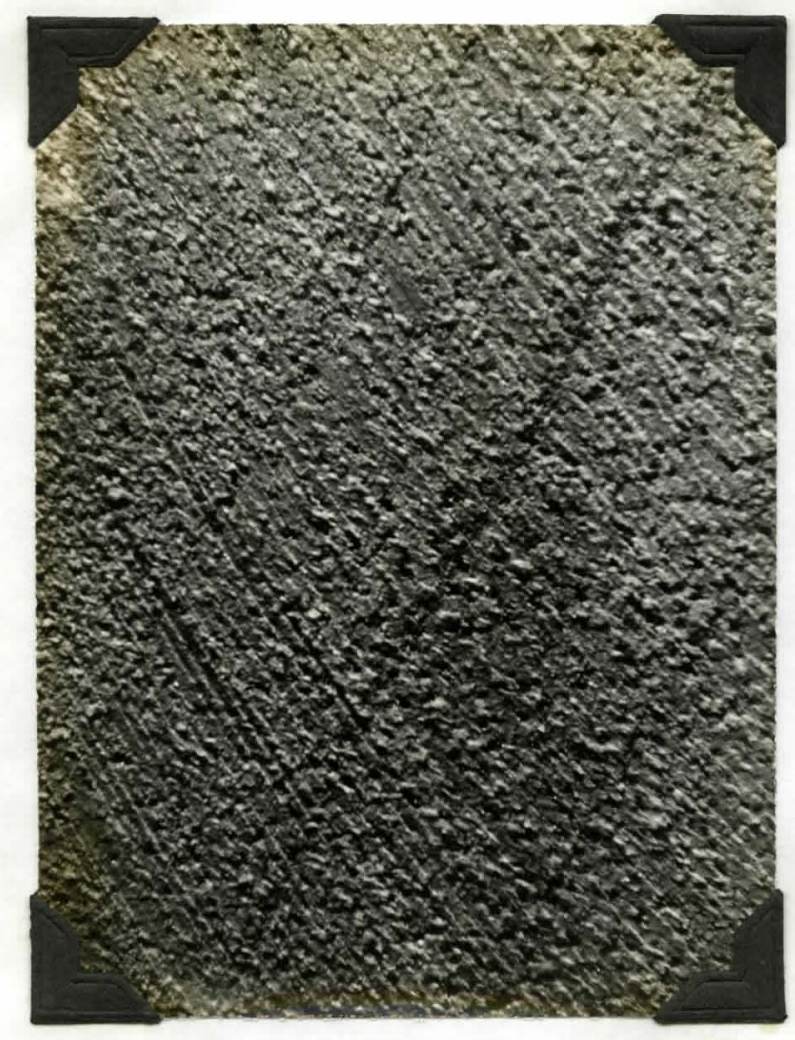

a) Origtral.

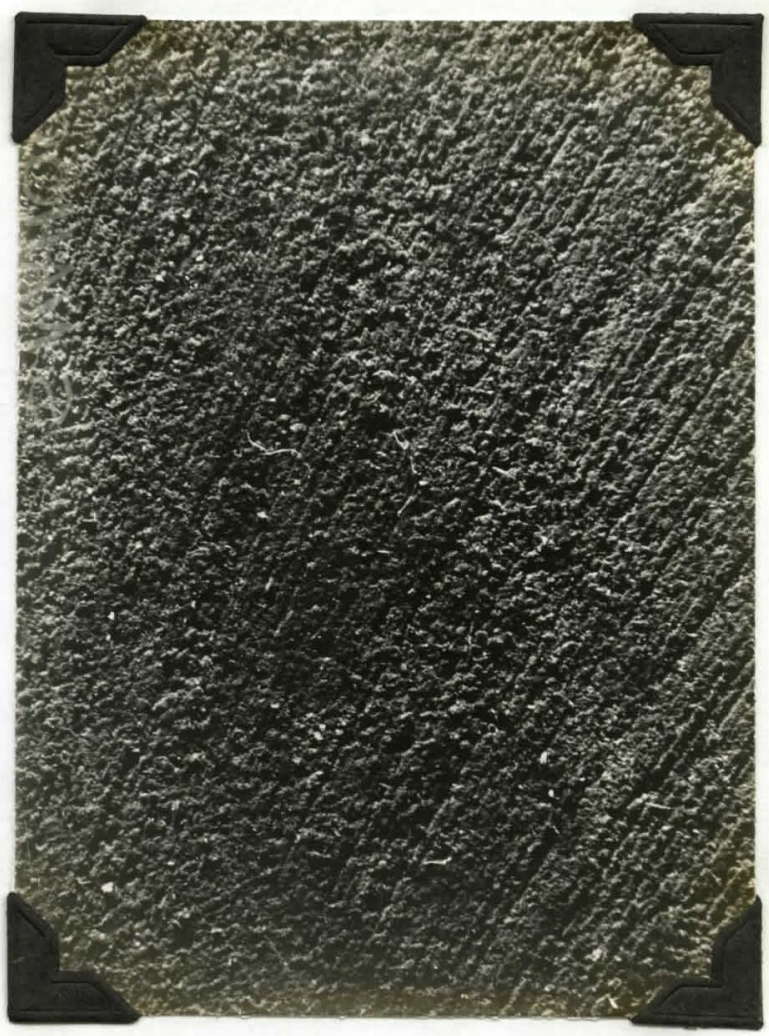

b) APtor 2 salt whator Irossure Cyoles.

Fig. 30. Gross Sootion of hahogary (Hag. Ex). 


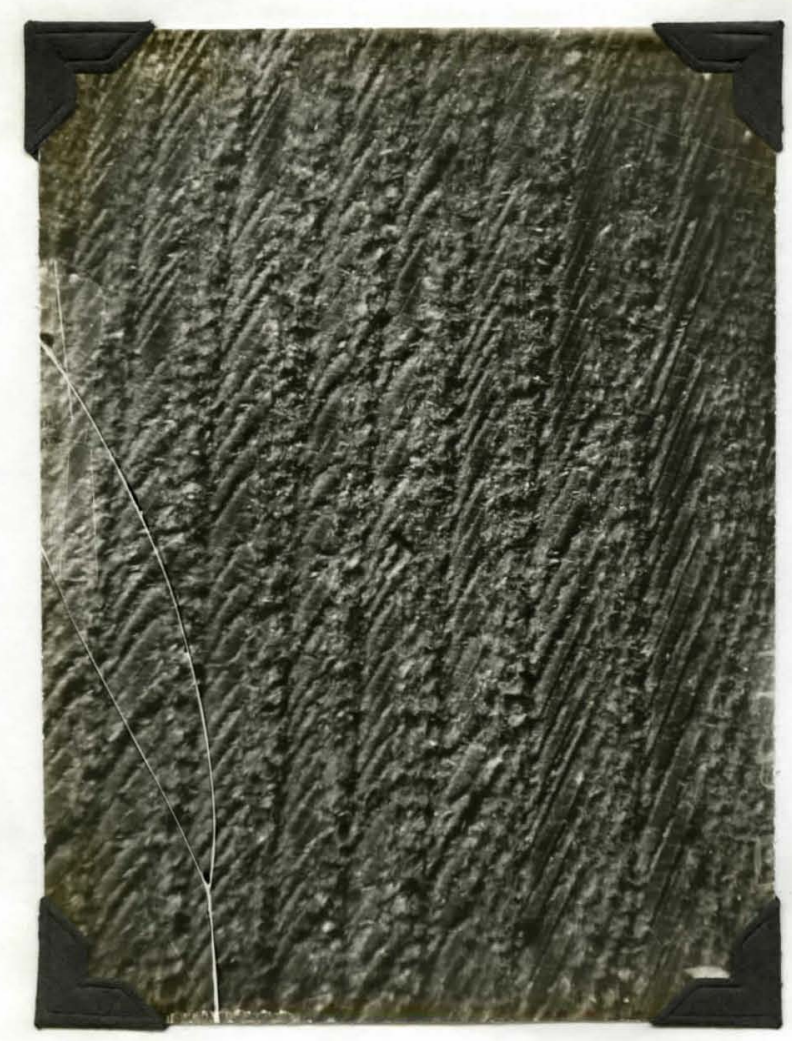

a) origuna.

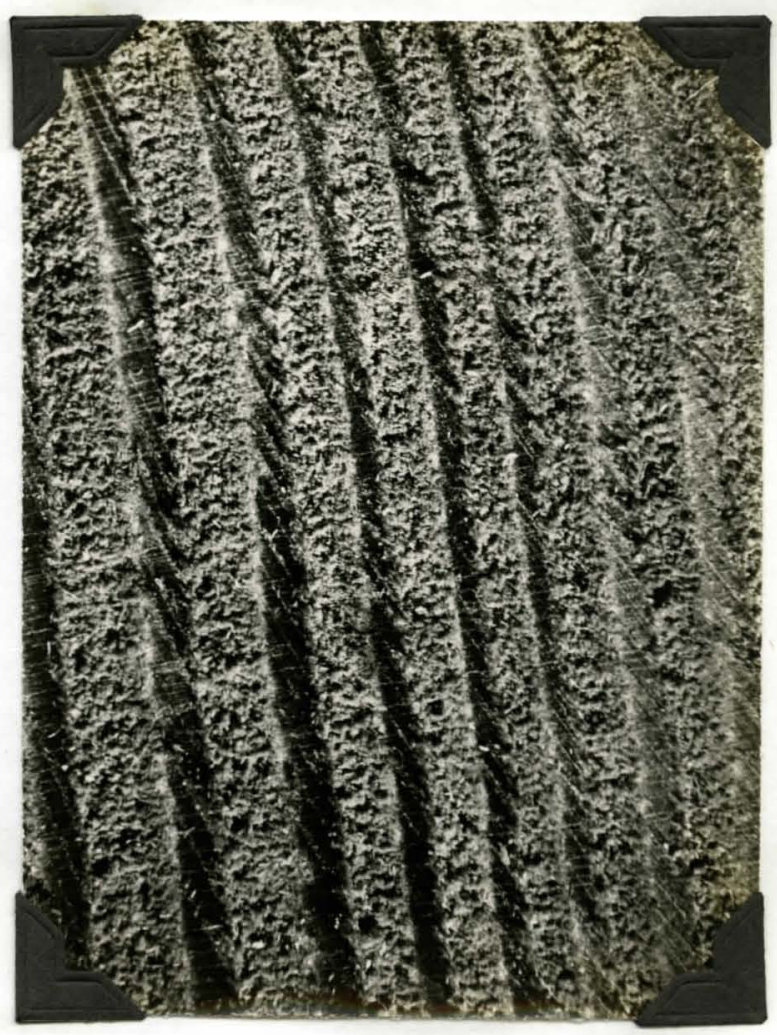

b) After 9 Selt wator Prossuro cyolos.

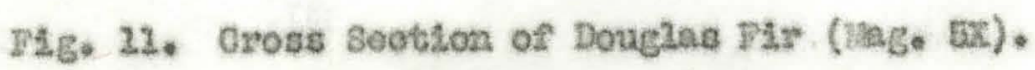




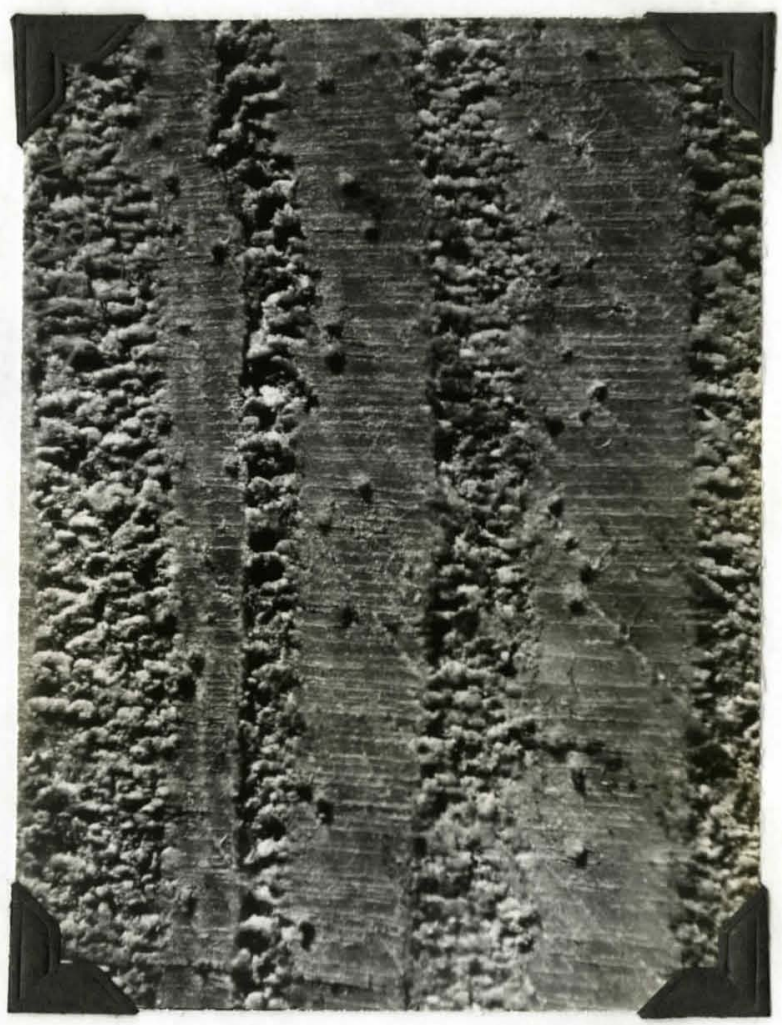

Dig. 12. Cross Section of D.M.J. Impregnatod Yei2ou Pino Aftor 9 salt water Preseure Cycles (Ilag. Ex). 


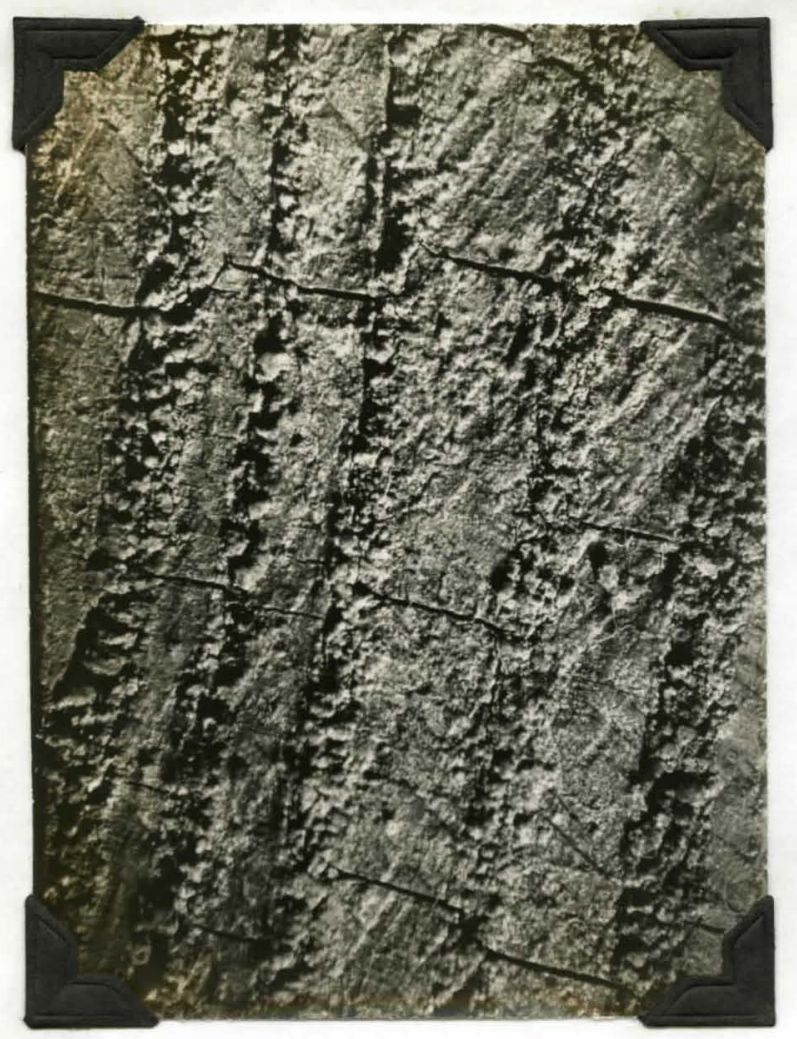

WIg. 23. Cross Seotion of D.II.V. Comprognatod Yellow Mano (20\% Comprossod) Artor 9 selt thator Prossuro Cyelos (Mag, 5X).

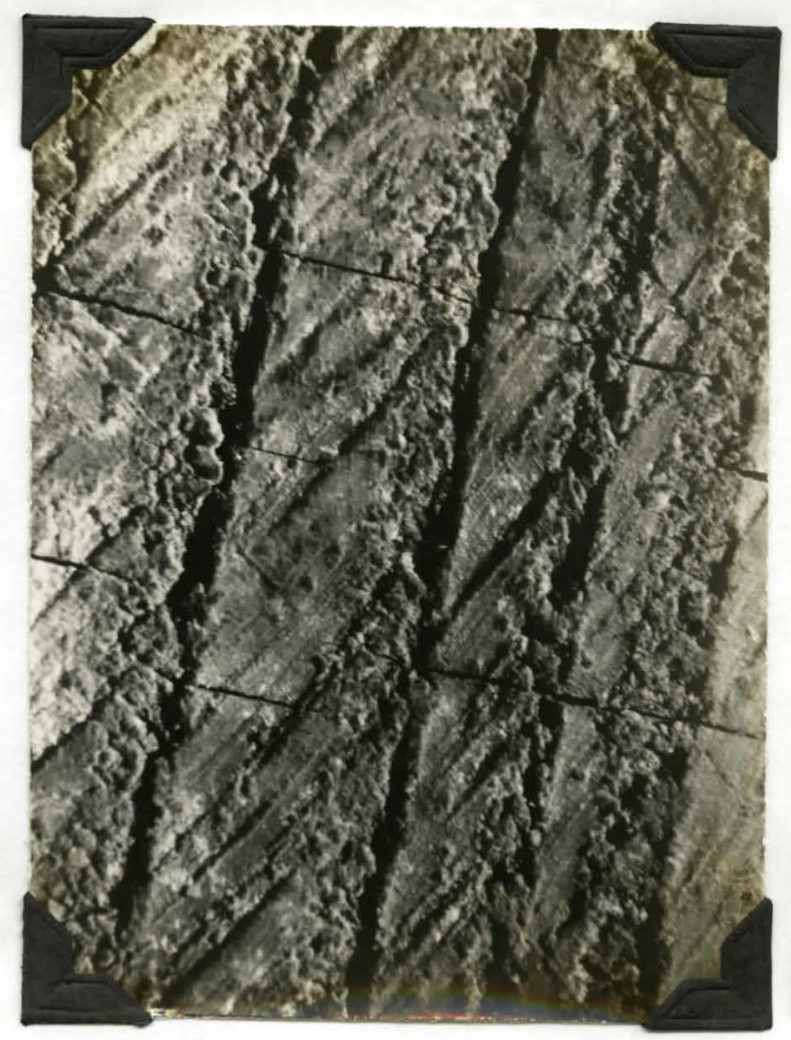

Fi. . 14. Cross Seation of D.H.t. Commognatod Yollon Plno ( 50 ; Commessod) Aftor 9 salt Wator Prossure Cyolos (Ing. $5 \mathrm{X}$ ). 


\section{EXTHZDED TPETS}

From the proliminary tosts 1t was chom that of the woods

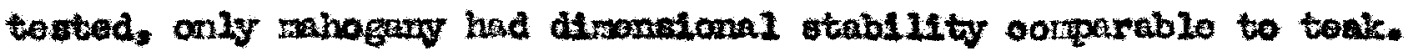

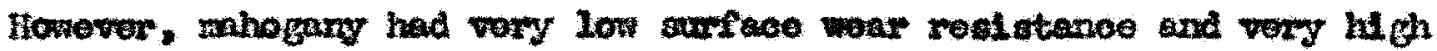
vator absorbenoy. Thoroforo to bovone a sultablo toalk nood aubstitute those undestrable oharaoteristios had to bo ollininated or loabened.

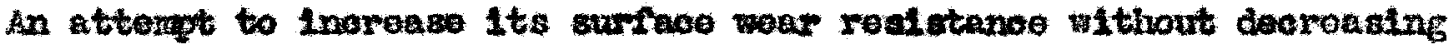
dimenstonal otablitty was ado by isulnating bard iaplo voneors to

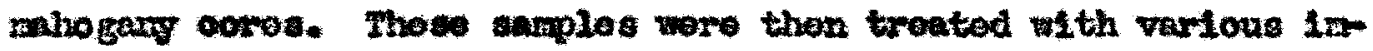

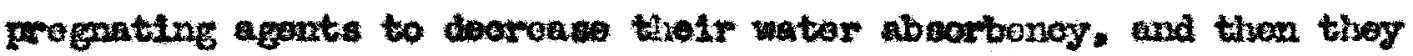
were subjootod to the presanu oyolos. Wabogay and biroh samplea wore aleo troated and abjeoted to this oyolo.

APARATUS:

A stainless steol bueicet and steel prossure cylinder (6 inohes Inslde dianotor. 24.5 inohos $\mathrm{hgh}$ ). oxtemally heated by a gas bumer undar a 2 inoh baso projeotlon, wore used fo: iraregnation. Wests were oarried ont in the proasure oylindor desoribed in the prollininary tests.

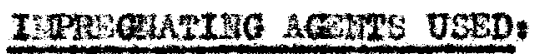

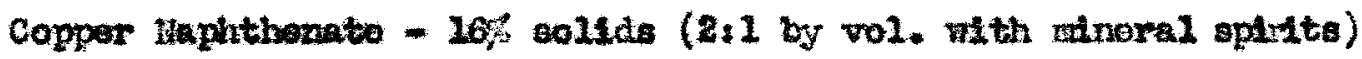
Fos Sealer - (1,2 by rol. with matral spirita)

Bollod Lnsood o11 - actd roflnod (1.2 by vol. 4th turpe ntase) Parapein 011

rung 011 - raw $(1.2 \mathrm{by} .02$. with alnoral spletts)

01010 Aold - (1:2 by wol, with turpontine $)$ 
MOODS ARATH:

hogang

Buroh

Ianinate - mahogary ooro (1 Imoh thlok) with maple feces (1/10 inoh thiok)

Paoctort:

tood samplon (approxluntoly $4 \times 3 \times 1$ inoh) woro plaoed in

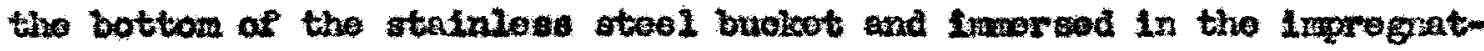
Ing agent. The buaket was then larexod into the lmprognating oyllnder and held under a prosewre of 85 pol. (gauge) for bowrs with hoat belng applled for one of thope hourd. Thon the proasure was alots

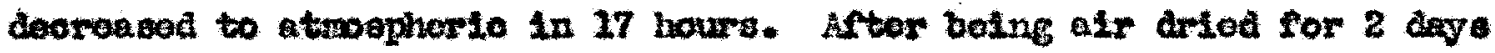
the opoelmens woro subjected to the Balt water prosano oyolos, 1.0. 1moorsed in salt wator wdor as pst. (gauge) for 17 howrs followed by 1zarodiate roleaes and 7 hours afr dryinc at atrosphorto pressure. Hnoh sample was subjectod to the oyoles untll no further weight and dironalon inorease could bo detroted. Controls of the three vooda wore a1so rum.

DAPA AND NESUTIS:

Controls: the matroatod mahogary, btroh, and lantrate (oomposed malny of mohogray) ghowed a Eoator affinity for alt wator than toak as oan be seen by Figuro 15. Fowover Almonstonal stabi21ty of the mogary and laminto oompared favorably vith teak (Figro 26). Tha was in olose agroozint ofth the results of the preliminary tosts. 
Fablo $V$ shows the peroontage piolup of the varions woods upon Impregation. Tho gtokup of tho tumg oll samples was considorably 10 s that the othore.

Appoaranos. All troatod blroh samplos surfaco chookod upon oyoling. Ilowever this did not ooour in the biroh oontrol or any of the other saxplec. A whlte axy subatanoe extmudod fron the oloto acld troted wode after eoch oyele. The coppor naphthasuto also

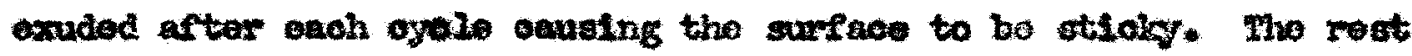
of tho broated samples wore $\$ 14 \mathrm{gth}$ ty ofly reserbling toak wood.

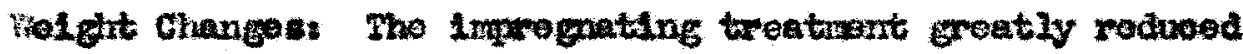
the rygrosopplatty of tho woods and in all oabso lowerod the maximu values below that of toak. Higures 16, II, and 18, based on the

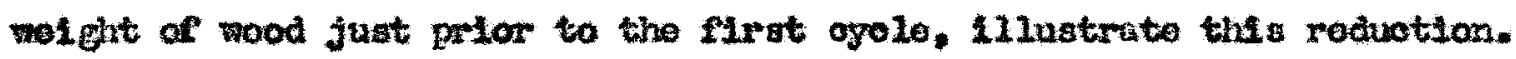

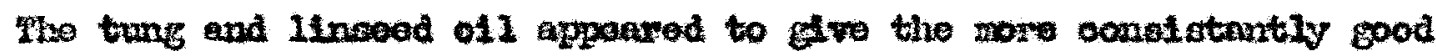

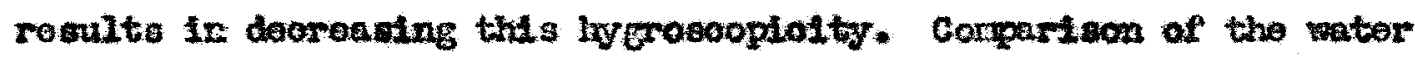
absorbing propertice of tho individal woods troated with the same

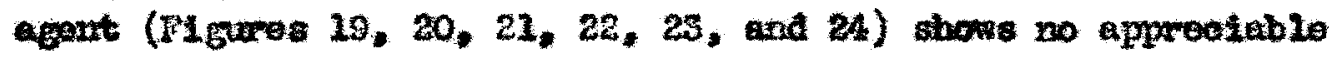
Afferense ange the tixeo.

Dimonatonal Changes: Discounting the troated biroh ourplos beocuse of thoir ohooks. all the Impregnating agente but tho olelo acid

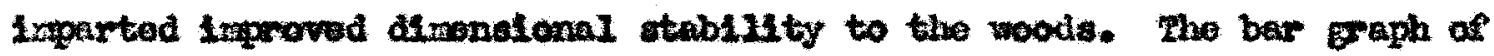

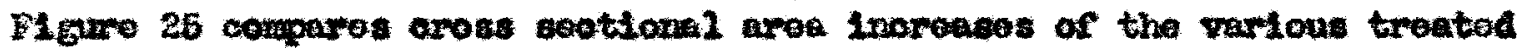
serples to these of their oontrols. Whogary. Inherent2y a stable mood. shomed the bost atability in al1 but the parafrin oll tronted. Dinenatomal gtablilby of tho oontrol laninato, though not so good as magany, 


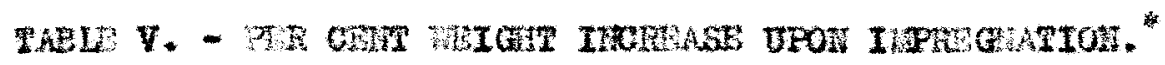

\section{Ienceprating Agont}

Copper Haphthenate

Rez Soaler

Lneeed 011

Parafein oll

Tane 011

oleie Aosd

\section{Iahopary}

36.7

25.2

42.1

$56 \cdot 2$

9.0

49.0
Buroh

Lezrange

38.9

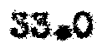

22.0

58.6

19.0

47.0

45.0

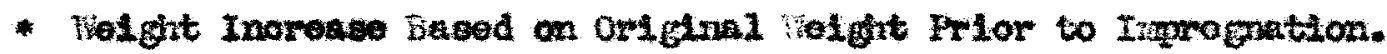




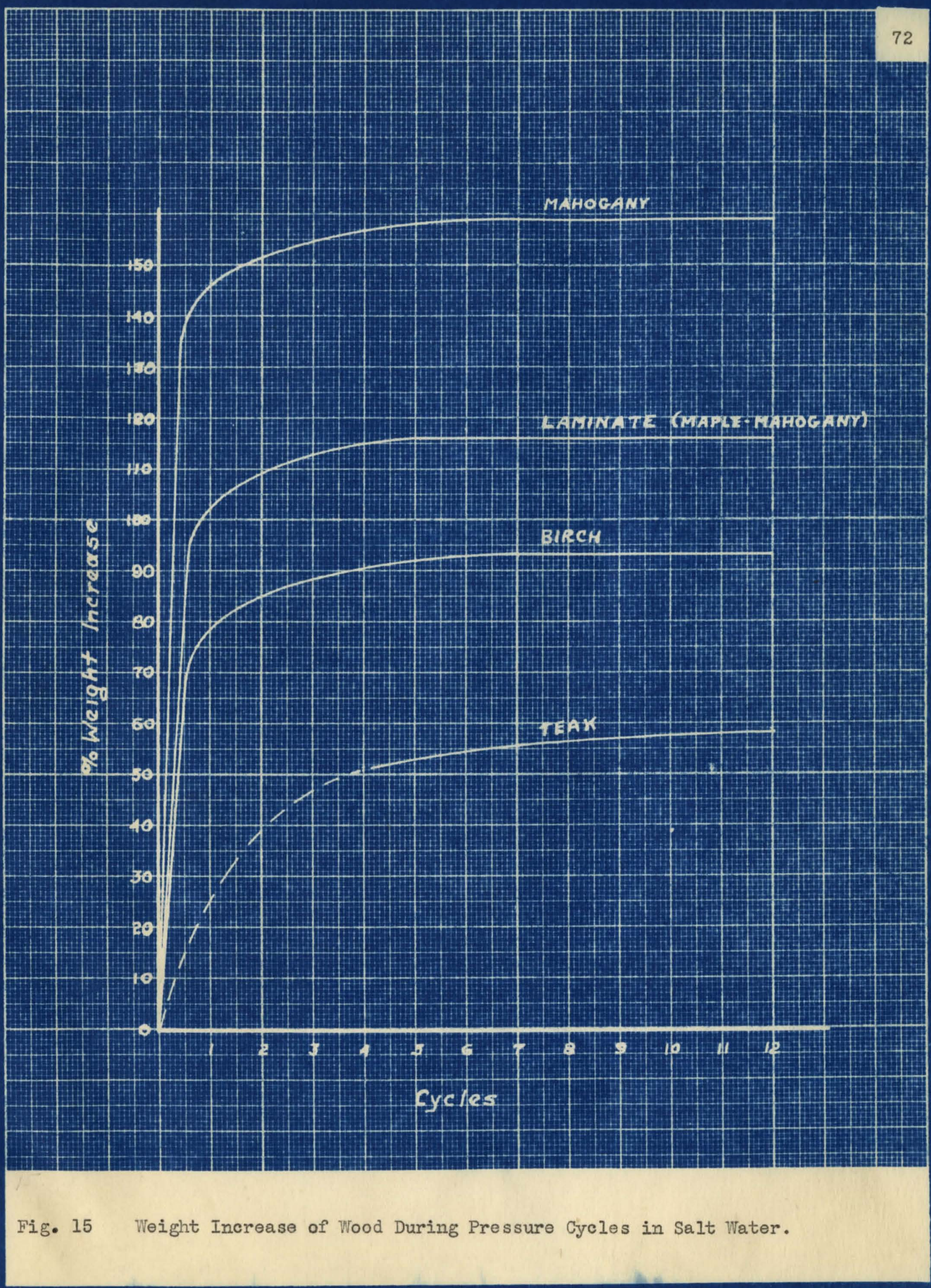




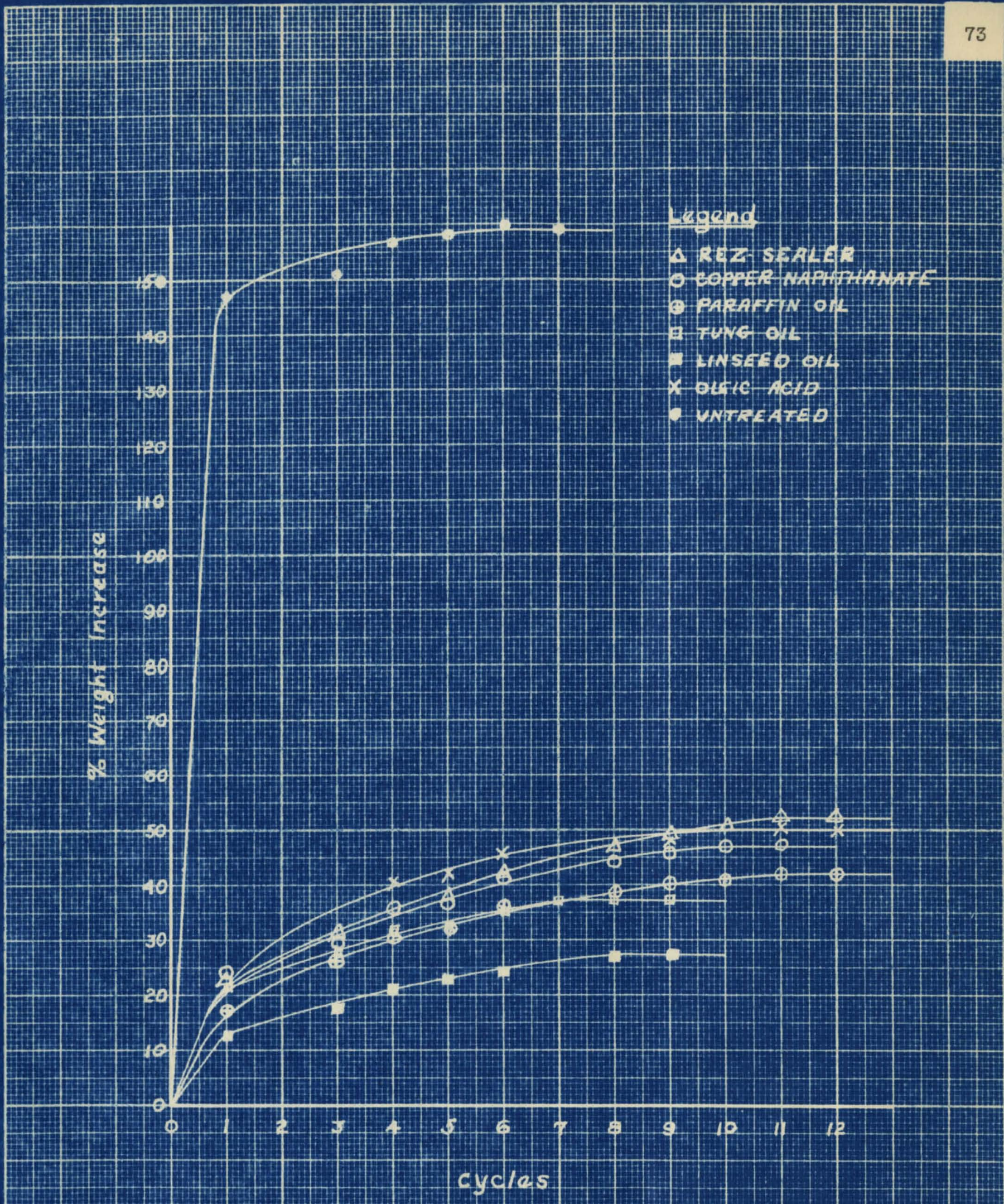

Fig. 16 Weight Increase of Treated Mahogany During Pressure Cycles in Salt Water. 
comparod favorably with wak, and all its treated anmles showod still

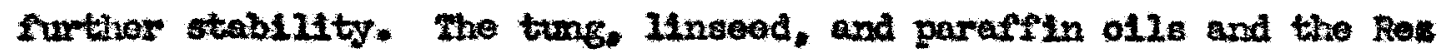
Sealor siloved the bet results in roduolng dimonatonal ohangos. The coppor naphthauta, though lnoreaslng the stabl11ty of rahogary. Gevo

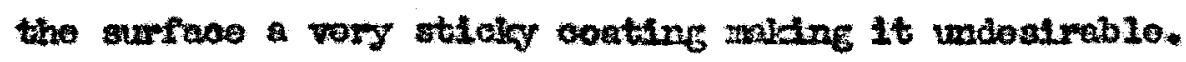

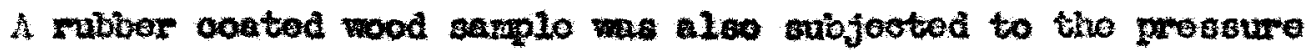
oyoles. Hovevor, artor 6 ogoles it devolopod axtace bllotors indicatIng the rupture of the rood-rubber bond.

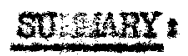

The olese acld and the oopper napthenate prowod unsatiafaotory as lingrogatine agents bince thoy bad a tendonoy to lesoh out upon erbjeotion to the preasure oyolos.

Yovevor. all the other inuegnoting agents testod, partioular-

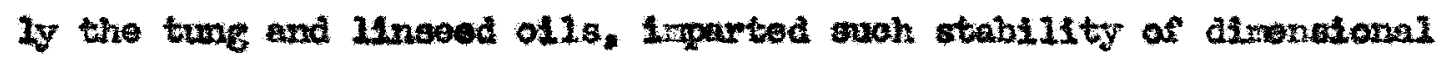
end welght changas to the mahogary and laxdnato that in overy cago thoso two woods proved equal or suporlor to toat wood.

Decause of struatural fallwe, both the hirch wood and the rubbor ooated weod groved meatiafactary for this partloular use.

It is rooomendod that the mogary-gaplo 2 aninato be triod

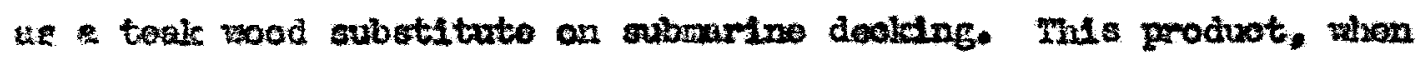
trontod, bal botter alronstonal stabluty and mator ropollonoy then teak, and unlibo plain mahogazy it has a hard wear resistart surioco. 


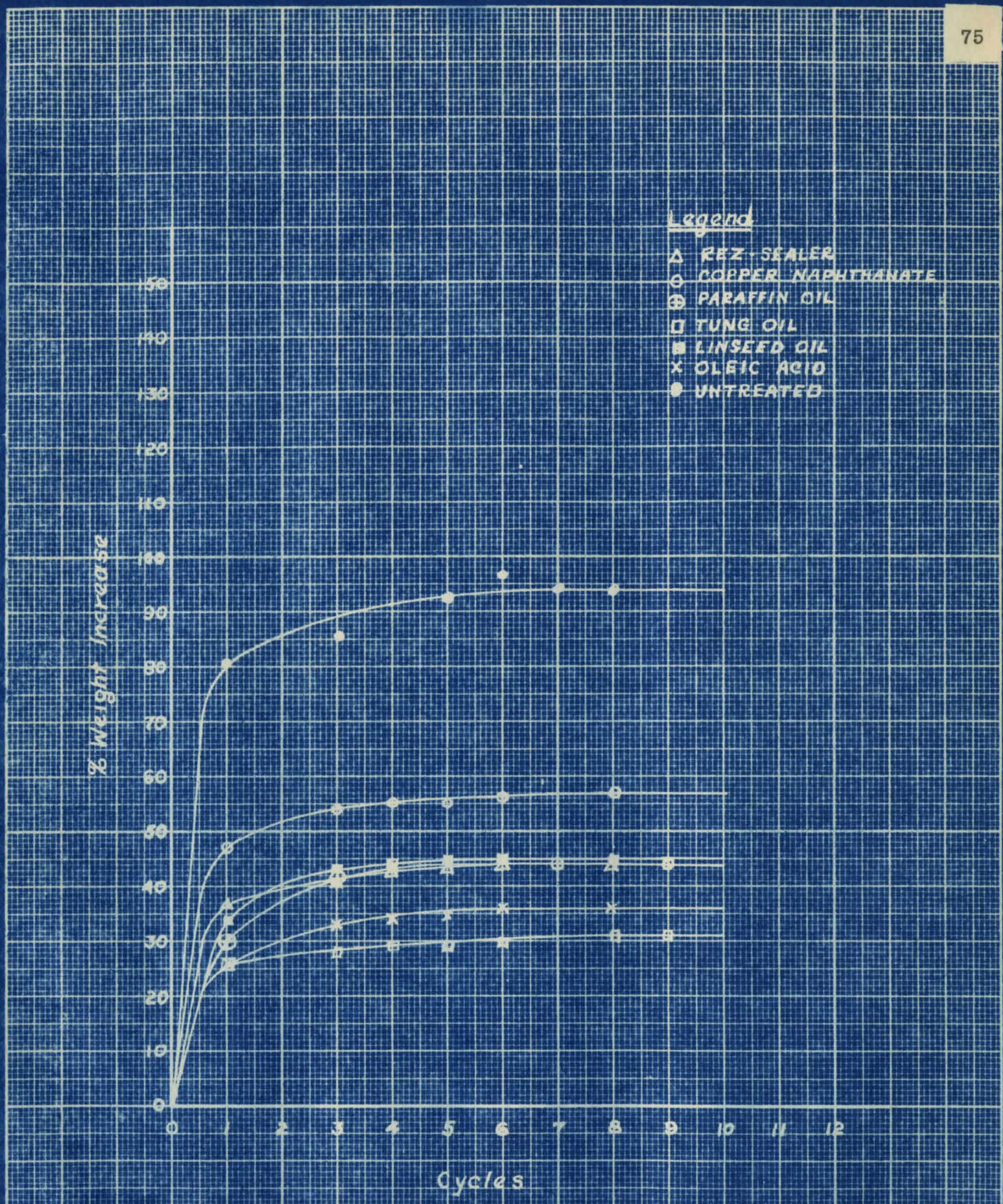

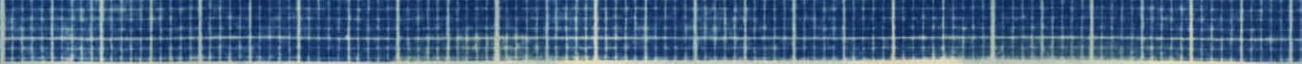

Fig. 17 Weight Increase of Treated Birch During Pressure Cycles in Salt Water. 


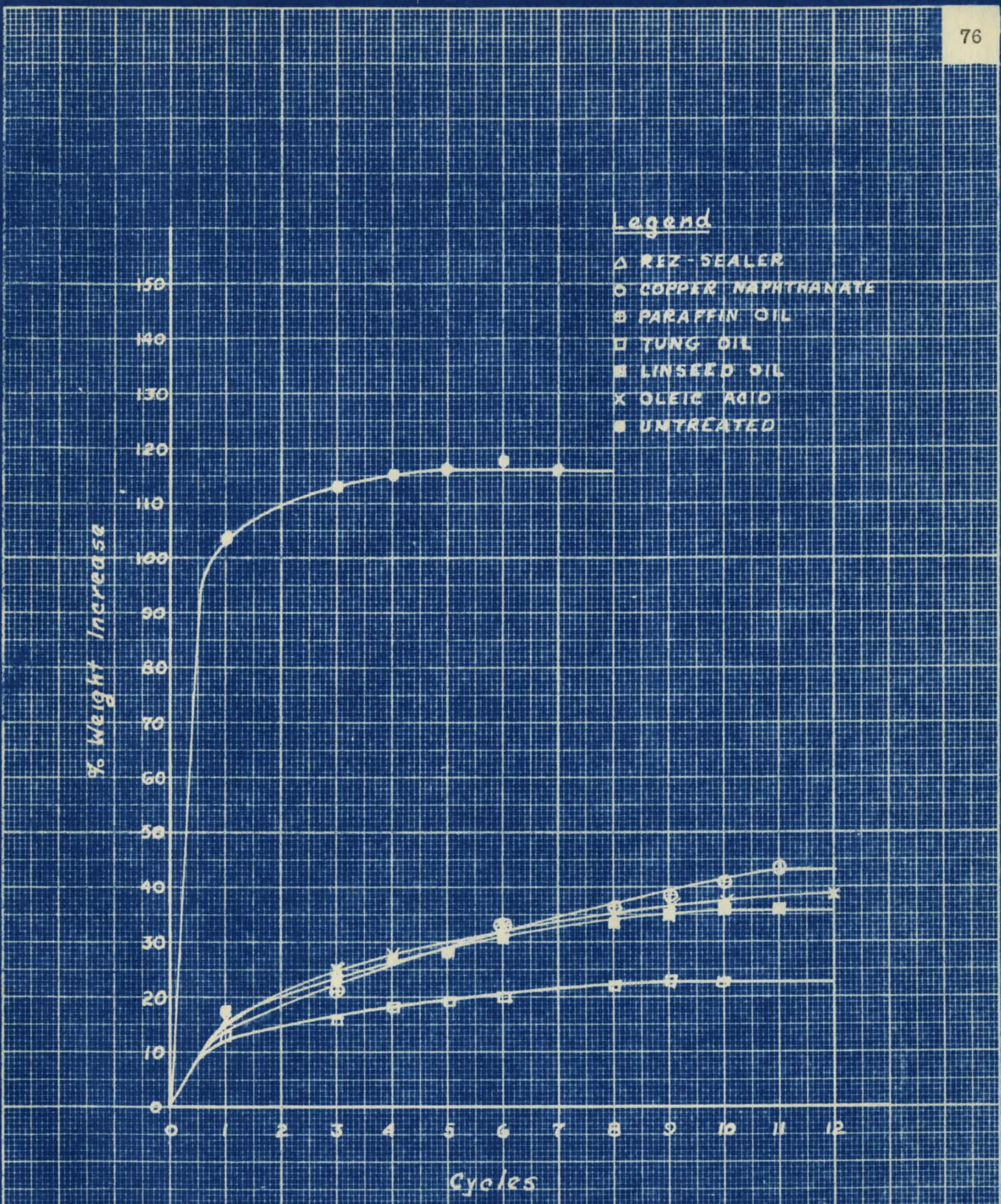

Fig. 18 Weight Increase of Treated Laminate (Maple Faces, Mahogany Core) During Pressure Cycles in Salt Water. 


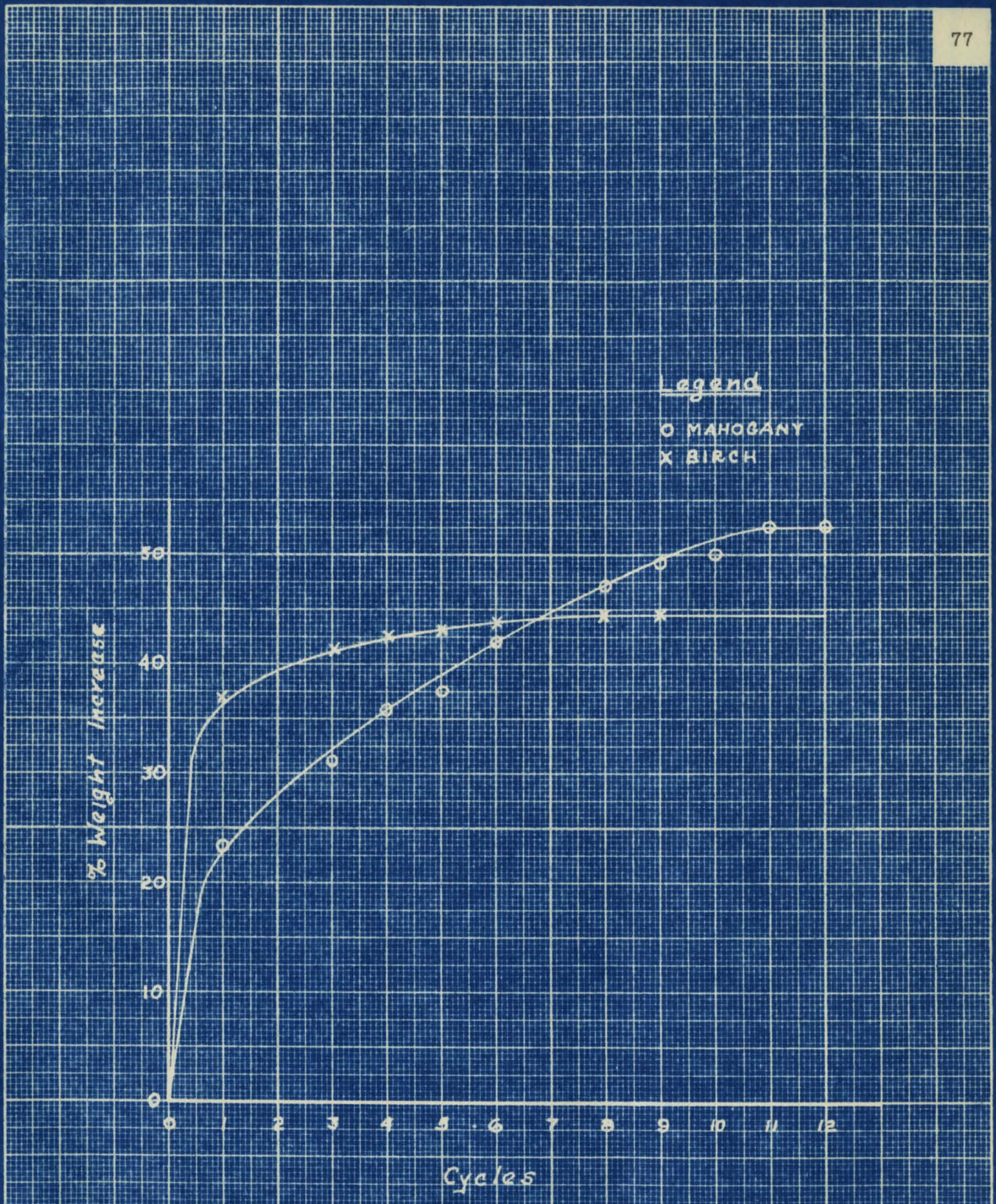

Fig. 19 Effect of Species on Weight Increase of Rez Sealer Impregnated Woods. 


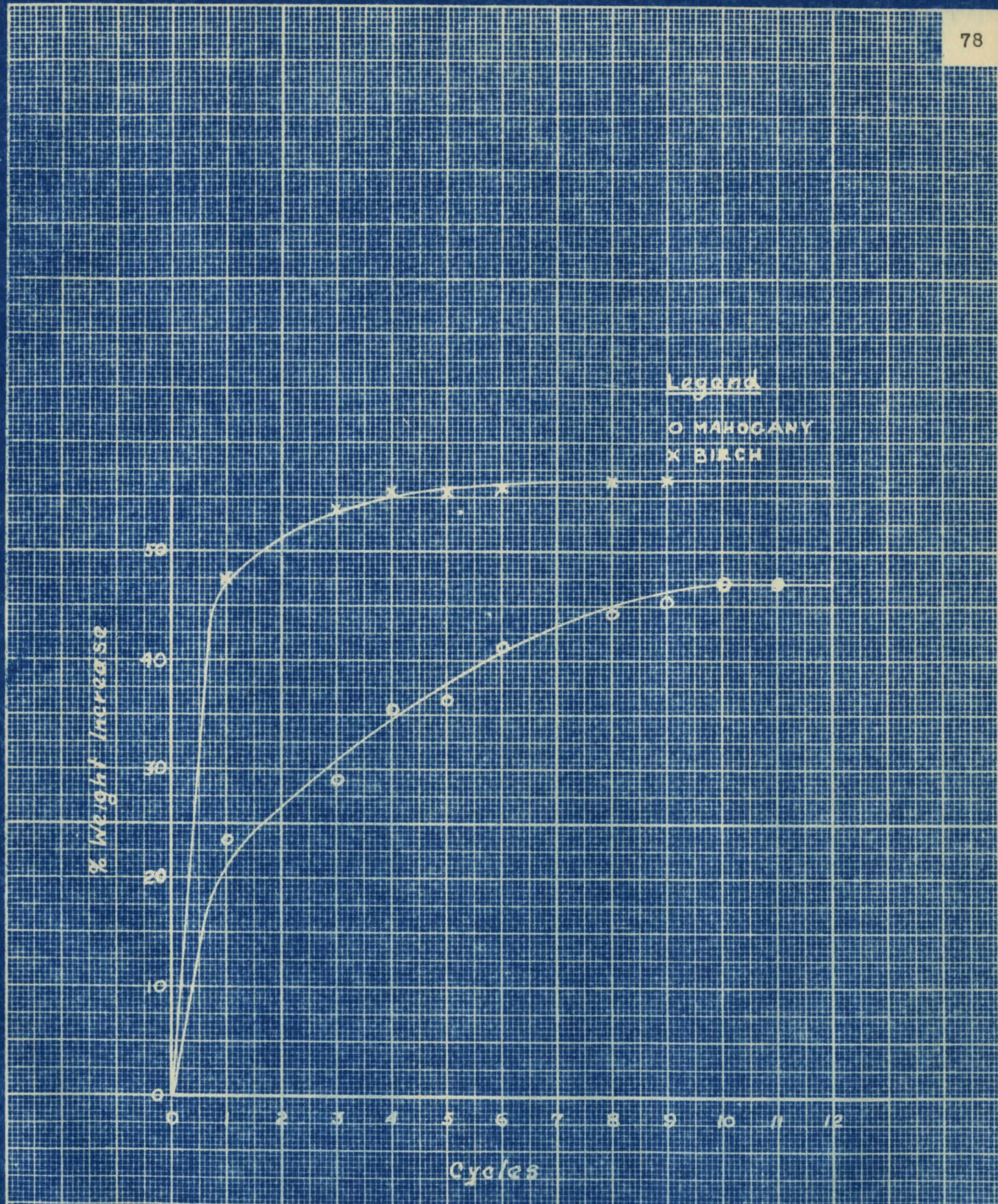

H.

Fig. 20 Effect of Species on Weight Increase of Copper Naphthenate Impregmated Woods. 


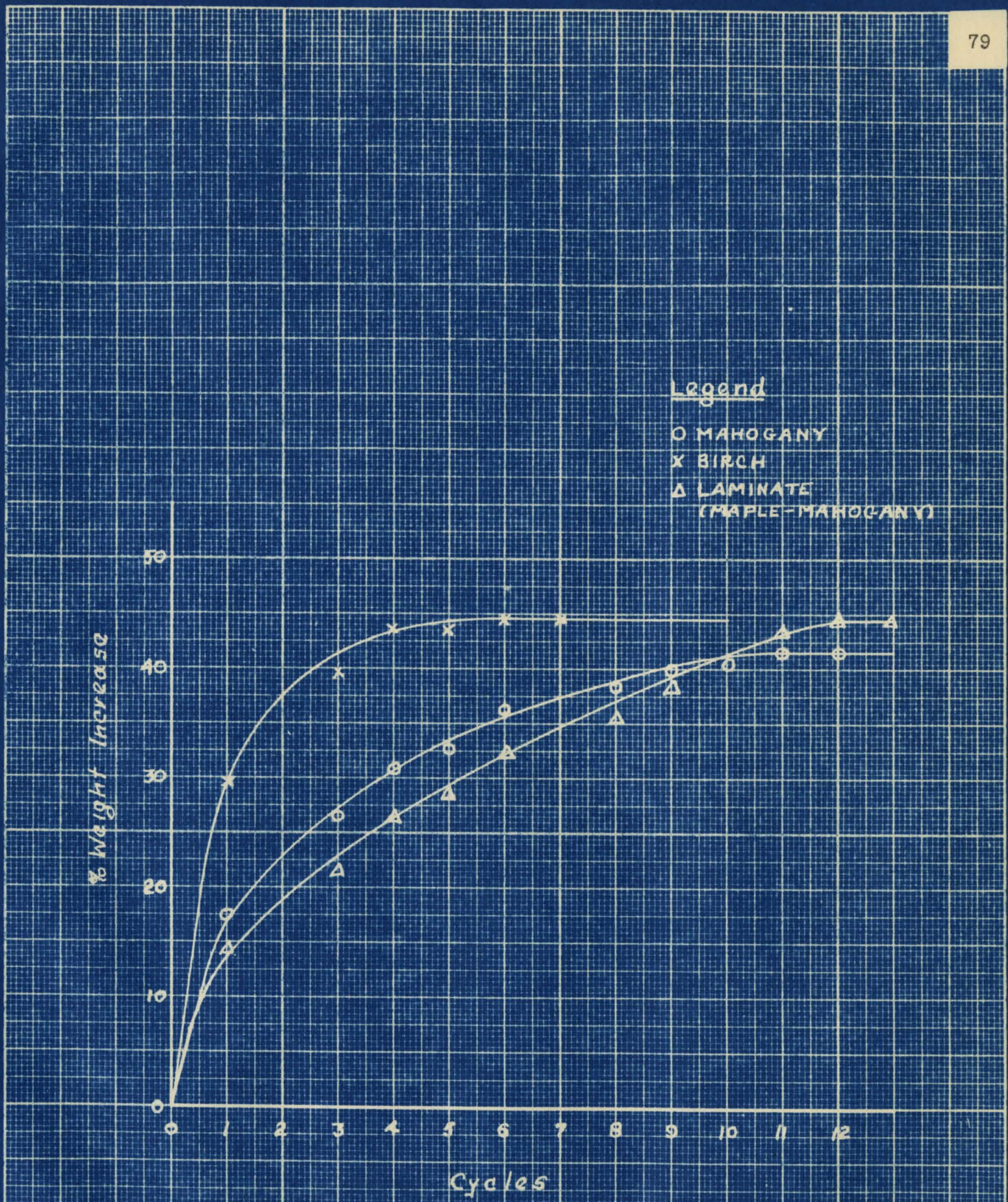

Fig. 21 Effect of Species on Weight Increase of Paraffin Oil Impregnated Woods. 


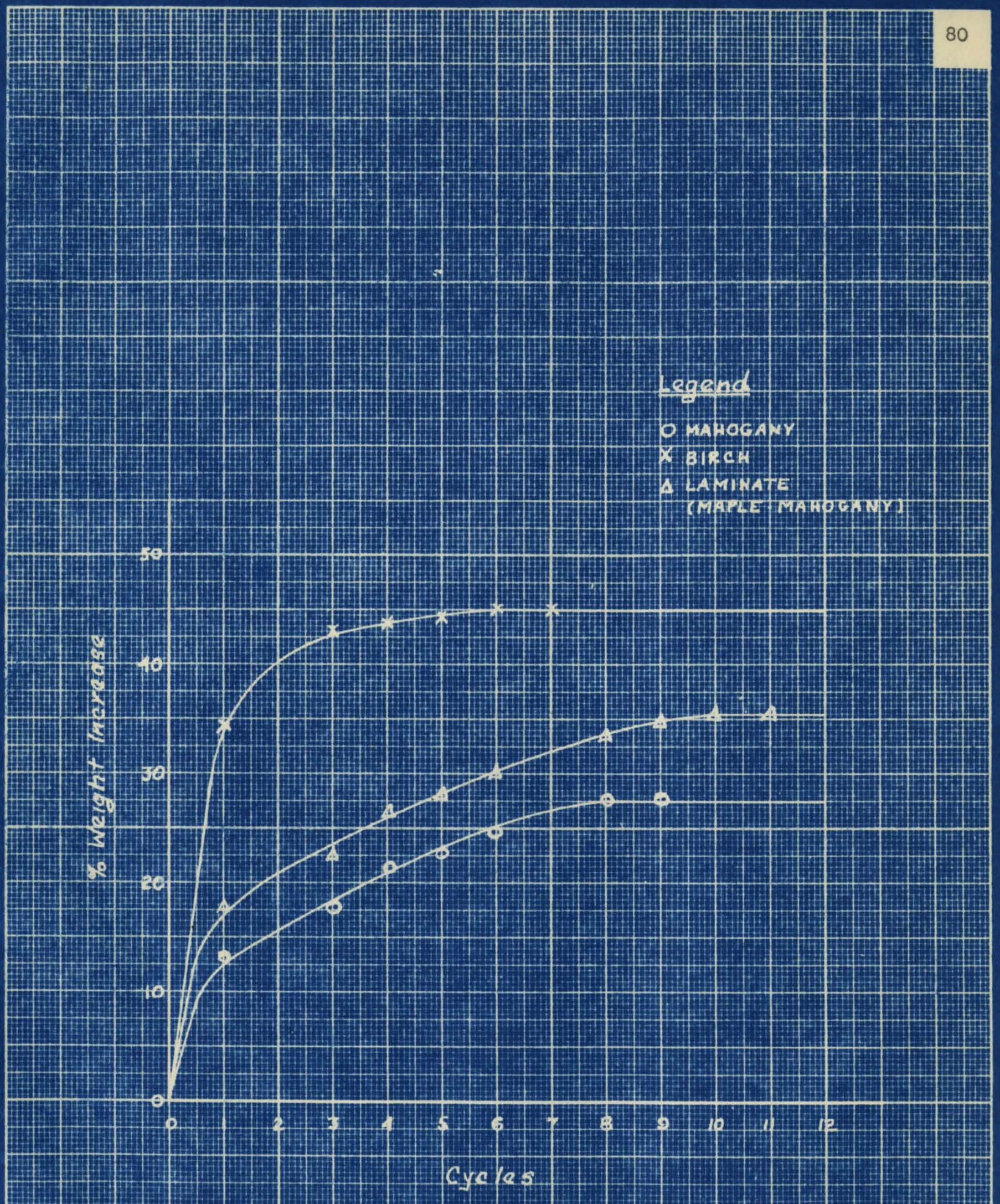

Fig. 22 Effect of Species on Weight Increase of Linseed 0il Impregnated Woods. 


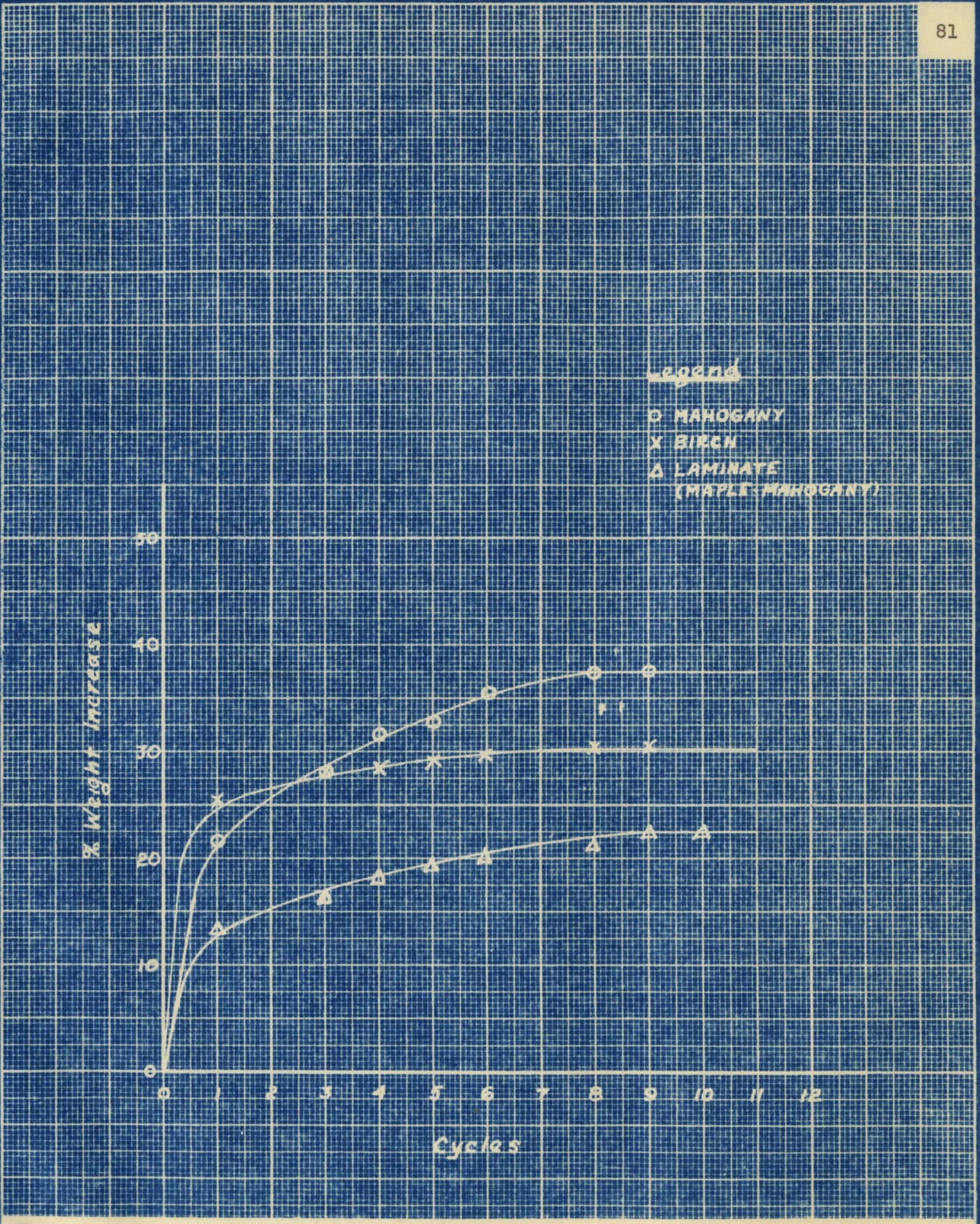

Fig. 23 Effect of Species on Weight Increase of Tung Oil Impregnated Woods. 


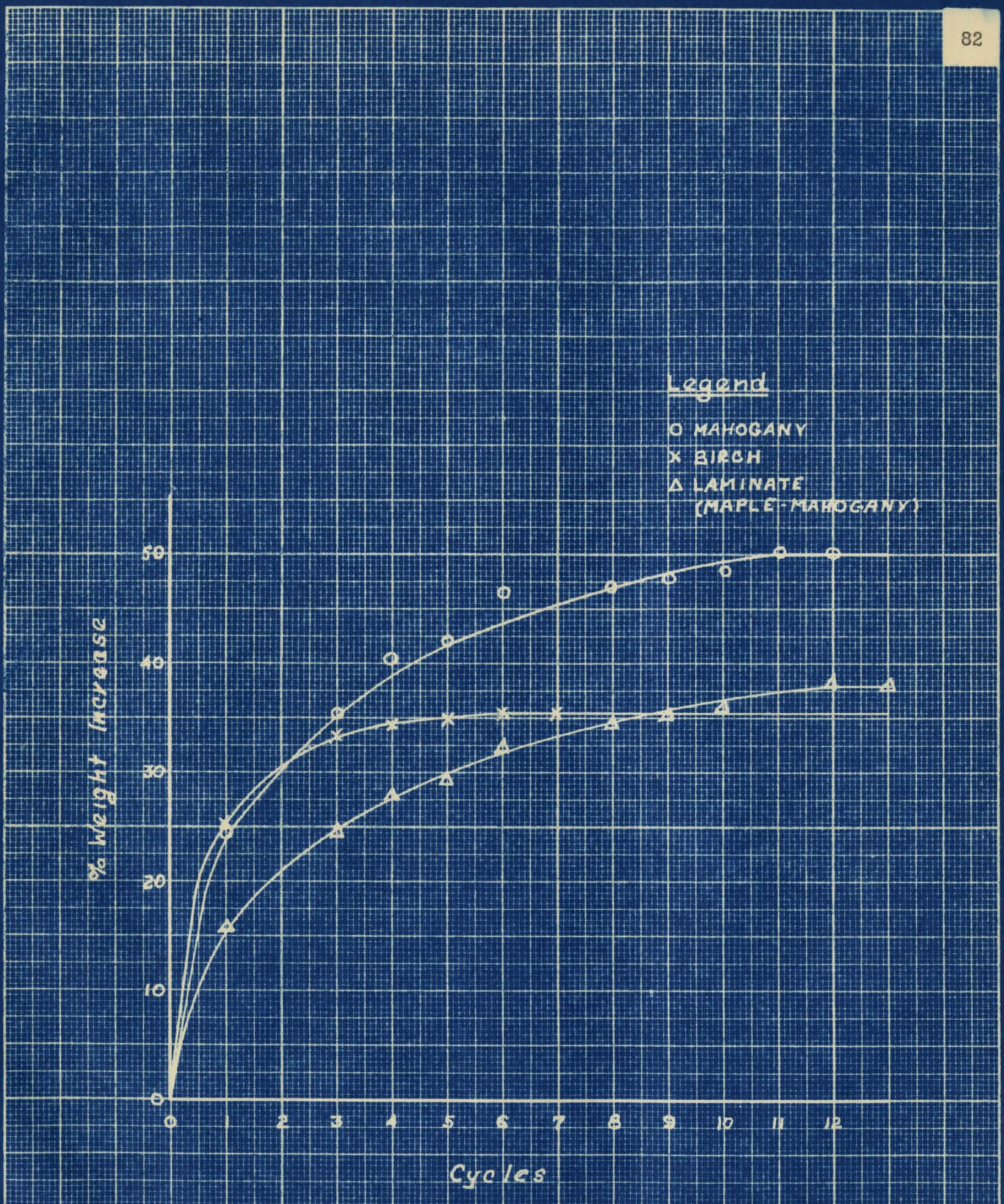




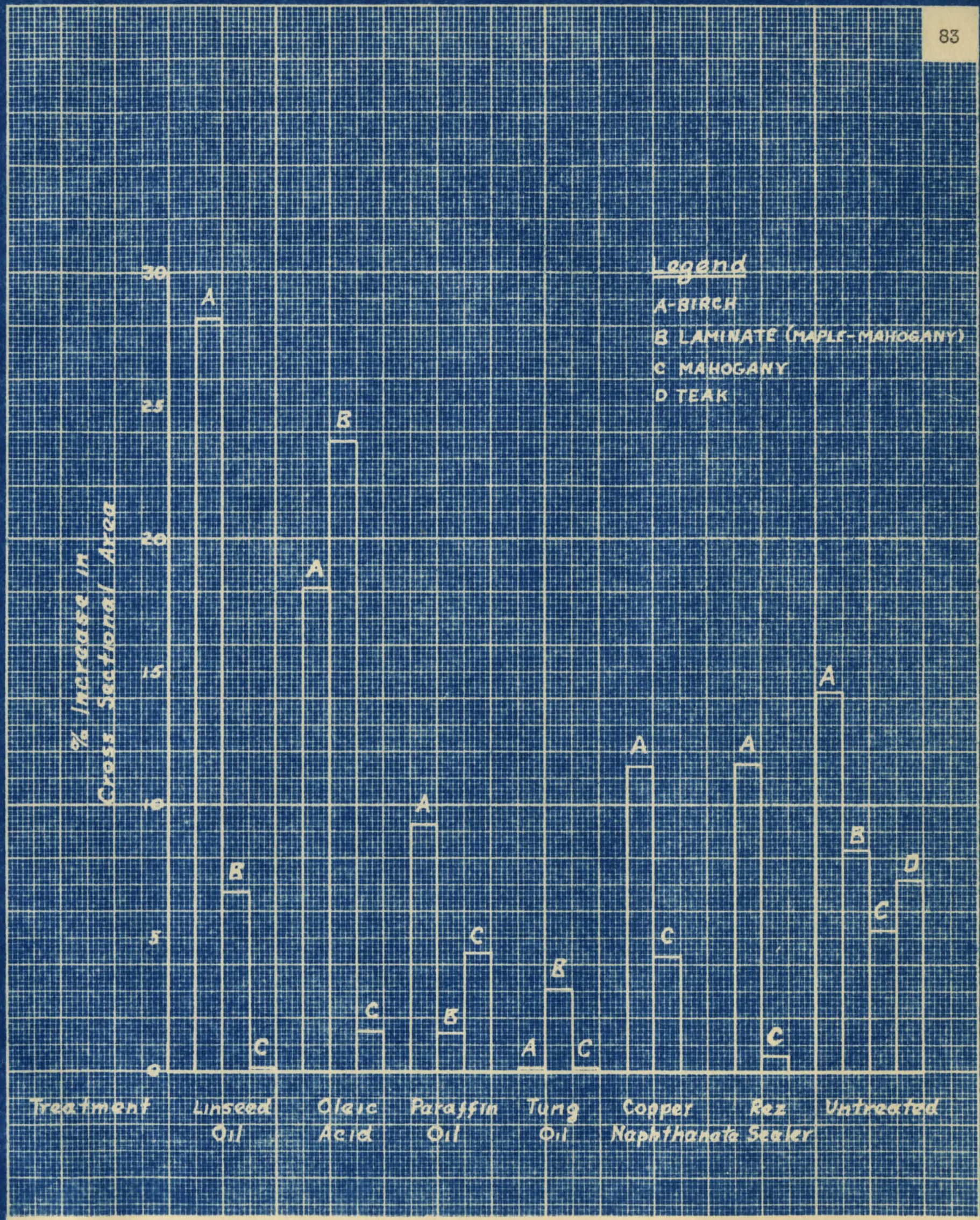

Fig. 25 Final Dimensional Changes of Impregnated Woods After Pressure Cycles in Salt Water. 


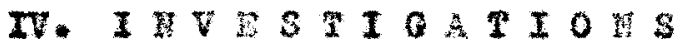

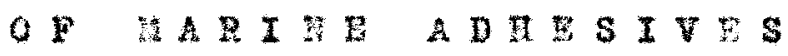

I I I ODUCTI 
The ast atisfatory acheatros used in the manucture of wood lantrates for marine use are aymatho resing of the phenollo aldotyde type. 3inoe these adhestvos are oured at olevatod terporeturos and prossures to Inamo proper Donding. tholr optiman curing oondstions rast be detomined.

The purpose of this work was throe fold A) po dotormino

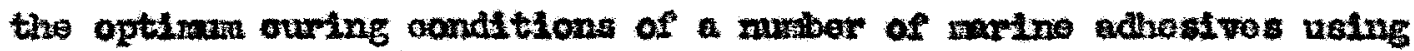

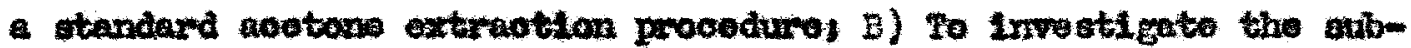
atitution of an X-ray diffraotion proeodure for the aotone extraotion

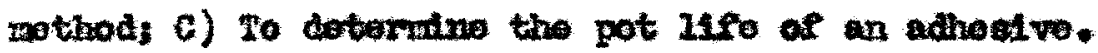

A. Detornination of optimun Curlag Condtions of ixtino Adhoulvos. foetono Bxtraction Prooedure.

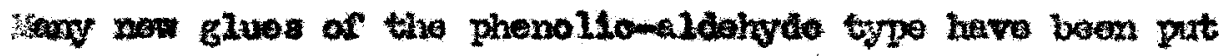
on the parket inde the beginntng of Norld War II. However before bolng used in produotion, the ramifacturer onrries out various bests on tho adhesive to doternine its sultability for the particular use. In copparation with Cando Irothers, Ino*, mators of

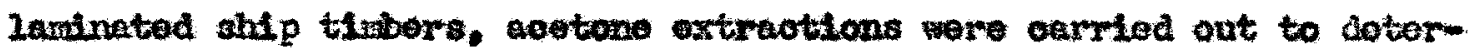
mine the optimm ouring torporatures and timos on muber of resin adbeatwa.

D. Dotoratination of Optimun ouring conditiono - X-ray Diffraotion Prooodure.

Such prooeduros as the aootono extraction for deteruining the suro of reatn adhobivos are long. tedious, and greatly dopondont upon human acouray. The prooodures, moreower, onmot be applled to glnod 


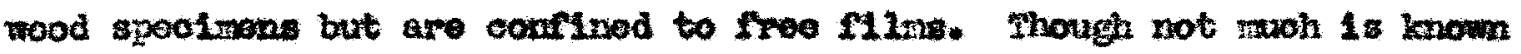
of the nature of the glue baed, thore is oridenoo indicating that free glue MIIns are of a difforont natrace from that of gluo oured in oontect with wood.

It was tharefore the parpose of this X-ray dffrection study to ollintrato the acetono oxtration prosodumo and at the sarb timo add to the ovidenoo on tho nature of the glwo bond. Furtherrore thic peo-

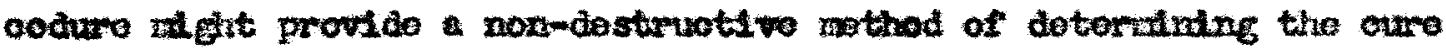
of gluod wood spootmons.

C. Detornination of the Pot Lifo of Rosin Adhosivos - Verosity of atsod Casoophon $15-67$ shestros.

Whe pot lifo of restn adhostvo dooreases with trorose in

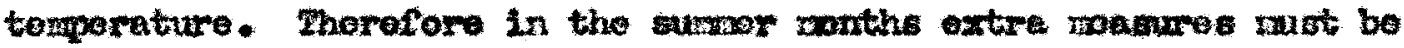
taken to insure propor pot Ilfe.

Casoophen $1 T-67$ (a noutral phonolie kIdohyde type resin)

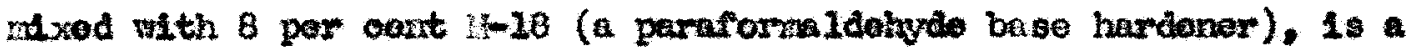

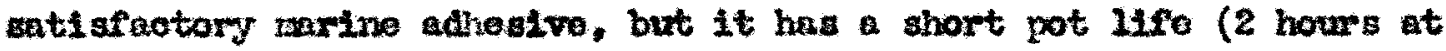
80\% . It has boen roported (8) that the nae of Pifso hardonor (re-

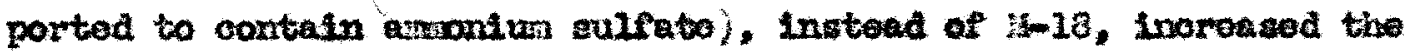
pot Ilfe of the resin to 70 howrs at $80^{\circ}$.

This gootion was undertaluen to longthon tho pot 11 fe of

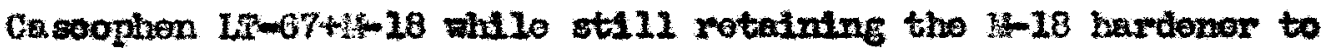
Inouro ouring and wonthoring oharateristies. 


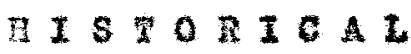


ran attorats have been rade to find a rapid, nocurate teat for doterminting the dogreo of oure of arino achostres. Although aotux 1 sarvico is the only war teat. some information can be galned by a nursber of prooodures.

For sone tira the proteotive conting lindustry hes used oolvent oxtraotion prooedure in folloning tho polymaritation of realin

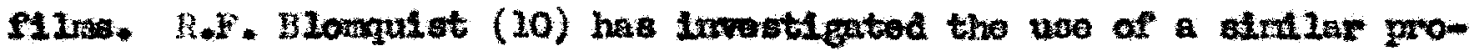
oodure in doternining the oure of robin adhosivos by bootono extraotion. Tie has shown derlnito corrolutione botwoen por cont oxtraotiblos and rolative degree of ouro when the glue is cured on a chemionlly lnort aurstuce.

Sany X-ray atudies hnve been rade of sycthetio reatns and oompounds of the types whioh are sudooptible to polvnorization. The courso of acotylation of callulose bas boon followed wh th $x$ may photographs by noss and Tregues (11).

E111s (12) has prosented $X$-ray defraction pattoms of a phanol-forraldelvide rosin at 3 difforont agos of oure. These pattorns Indieated that as condenents on proveded the rosin otruoturo booano mo

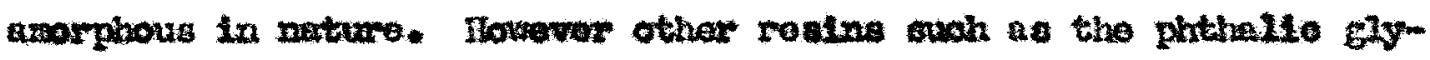

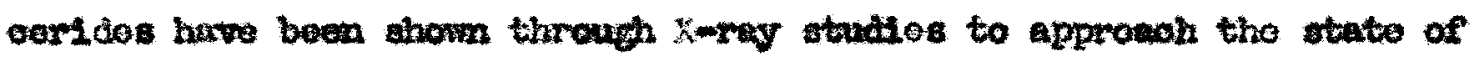
oryatallinity as condonantion provoods.

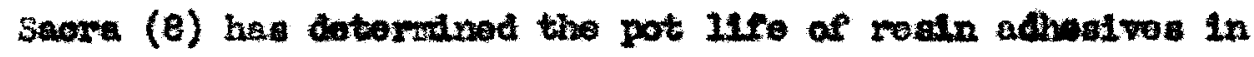
torms of visoosity obangen using a 4 Ford visoostty oup. ito found that if the the for a flow of $50 \mathrm{ml}$. exrooded 400 soconds the Glue wae too visoous for satiafaotory gproding. 


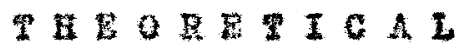


The ouring of a reatn adhoalve of tho phonolle aldolyde type

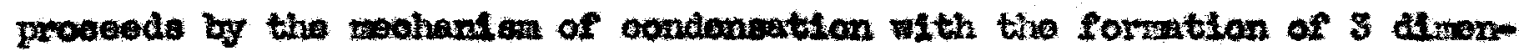

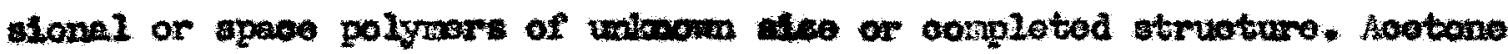
hea the oharaotoriatio of asoloing low and watwo noleoular wolght polymors of this typo. Theraforo as the oure proveods and lose 10 molooular welget polynars are meant tho peroent extractiblok should doorease. This has been foumd to be partiy two, 1,0., the paroent axtractibles

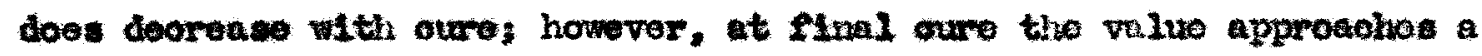

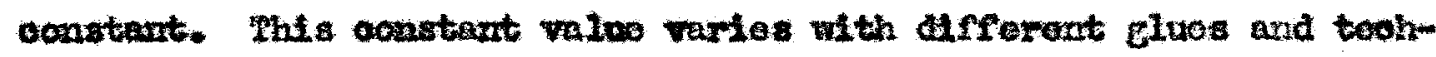
niquas of extraoting.

Ary two substanoos wioh are not lidentionl in otruotaro w11 gro afforont $X-$ ray pattom. It 18 upon this frot that the attorpt to

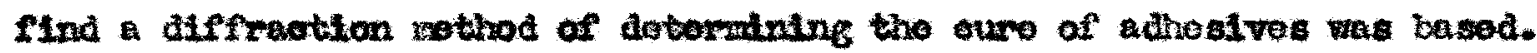
As the ouring of the athesiwe proopeds, tho X-ay pattem oamospondingly

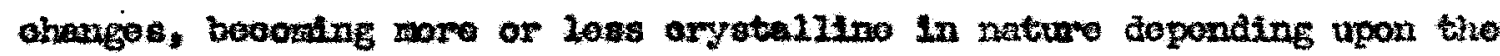

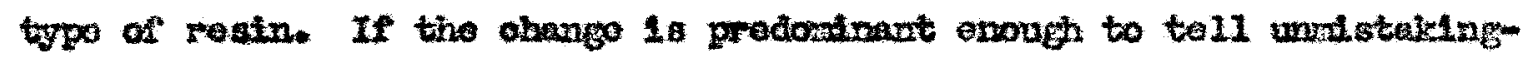
Iy how far the aure has mooeded it mould bo posaiblo to shro a very

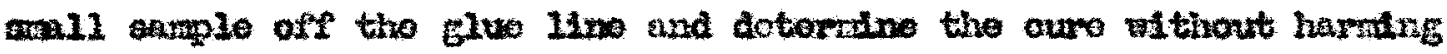
the finchod glued vood products. Fhus this mothod would eliminato a

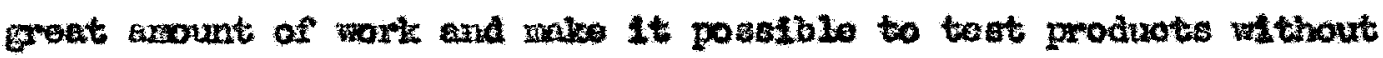
dogtarution.

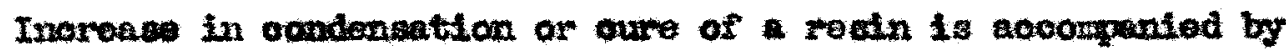
Inoroas in visoosity. Fven troon temperature ouring talses plape.

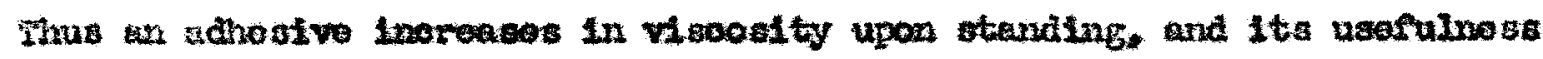
way bo dopondent on lto pot ufe. 


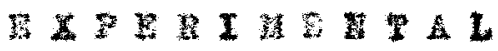




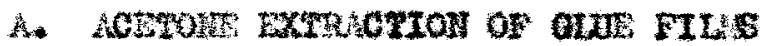

The use of acotone extraotien of penterod glve flun is ande to determe the optinus ourlng cenditions of the ndhostro.

\section{SPAthins:}

The waln aptaratue ned we a bettory of Soxhlet extraction

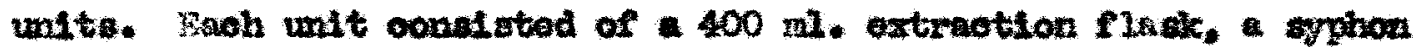

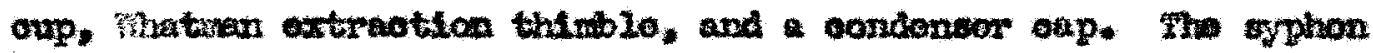
oup oontaining the extraotion thinblo was eraponded by flno wiro from

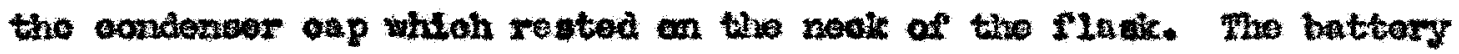

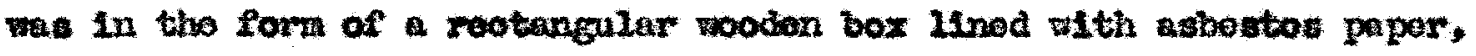
and Itted with a removablo 14 in which holes were ont to reoolve the axtration flasks. The paras wore placod in oyllndrioal metal fot loom

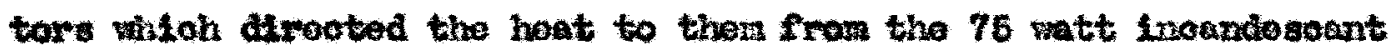
larp hoaters located on the botton of tho battery. Cooling water for the oondeneers was suppllod through on 1 ron ptpe ranifold, and the cooling syeten of the battory sas aornocted in parallol.

Laboratory elootrlo owans wore ubet to owre tho glwo flizis on glase plates. A standard wortar and postlo wero used to hand pouder tho filras to pass turough a 48 mon Mylor Standard Soroon. 
mocturte:

Tho proodure oonsteted of prepartac the adhoatve. ouring it on glass platos in ovomo at proscribod tenporaturos and tiwe, grindIng the slakes, and extraoting with acotono.

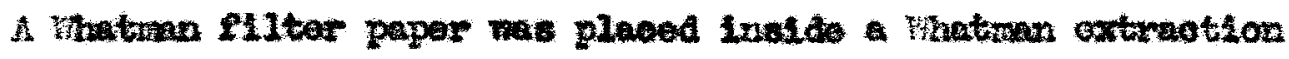

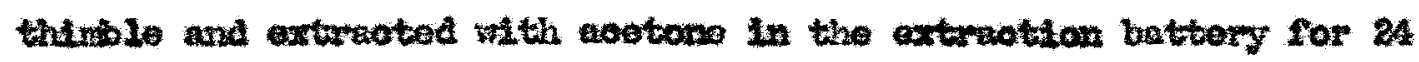
howes. The thasbio was then aried at $120^{\circ} \mathrm{c}$. In wa oleotrie oven for

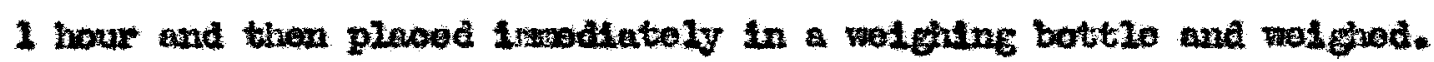
The adtodive was med avoording to the proportions and

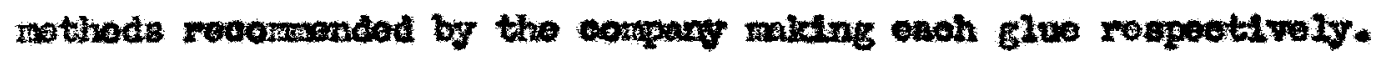
It was spoad thinly on glass plates and owrod nooording to pro-

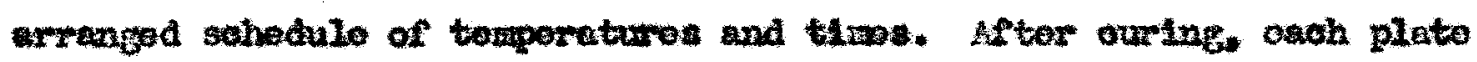

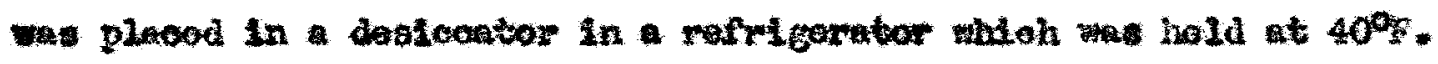
These gltwe flakes wore thon hand powarod by wotar and posto to paso 48 aven Iylor standare soroon and Imodiatoly replnood in the

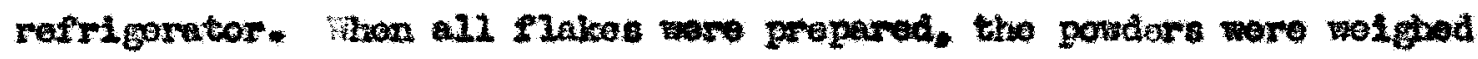
Into the soxinlot extraotlon thitolas and ano oxtrotod for 24 houra.

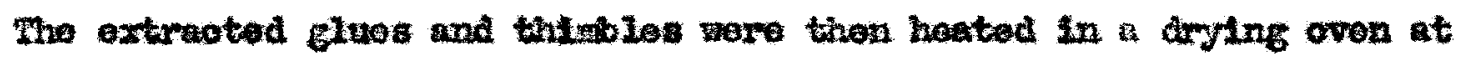

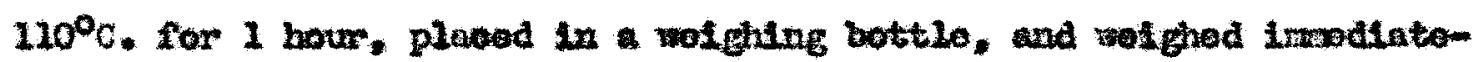
17. The lose in weight was rooorded and ealeulated as poraent nootono extraotiblo on an Intulal volgt batia. This prooedwe mas standard-

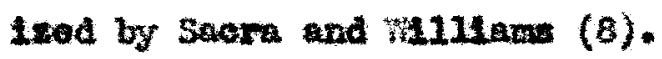


ADIXITHS RESTED:

Durea 12688, a wator soluble 2kquid phonollo reasn (100 parta) plua hurez 12080 poudaved hardaner (20 parts) mandachured by Duroz Mastios and Chentorle, Ino.

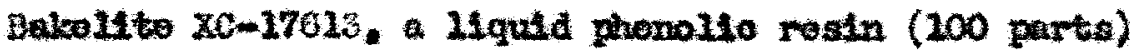

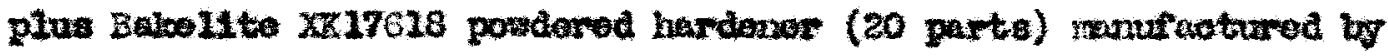
Saloellte Comporation.

Dikelite xe-17540, powdarad phowolke nosth (200 parta) plus eloohol (30 parto) water (30 parts) and Baleolite XI-17545 a

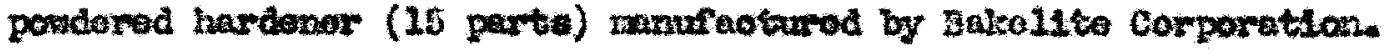
Fivopien 6000, 14quid phonollo rodin (100 parts). ontalning approxtratoly 60 per oent oollas in an aloohol vater aolvont. plue plyophon 6001 pondorod hardener, (18 parts) a

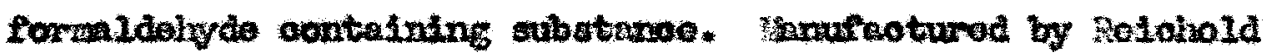
Chentosis, Ine.

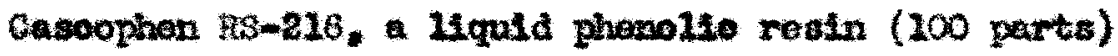
plus Gaveophen Fis 60 powdorod hardonor (15 parts) manufactured by the Casein Company of Aremion.

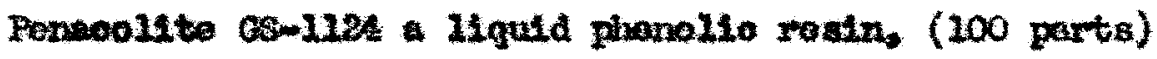
plu: Ponuolito cs-1124 14quid handeror (25 parta) ranufacturod by

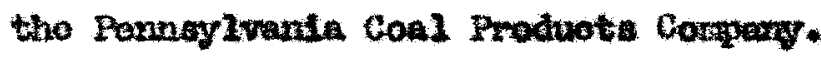

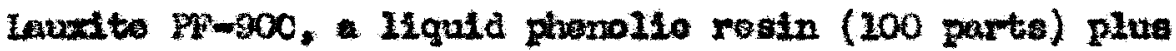
Lawito Hi-30C, a powdorod hardoner (17 parts) mamperturod by I. Inok, Ino* 


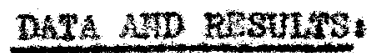

Tho Dures gue flakes wore dart waron in color, hard. britt10, and hed a burnt wood odor. Tho soetono aftar extraotion hat a rust oolor tooronsing in intonsity vith lnowoase in oure.

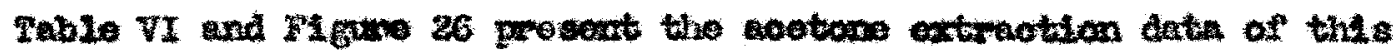

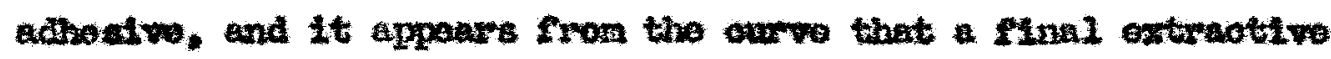

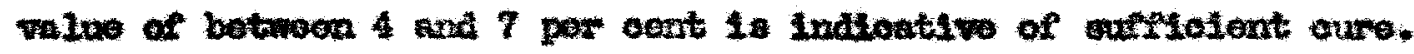

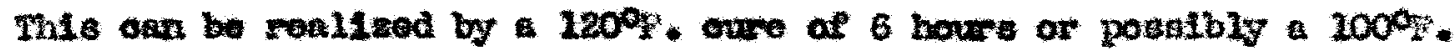
oure of 6 to 24 hours.

The Bakellte $x 0-17613$ gIus Plates were brow in oolor. brittlo. but not quite so hard or tough as the Dhare gluo. Exoopt

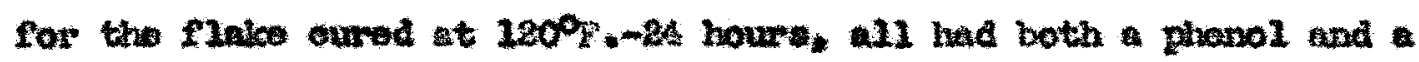

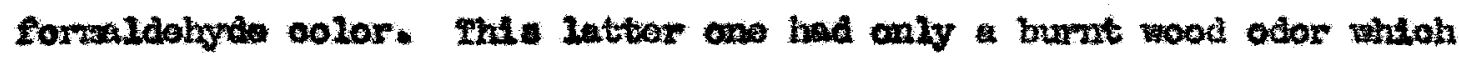

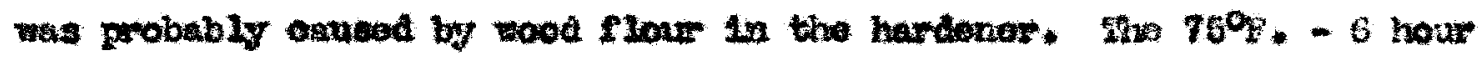

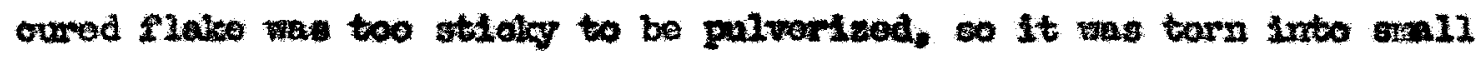
piooes and oxtreoted. Eoth tho o bour end 24 hour 51 lacos ourod at 750 .

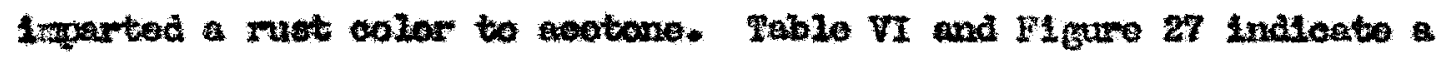
rolativoly high flunl axtruotivo ralue of 20 to 28 per cent. This

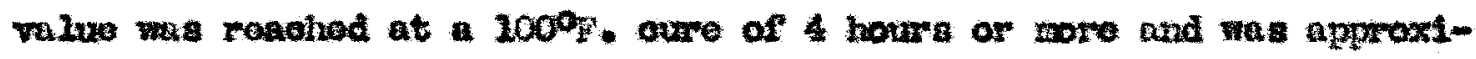

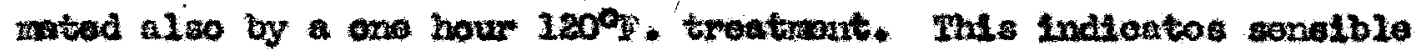

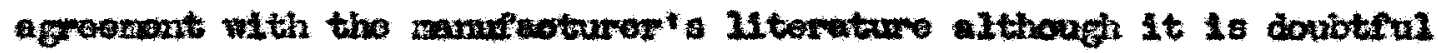

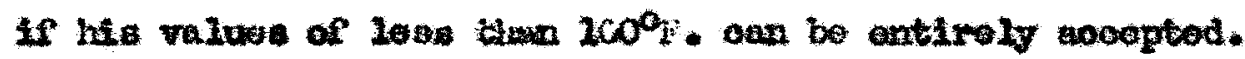
The Bakell to XC-17540 glvo flake wore maroon In color and equal In hardwess to Ealkolt to XC-17613. The 8 how and 24 how flakes cured at $160 \%$, and the 15 minuto flake ourod at $200 \%$. had formaldohyde odors. Both the 8 hour at $160^{\mathrm{m}}$. and tho 16 minute at $200^{\circ} \mathrm{F}$. 
Llatos Impartad oloudy oulor to the wootom upon entradtion. The Iatter to a greator extront. The notano extraotblo vilues for this

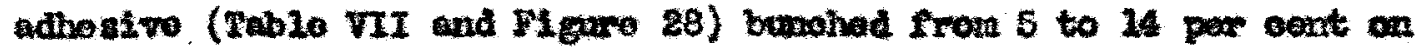

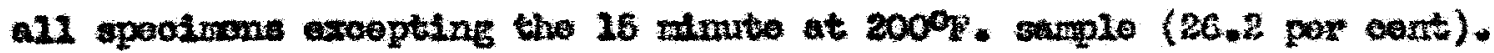
Athough two and point 1 s not couplotely estabu ahod it appora that

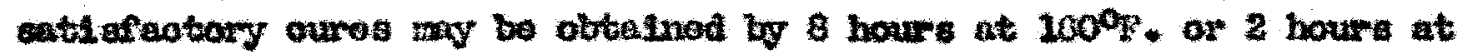

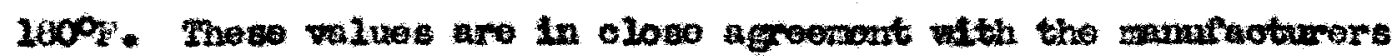
reoontandations.

the Pyophon 6000 glwe plates wore dark maroan and. exaept

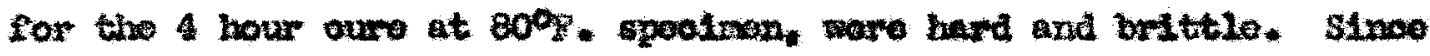

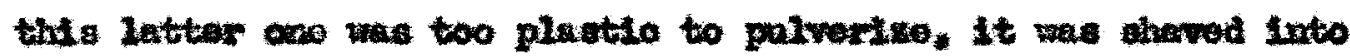

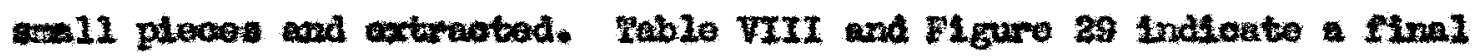

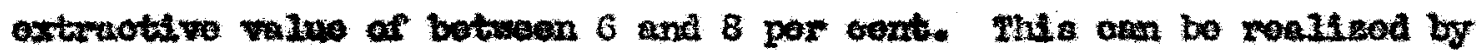

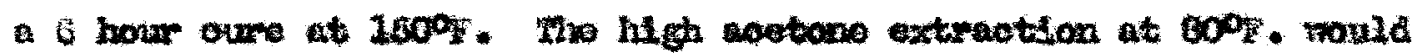
not warrant ourlng tho adroatvo at the temperaturo.

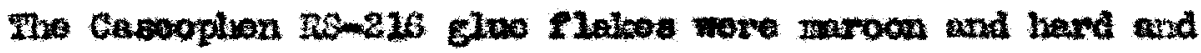

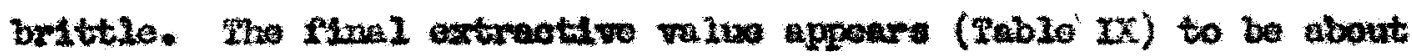
24 por cont. Thus 14 appears that the oure oan bo attalned at 150\%. In 4 bours of $1200 \mathrm{~F}$. In 6 to 24 houra.

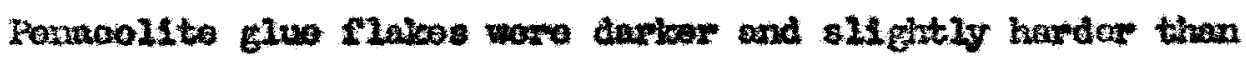

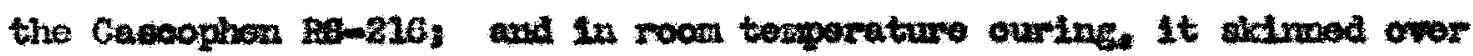
Wth the rormation of a relatively unicled surfaco. This adhosivo appoars to roweh a final asotane oxtraction ralue of botwoon 12 and 16

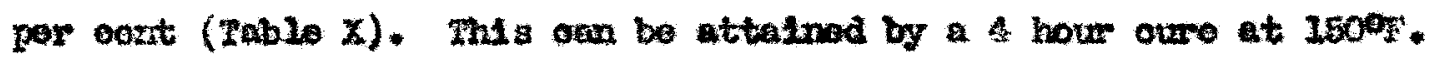
or a 24 how ouro at 120\%. 
The relatively high noetwo axtraotion mine of thase last two glues tro not neeessarlly Indicative of poor gluo bonding on wood. for they may be wanged by the nature of the adrotive. Howorer, as has boen mentionod, at full ouro tho value should bo oongtart.

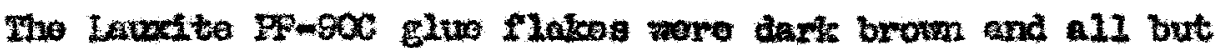
the 4 and 6 hour oures at $80^{\circ}$. wore hand and brittle enough to pulvorizo. Those last two moro luved into all plooos and axtractod.

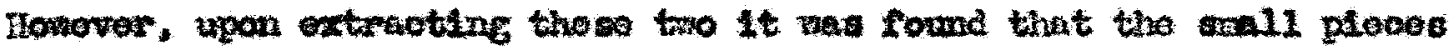
hod fuad togativer to form a oase hurdoned mass thoreby hindering oom ploter oxtratalon. The Iow ralwa show in sable XI for the 4 and 6 how own at $30^{\circ}$. bear out the comolubion of inoomploto extreotion. The plot of por cont extractiblo ve curtag terapereturo of wigxo 30 , though

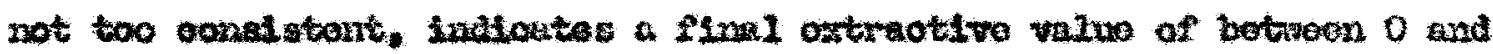

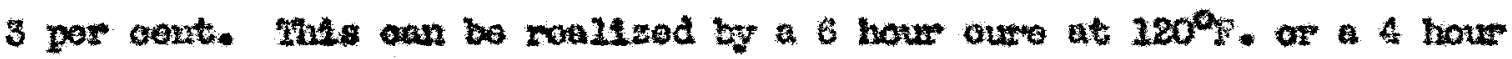

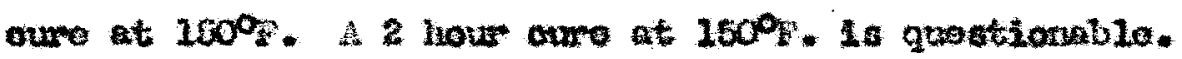




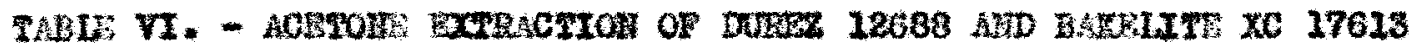
AXIEgrves

Por Cent Sotractiblo

\begin{tabular}{|c|c|c|c|c|c|c|}
\hline \multirow{2}{*}{$\begin{array}{l}\text { Gurlng } \\
\text { geaze }\end{array}$} & \multicolumn{2}{|c|}{ Dures 12680} & \multicolumn{4}{|c|}{ Bake11 be XC 17613} \\
\hline & 6 hours & 84 poure & 2 novx & 4 hours & 0 bowes & 24 houre \\
\hline $75^{\circ}$ & 17.8 & 5,15 & & & 62.0 & .21 .0 \\
\hline $100^{\circ} \mathrm{W}$ & 7.76 & 6.66 & & 22.5 & 23.5 & \\
\hline $120^{\circ}$ & 6.62 & 5.81 & 20.3 & & 20.0 & 19.0 \\
\hline
\end{tabular}

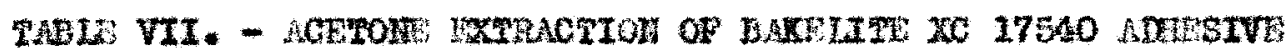

Por Cent Jxtraotiblo

Curlug

rexpe.

1/4 hour 2 houre 6 hours 24 hours

$2000 \mathrm{~g}$

20.2

18.4

11.5

$180^{\circ}$

13.0

10.2

5.62

2000 .

12.7

8. 22 


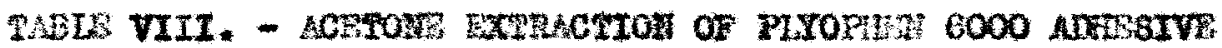

\section{Per Cent Ixtratible}

Crumg

\begin{tabular}{|c|c|c|c|c|}
\hline Texte & 2 houats & 4 haves & 6 hours & 24 hours \\
\hline $00^{\circ}$ & & $24-B$ & 16.0 & 11.8 \\
\hline $1200 \%$ & 10.2 & 9.5 & 7.5 & 7.8 \\
\hline $150^{\circ}$ & $\begin{array}{l}3.6 \\
7.6\end{array}$ & $\begin{array}{r}10.0 \\
2.6\end{array}$ & $\begin{array}{l}8.2 \\
4.2\end{array}$ & \\
\hline
\end{tabular}

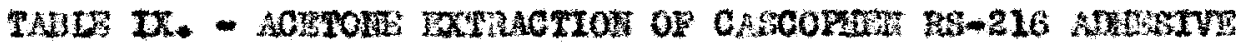

Pex cout Sartantible

Curling

rome.

3 hours 0 hours 24 hours

$900^{\circ}$

$\begin{array}{lll}30.8 & 29.6 & 20.6\end{array}$

$120^{\circ} \mathrm{F}$

$20.4 \quad 28.0$

23.6

$150^{\circ}$

$24.7 \quad 24.5$ 


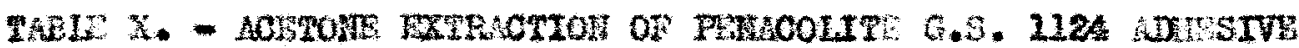

Por Cont Extractlble

\begin{tabular}{|c|c|c|c|}
\hline $\begin{array}{l}\text { Curlng } \\
\text { Tase. }\end{array}$ & 4 hours & 6 houre & 24 hours \\
\hline $90^{\infty}$ & 25.8 & 24.3 & 12.9 \\
\hline $120^{\circ} \mathrm{F}$ & 27.0 & 20.6 & 16.1 \\
\hline $150^{\circ}$ & 23.9 & 17.1 & \\
\hline
\end{tabular}

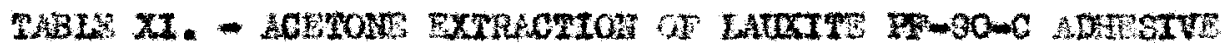
Yor Cont 13xtraotiblo

\begin{tabular}{|c|c|c|c|c|}
\hline $\begin{array}{l}\text { Curine } \\
\text { reume }\end{array}$ & 2 hours & 4 nours: & 6 houre & 28 inoure \\
\hline $200 \mathrm{~T}$. & & $29.8^{*}$ & $10.0^{*}$ & 25.0 \\
\hline $100^{\circ} \mathrm{F}$ & 0.07 & 11.60 & 7.69 & 3.16 \\
\hline $120^{\circ} \mathrm{s}$ & 5.97 & 4.40 & 3.98 & -0.21 \\
\hline $150^{\circ}$ & 3.70 & 1.69 & -1.60 & \\
\hline
\end{tabular}

* Comsidorod umoliablo beoauas of phystoal gtruaturo 


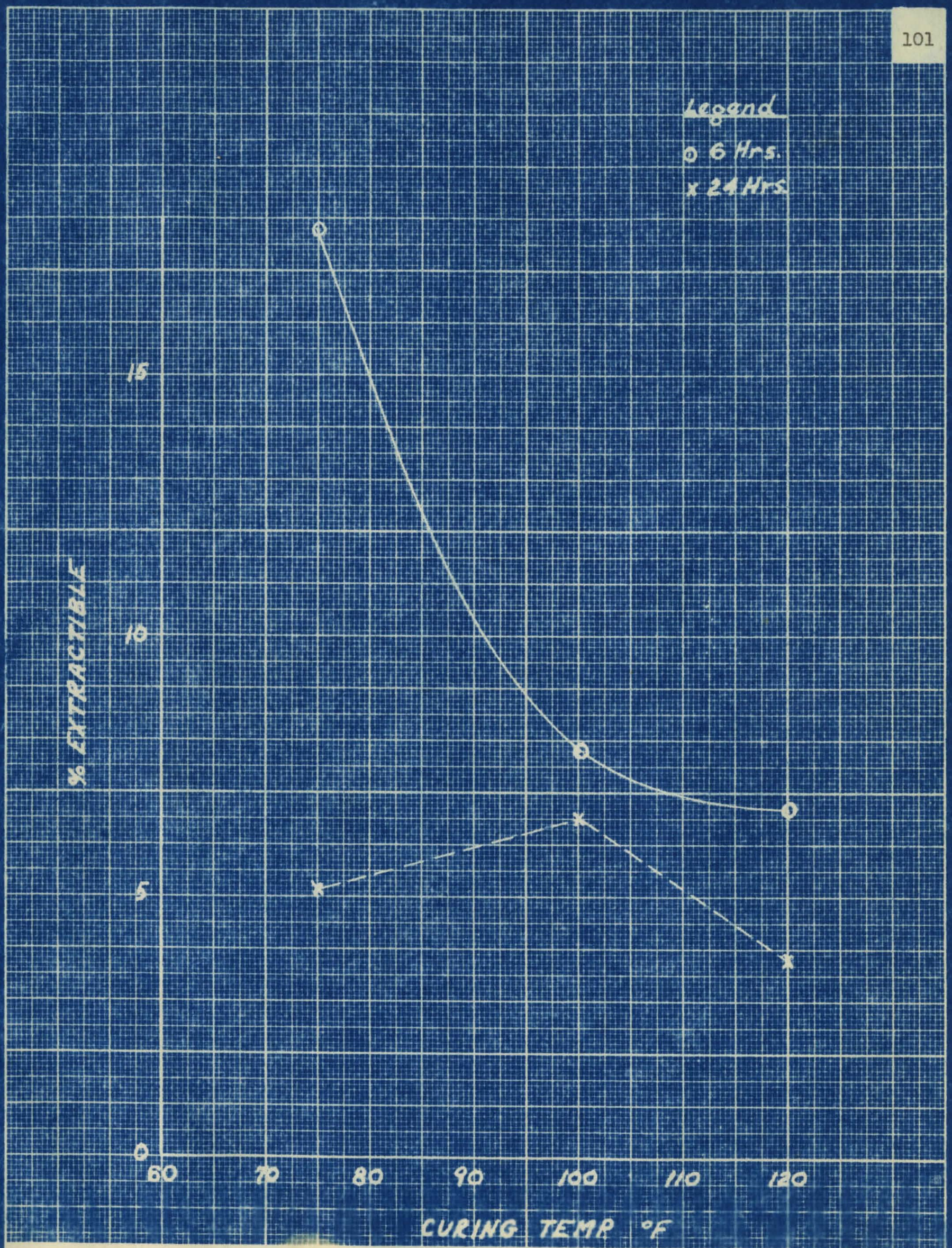

Fig. 26 Acetone Extraction of Durez Adhesive (\#12688 Resin, \#12689 Hardener). 


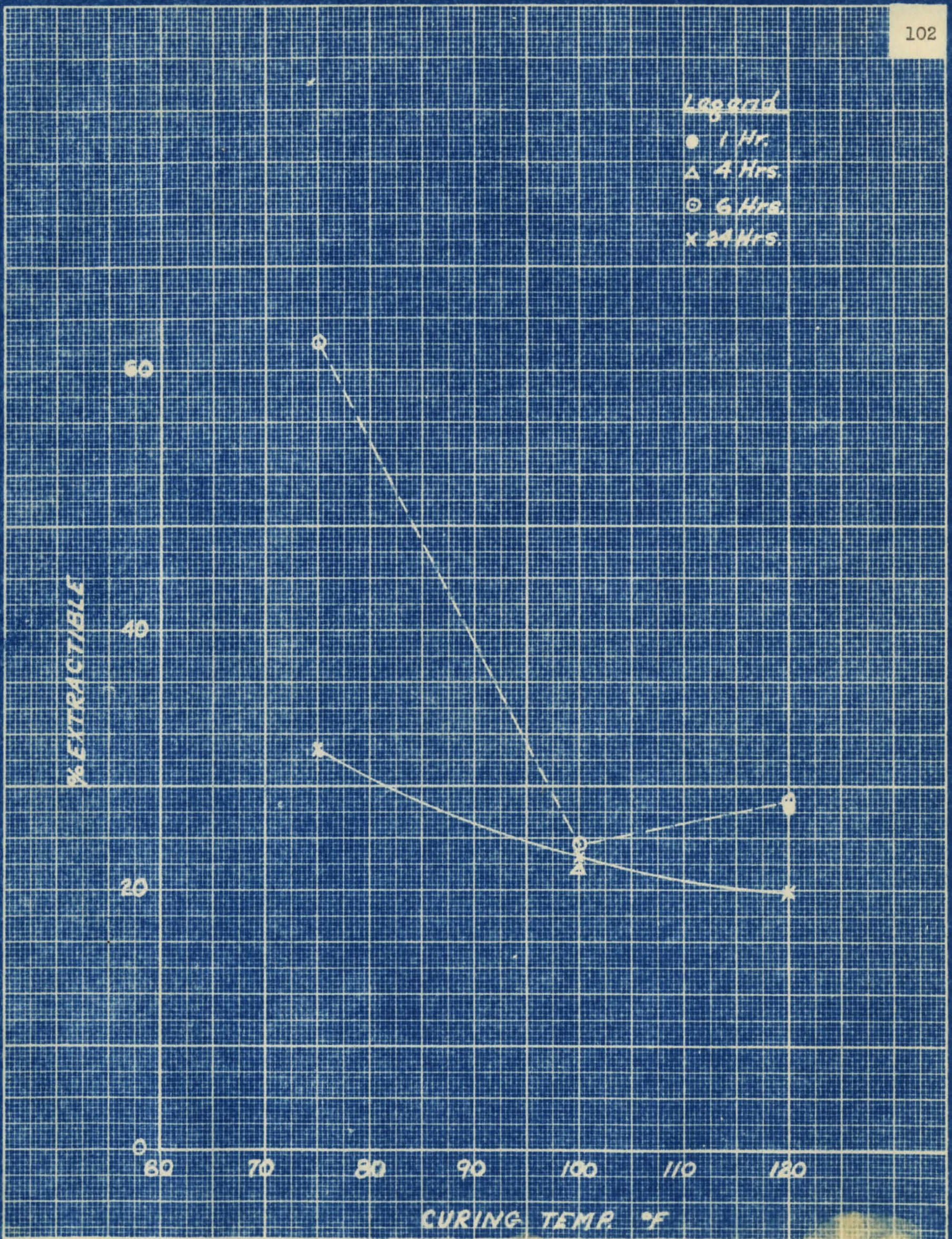

Fig. 27 Acetone Extraction of Bakelite Adhesive (XC 17613 Resin, XK 17618 Hardener) 


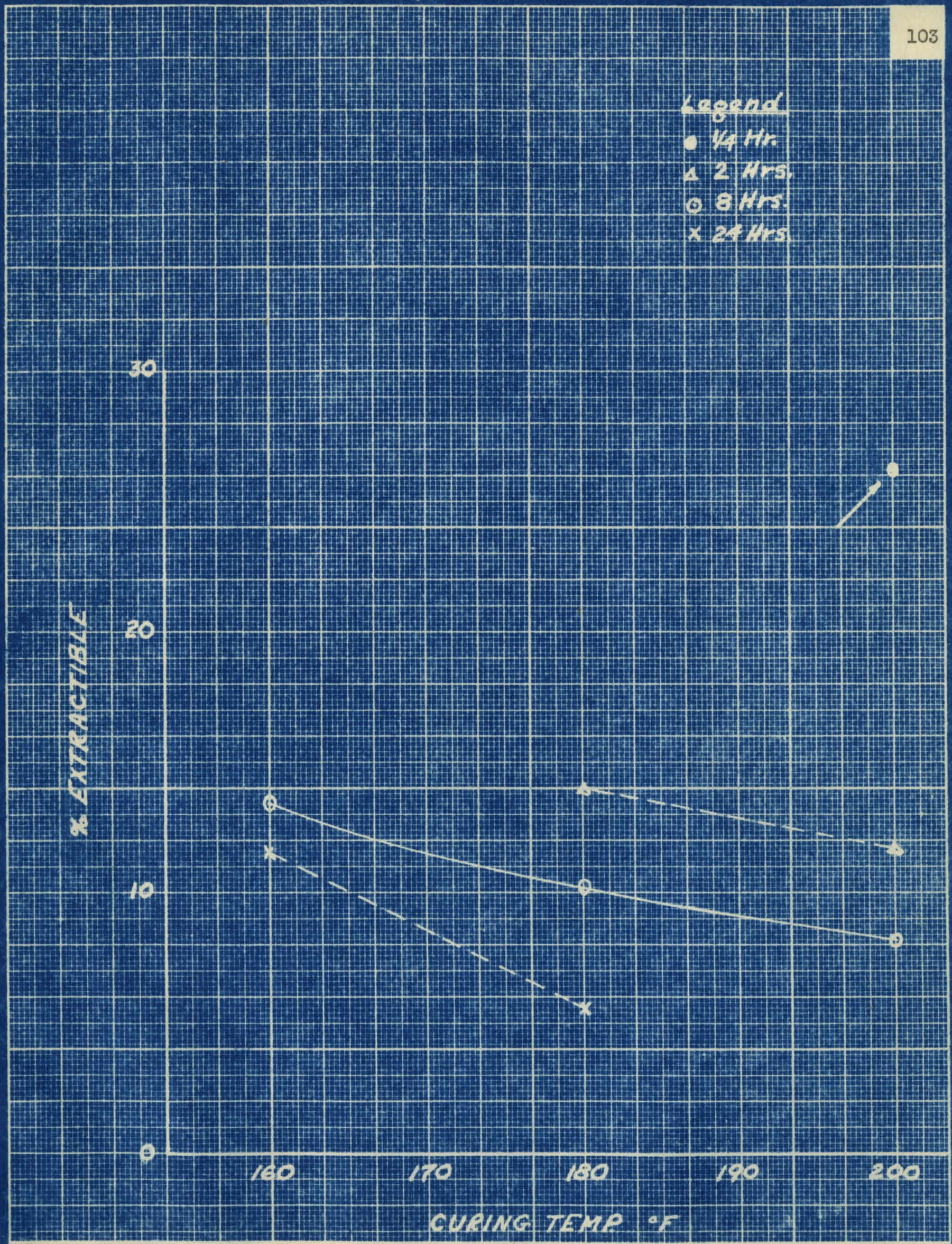




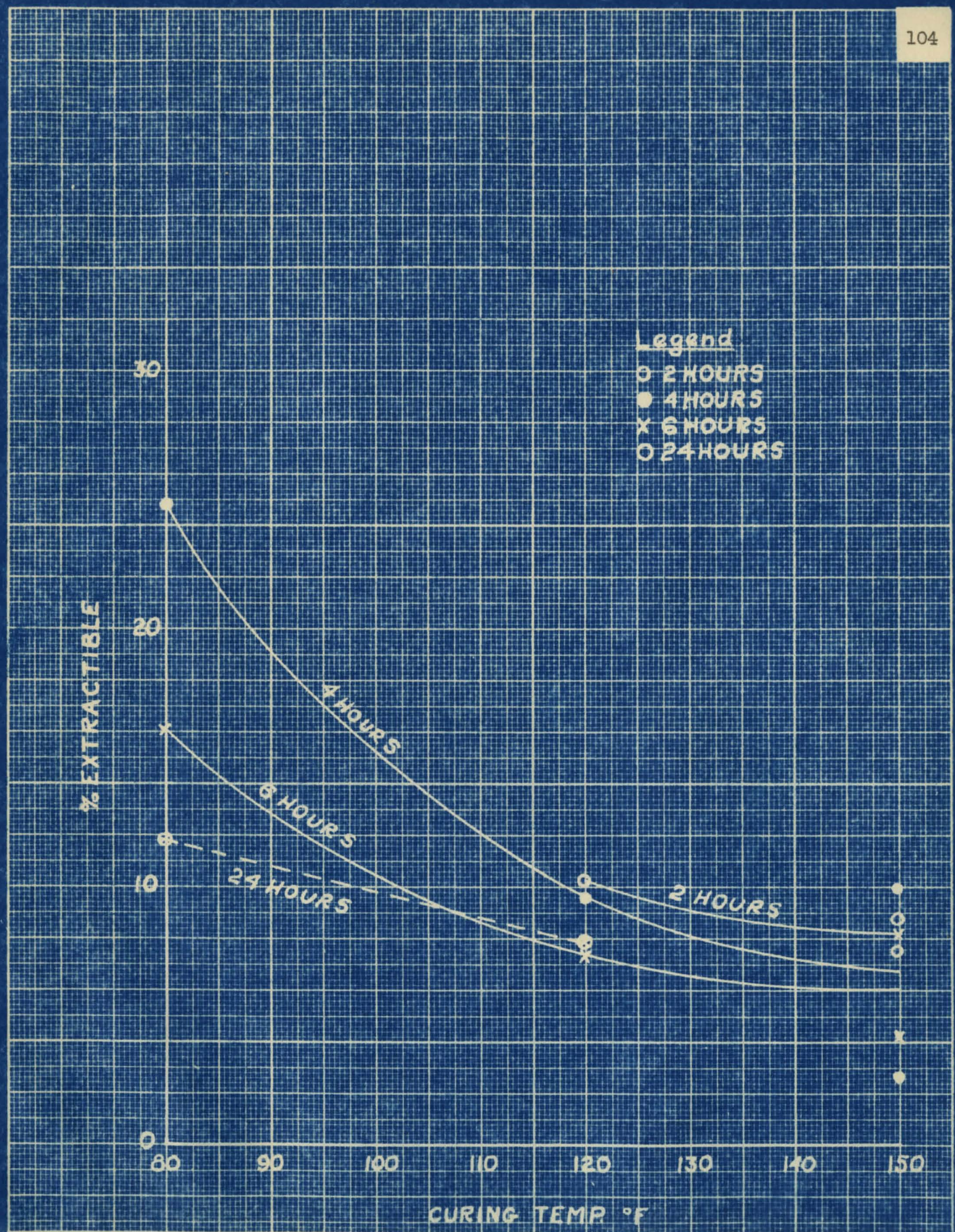

Fig. 29 Acetone Extraction of Plyophen Adhesive (\#6000 Resin, \#6001 Hardener). 


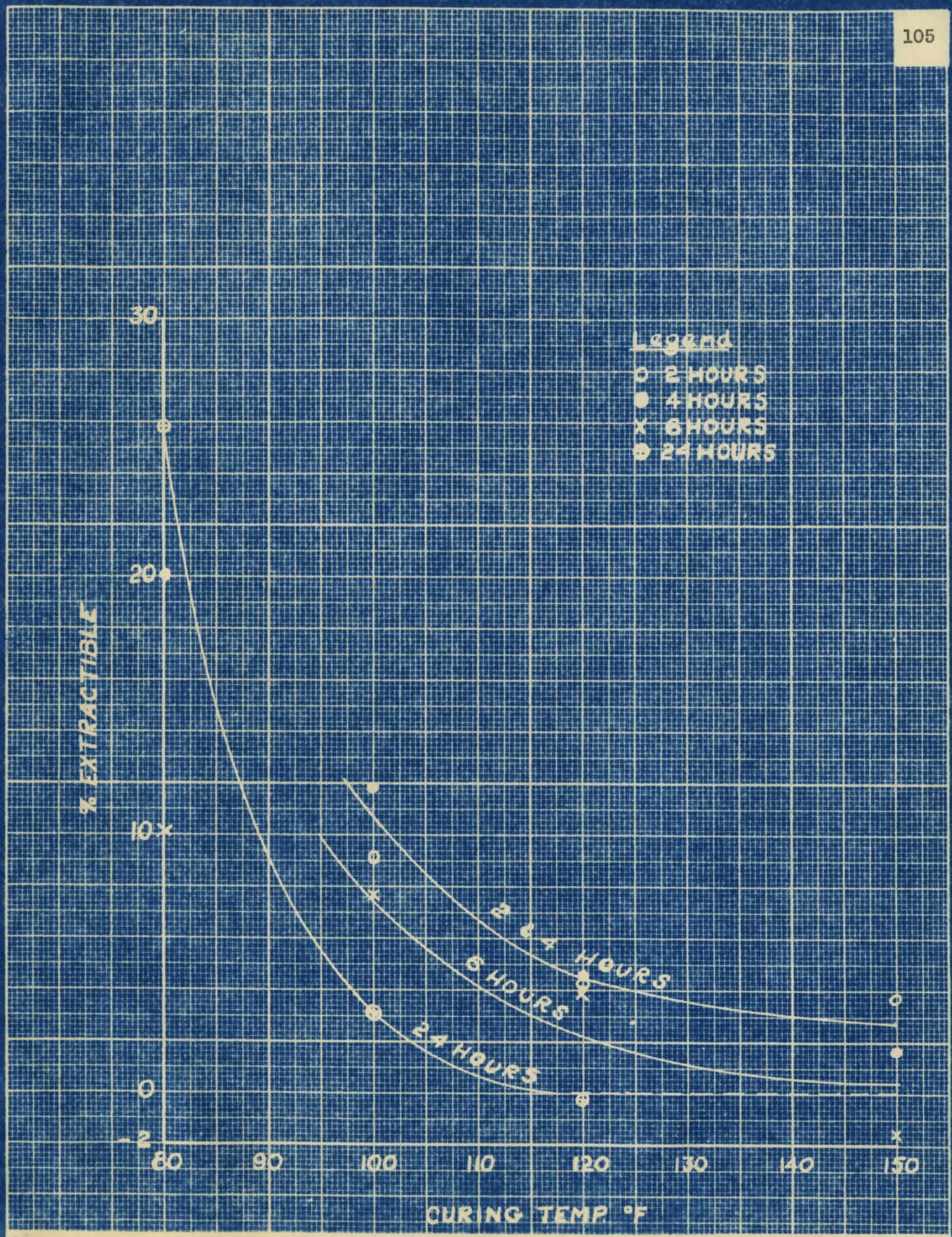

Fig. 30 Acetone Extraction of Lauxite Adhesive (PF90C Resin and Hardener). 


\section{X-PRY DIFYRACIOR PROCEDTH}

This potion is a proliminary lnvostigation of the uos of an X-ray alfernotion prooadure for deterututing the oure of rosin adhosivos.

\section{APPARATUS:}

A Hayos Diffration Dnit arploying ohnrooteristio $\mathrm{z} \alpha$ radiation from an Iron targot tube and Altored wth borylilun and manganeso acroens was ueed to X-ray the omples. A laboratory olootrio oven was need to ouro the glue filno on gless plates and hoat the ove and oollulose.

\section{MTERT 1 LS TSET:}

Cascophen LFm67, a Ifquid phonolio restn plus 3 per sont $12-10$ hardenor, a paraformidenvdo baso oatalyat. Jamufactured by The casolv Compary of Amorian.

Whito oak shaving approximatoly $1 / 32$ of an inoh in thicioness.

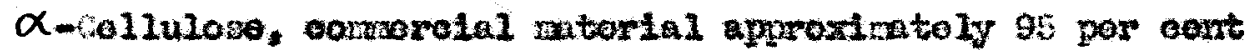

Co11w200.

EROCEDUR:

A11 radlographe excopt that of the unourec Gasoophon LF-67 (FIguro 3I) sore taicon parpandicular to tho fibor dirootion. In this cave tho athosive was put on the hoad of a nall and placod in front of

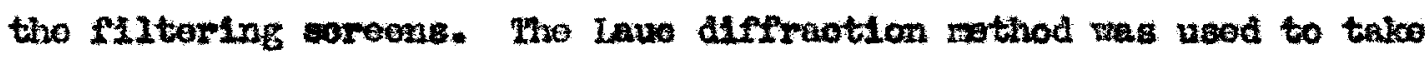
all X-rays excopt that in If gure 33 which used tho posier nothod.

The amplos $x-r a y+d$ and tho distanoe, tinc, voltage, and auparage usod an oach are given in jable XII. 


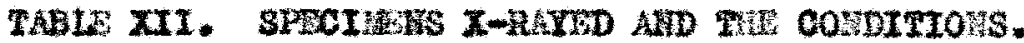

\begin{tabular}{|c|c|c|c|c|c|c|}
\hline Spoolron & Ireationt & $\begin{array}{l}\text { Dletange } \\
\text { Prom Plate } \\
\text { (on) }\end{array}$ & $\begin{array}{l}21 w 0 \\
(h \times s)\end{array}$ & $\begin{array}{l}\text { Y110m } \\
\text { Yolte }\end{array}$ & $\begin{array}{l}\text { It115- } \\
\text { aspes }\end{array}$ & $\begin{array}{l}\text { Mgure } \\
\text { No. }\end{array}$ \\
\hline In-67 plain & Unourad & 5 & 1.5 & 35 & 10 & 32 \\
\hline$L x=67-4-18$ & $n$ & ix & $*$ & $n$ & $n$ & 32 \\
\hline $14-67-1-18$ & " & Dowdar sethod & * & $n$ & $n$ & 58 \\
\hline $17-67-10$ & $\begin{array}{l}24 \text { Howne } \\
\text { et } 250 \mathrm{c} \text {. }\end{array}$ & $\mathbf{s}$ & * & * & \# & 34 \\
\hline $25-67-5-18$ & $0^{6100^{\circ}} 0$ & $*$ & * & * & $n$ & $\$ 5$ \\
\hline $25-67-\frac{18}{1}$ & $\begin{array}{l}\text { 84 Toures } \\
\text { at } 120^{\circ} \mathrm{t} \text {. }\end{array}$ & a & 1.5 & 35 & 10 & 86 \\
\hline Oak shavingo & Jnourad & 5 & 4.6 & $*$ & F & 37 \\
\hline onk Shavinge & $\begin{array}{l}24 \text { lowes } \\
\text { at } 120^{\circ}\end{array}$ & * & " & * & * & 30 \\
\hline $\begin{array}{l}\text { Oak Shatinga } \\
\text { Lim-67 and }{ }^{2}-10\end{array}$ & Tonwred & " & $n$ & $n$ & $n$ & 89 \\
\hline $\begin{array}{l}\text { oek shuringe - } \\
\text { L-67 and : }\end{array}$ & $\begin{array}{l}\text { 24 Hown: } \\
\text { at } 20^{\circ} 6\end{array}$ & 3 & 2.5 & $n$ & $n$ & 40 \\
\hline $\begin{array}{l}\text { oak shavinf - } \\
\text { m-67 and }{ }^{2}-10\end{array}$ & $\begin{array}{l}0170 \mathrm{wr} s \\
\text { at } 100^{\circ} \mathrm{c} \text {. }\end{array}$ & $n$ & $n$ & 35 & 10 & $\mathbf{M I}$ \\
\hline $\begin{array}{l}\text { Oati shaving - } \\
\text { LP-67 and } 1-18\end{array}$ & $\begin{array}{l}2 A \text { rover } \\
\text { at } 120 \mathrm{c} \text {. }\end{array}$ & 6 & 4.6 & 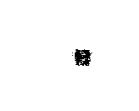 & 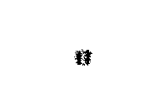 & 42 \\
\hline$\alpha-$ cellulow & Trowned & $n$ & $v$ & * & * & 45 \\
\hline$\alpha-\operatorname{col} \ln 1000$ & $\begin{array}{l}24 \text { 10tas } \\
120^{\circ} \mathrm{c} .\end{array}$ & " & * & p & $n$ & 4 \\
\hline $\begin{array}{l}\alpha-\text { callulano - } \\
\text { L-67 and } \mathrm{n}-18\end{array}$ & Bnoured & 4 & 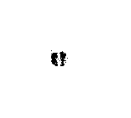 & $"$ & $n$ & 45 \\
\hline $\begin{array}{l}\alpha-\text { vellulose - } \\
\text { L-27 and } 10-10\end{array}$ & $\begin{array}{l}\text { an } \text { noux }^{3} \\
\text { at } 120^{\circ} \mathrm{C} \text {. }\end{array}$ & 5 & 4.6 & 35 & 10 & 46 \\
\hline
\end{tabular}




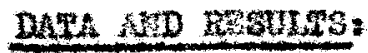

Inspeotion of Figmes 32, 34. 35. and 36 showing difrewotion pattorss of tho cascophen $17-67+2-18$ adhosivo difforent atage of

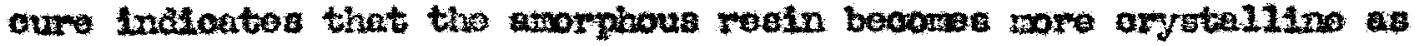

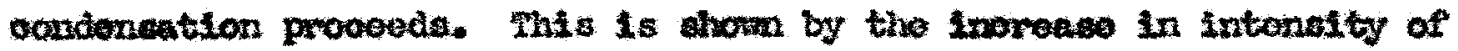
tho woond mallest rab from a goneral fogelnoss in the unourod garple (Figure 32) to a deflnod ring in the oured Pline (Figuro 36 ).

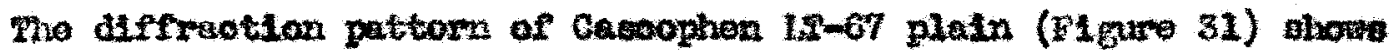
4 well defined wings, but the adaltion of tho outalyst orontes an

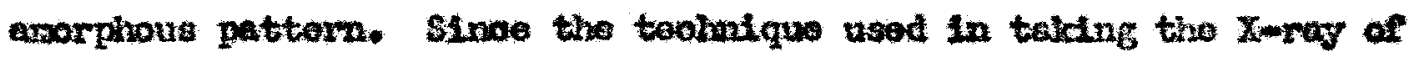
tho Casoophon Lif67 platn uffored from the others and the adcition of the oatalyat ahomed aush a dfformoe in atruoture. It nay bo

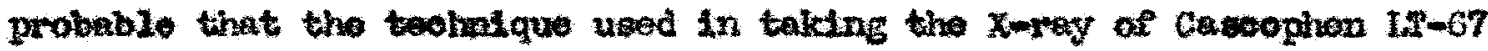

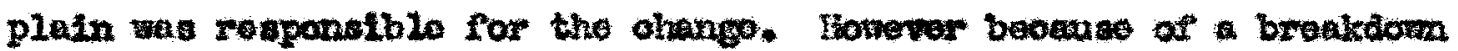
In the Afrraotion unt enother photograpt of Ca ooophon La-67 plain could not bo talken.

Oat shaving shoved four normel rings with a sllght orlantation

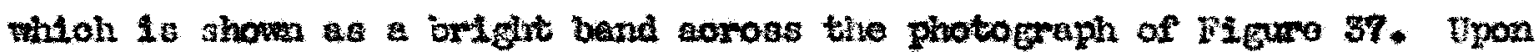
beating tho ohaviag at $120^{\circ}$. for 24 hours tho orlentatica inoroasod.

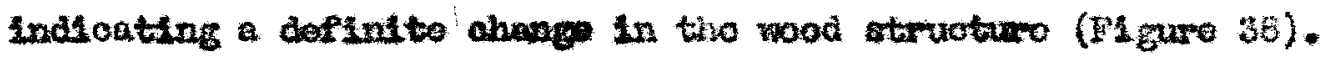

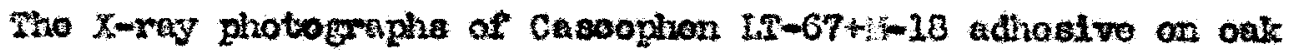

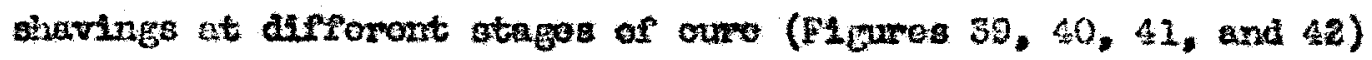
Indicate that exroet for the rotation of the orlentation band tho pattorn

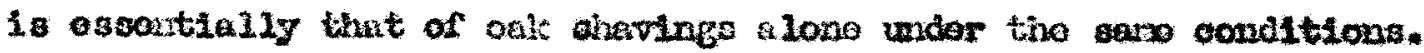
Nhus, In this case, tho ouring of the adnesive on oak is masked by the wood. 


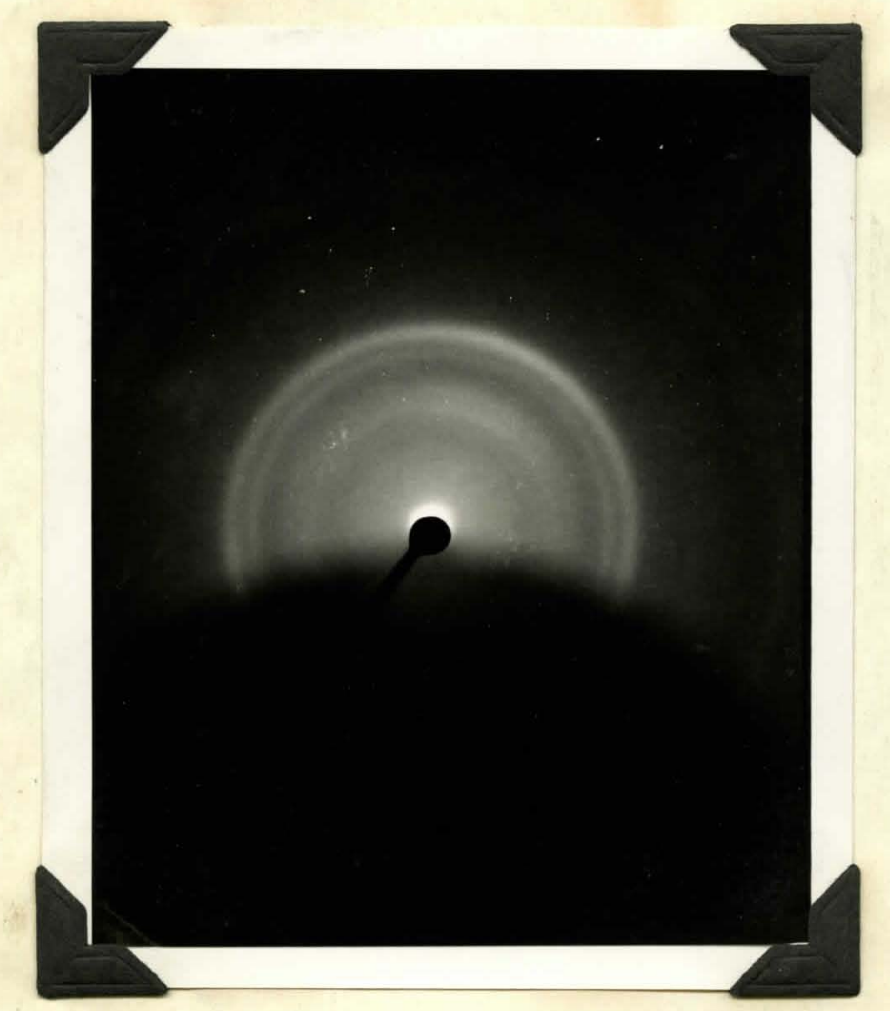

F1g. 31. X-ray DAfCruotlon Pattorn of Uneured Caseophen $1: T-67$ Adhostve.

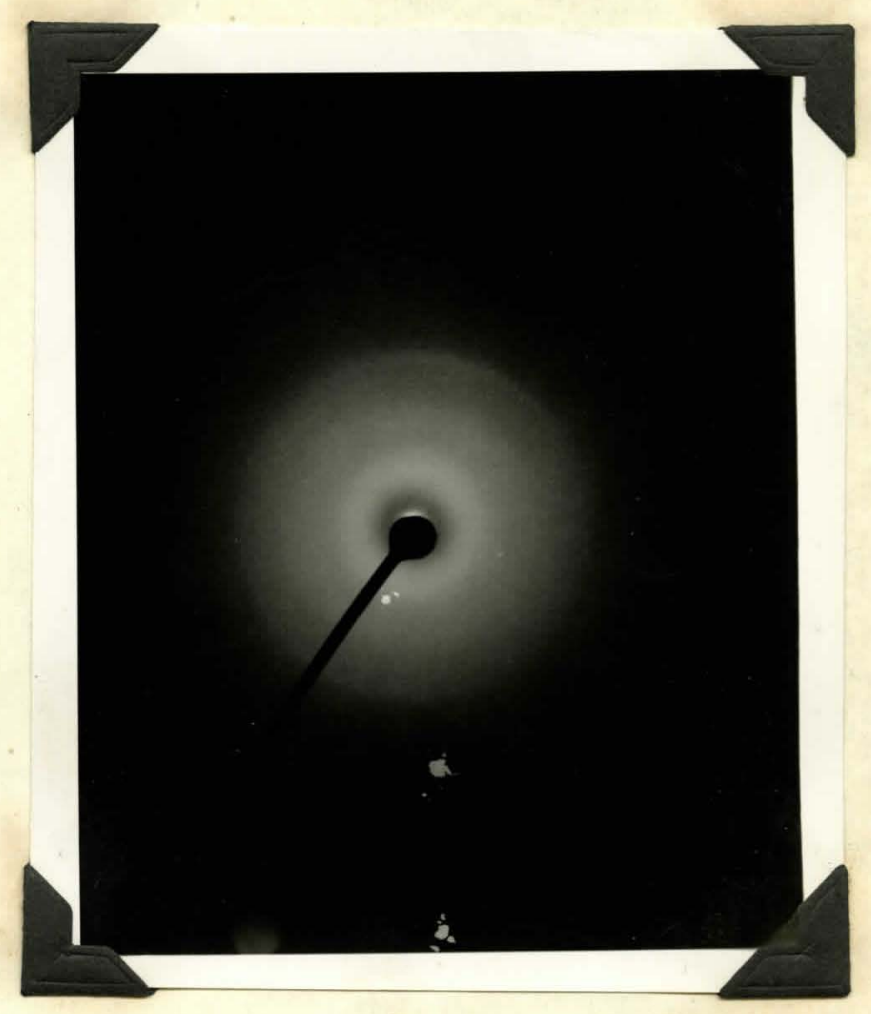

PIE. 32. X-rey DLfrection Pattern of Cascophen LT-67 is 1/-28 Adhosive (Uneured). 


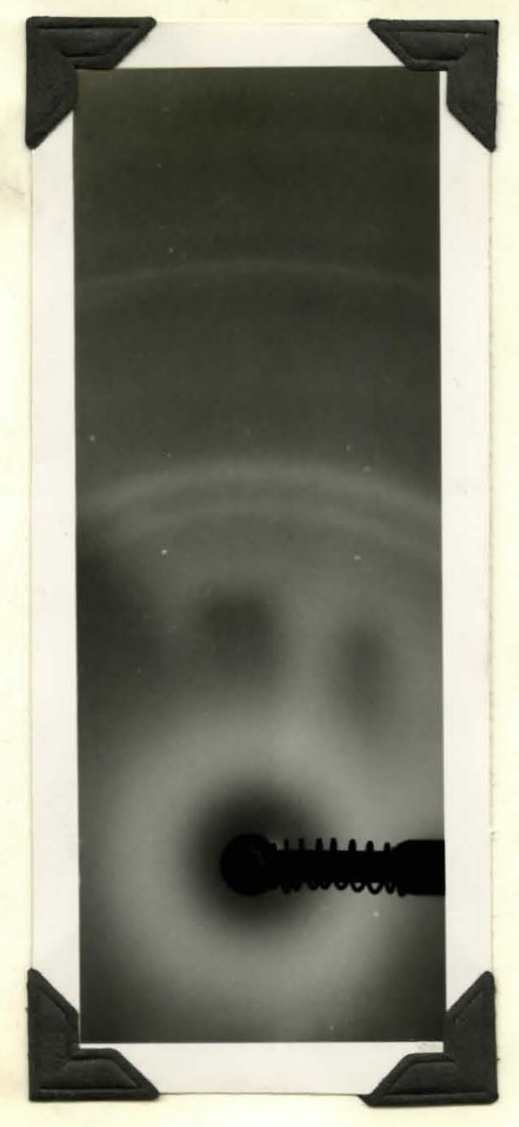

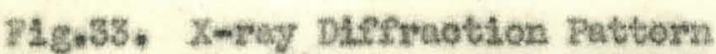
(Powdor Method) of Cavoophon $15-67$ of sim28 sdhestwo (theured).

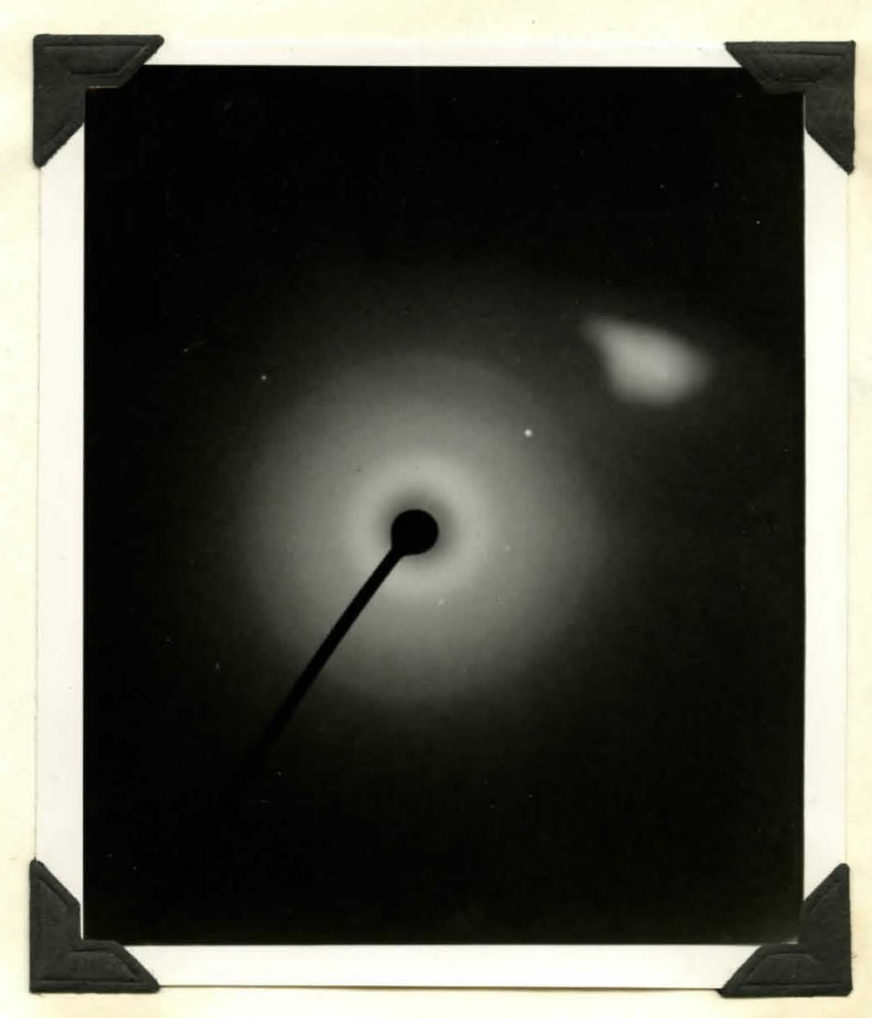

1. 3. 34. X-ray Dufreaction pabtorn of Caseophen LI-07 o il-10 Adhostve (24 Hours at $250 \mathrm{C}$ ). 


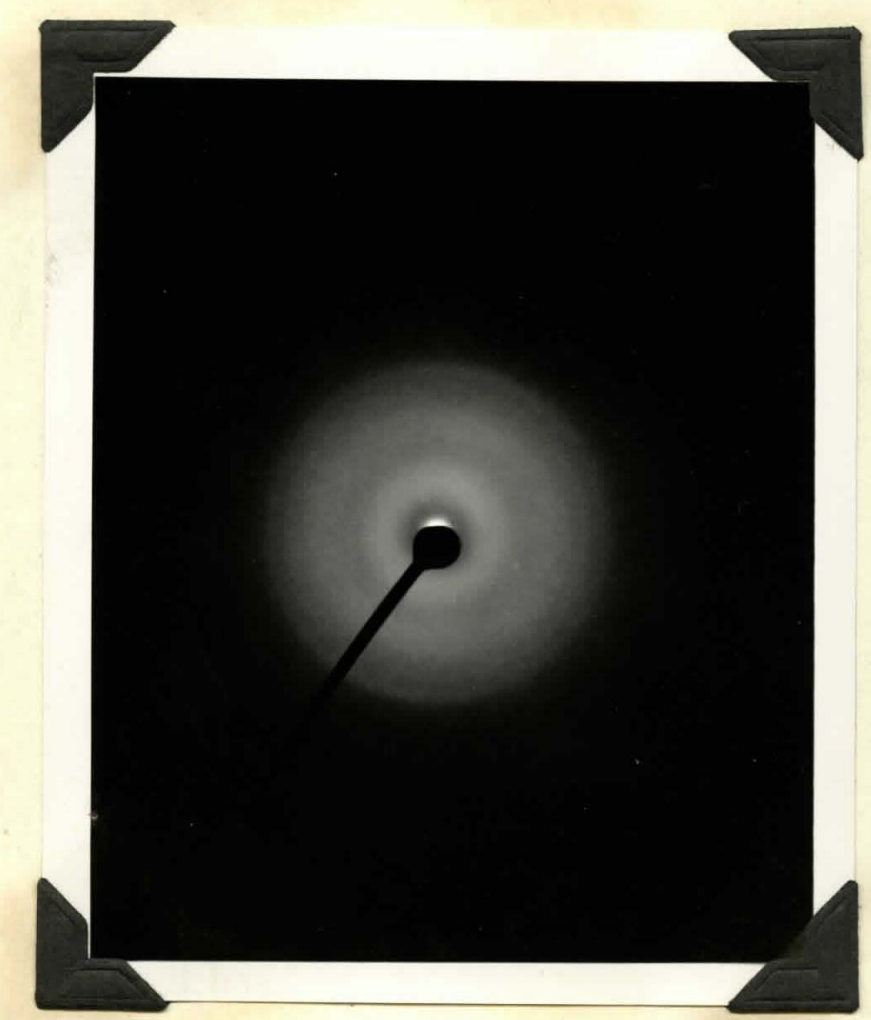

PLE* 35. X-wey DLfrraotson Patbom of Cescophen II-67 th II-18 Adnesive (6 Howes at $200^{\circ} \mathrm{co}$ ).

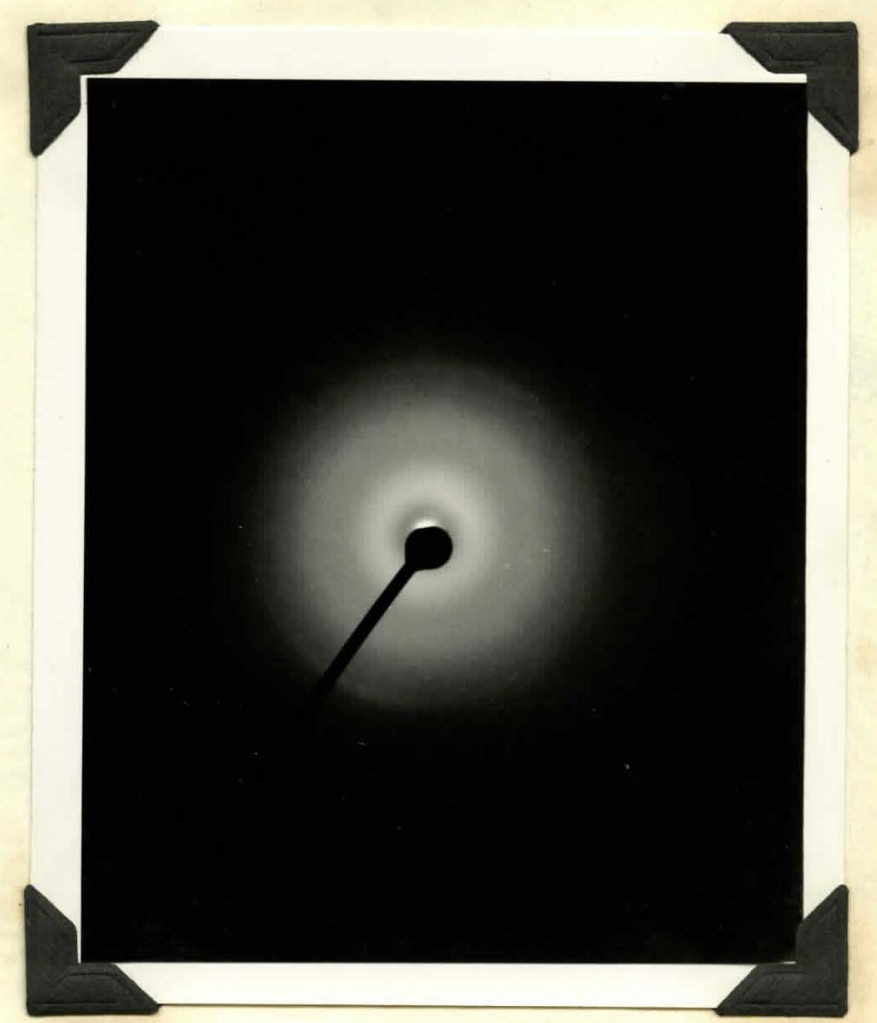

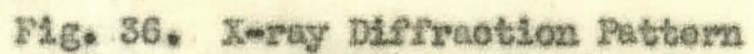
of Cascophom IT-6? is $1:-28$ Achesive (2A Rours at $220^{\circ} \mathrm{cs}$ ). 


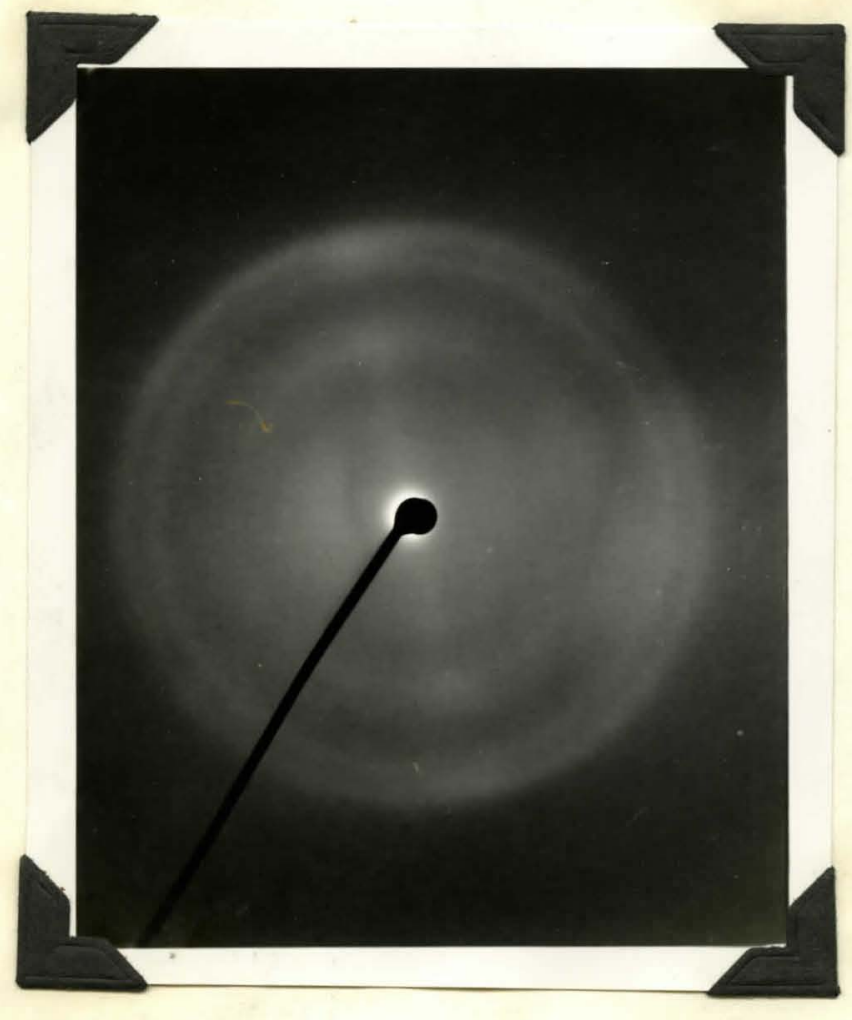

DAg. 37. X-ray DAffraothon Pattern of oals shavings.

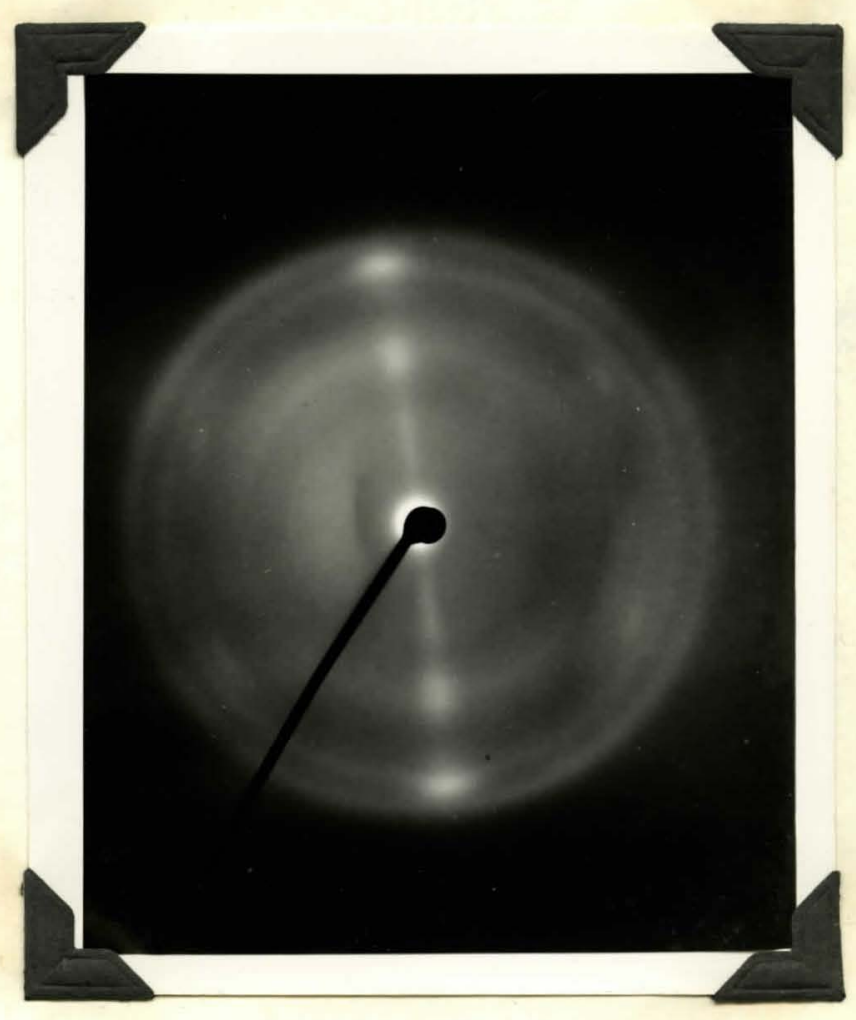

WL. 53* X-Foy DLPSraoton Patbern of Oak shavings Hoated 24 Hoves at $220^{\circ} \mathrm{c}$ 


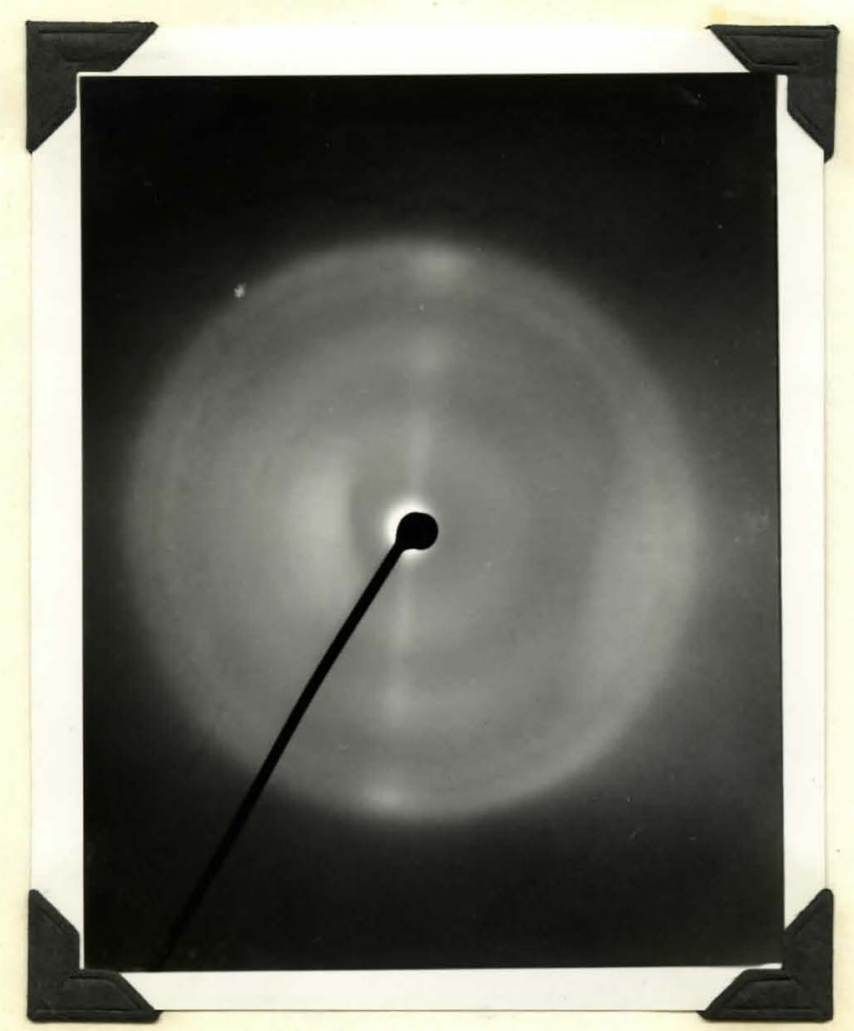

118. 59. X-ray guefraction Pattom of Oab Shavinges and Cascophen Lit-67 \& In-18 Alhosive (Unetured).

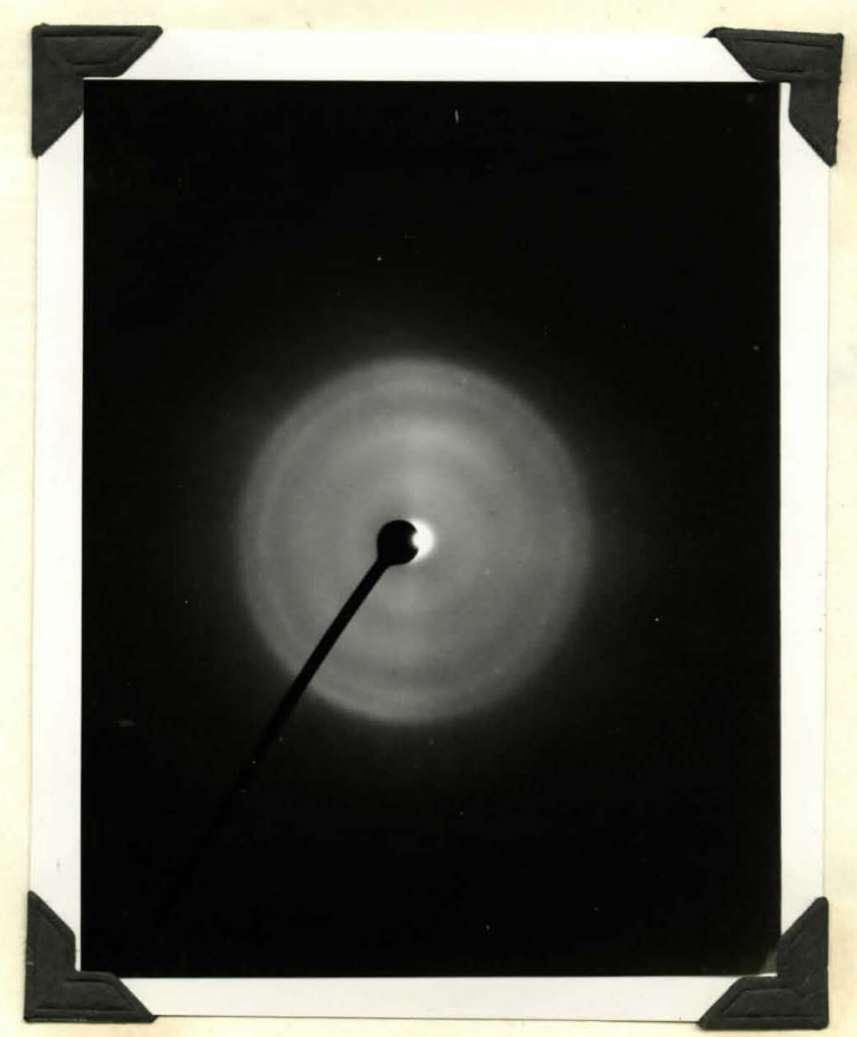

218. 40. X-ray Diffraction Ratbom of Oak Shavinge and Casoophon $35 \mathrm{~F}=67$ o is -18 Achostvo (2A Hours at $25^{\circ} \mathrm{c}$ ) 


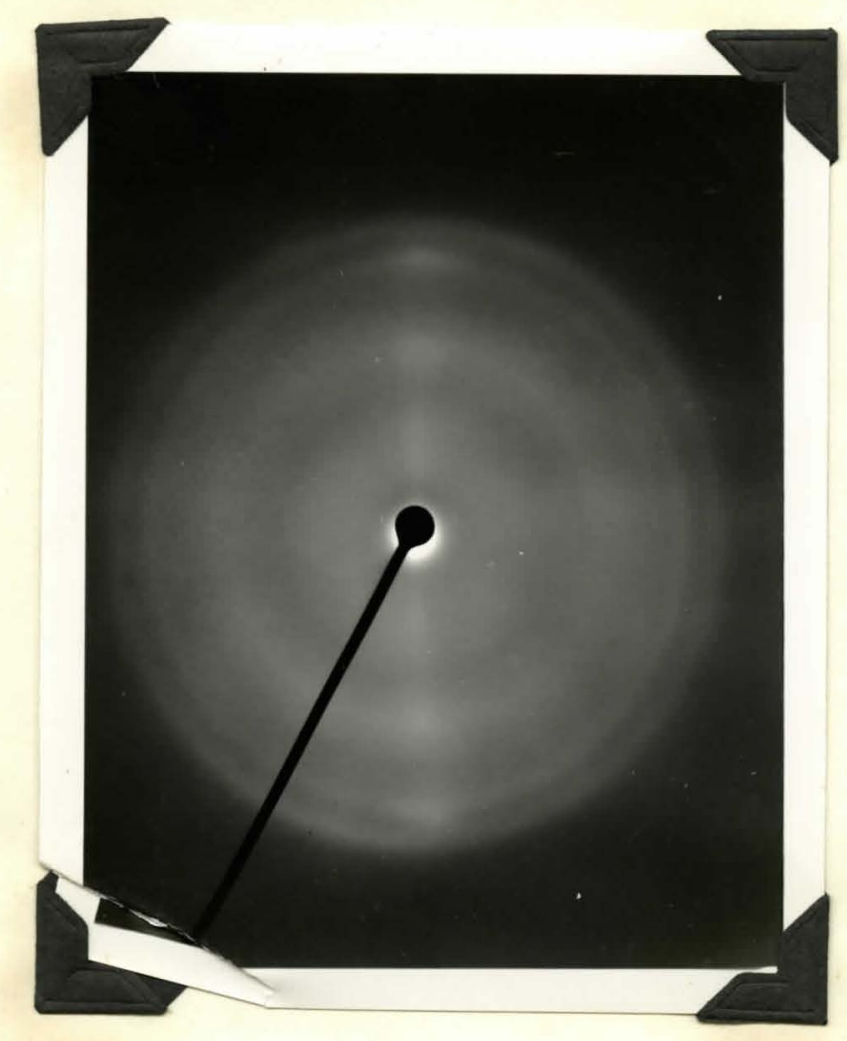

116. 42, X-1ry Difryaction Pattem of Oals Shevings and Canoophos LF-67 (4) $15-28$ Adhostve (6 Iours at $200^{\circ} \mathrm{cs}$ ).

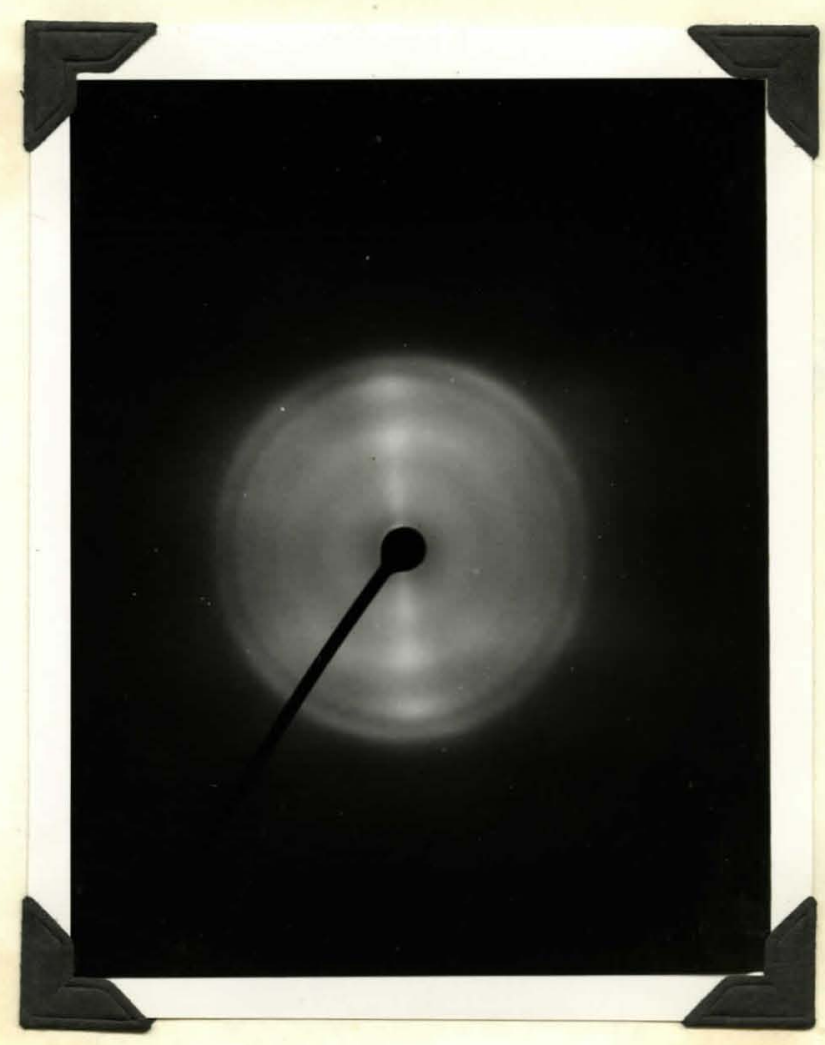

P1E. 42. Xeray DAffraction Pattorn of Onil Shavinge and Cesoophon 15m67 B ill-28 Adhestve (24 Hours at $120^{\circ} \mathrm{C}$ ). 


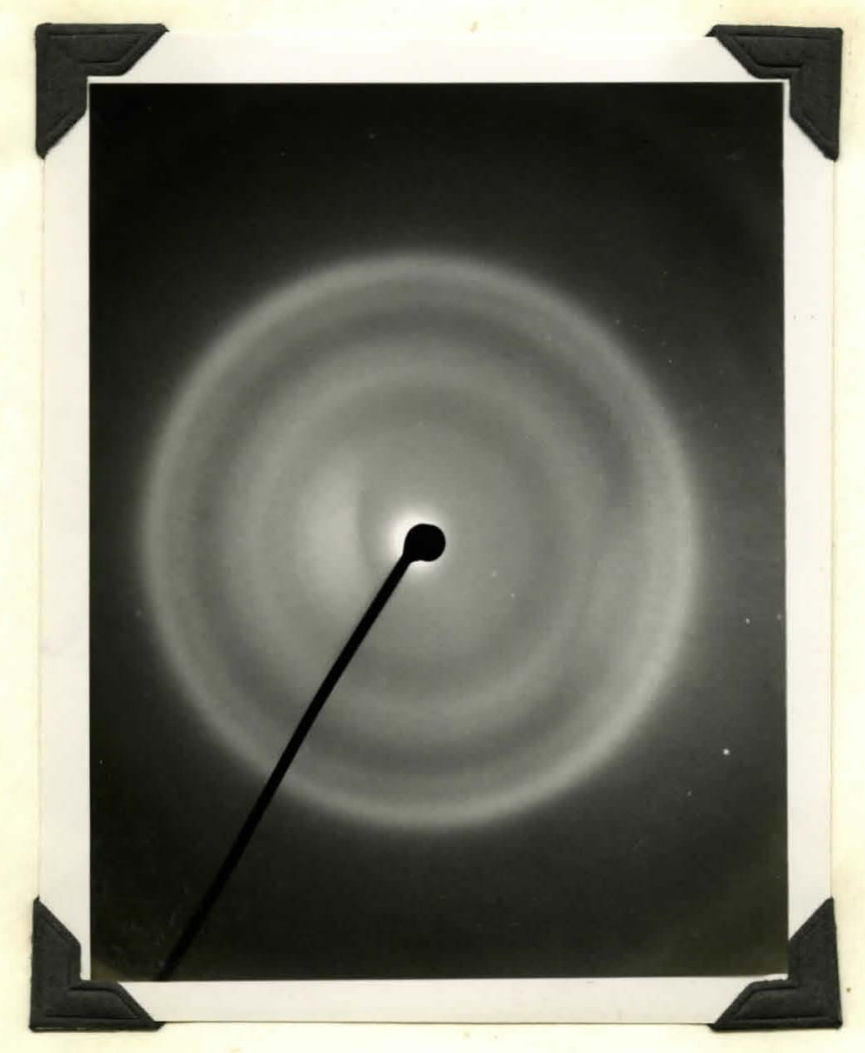

15. 43. X-ray DLfersotion Pattern of $\alpha$ - colzuloso.

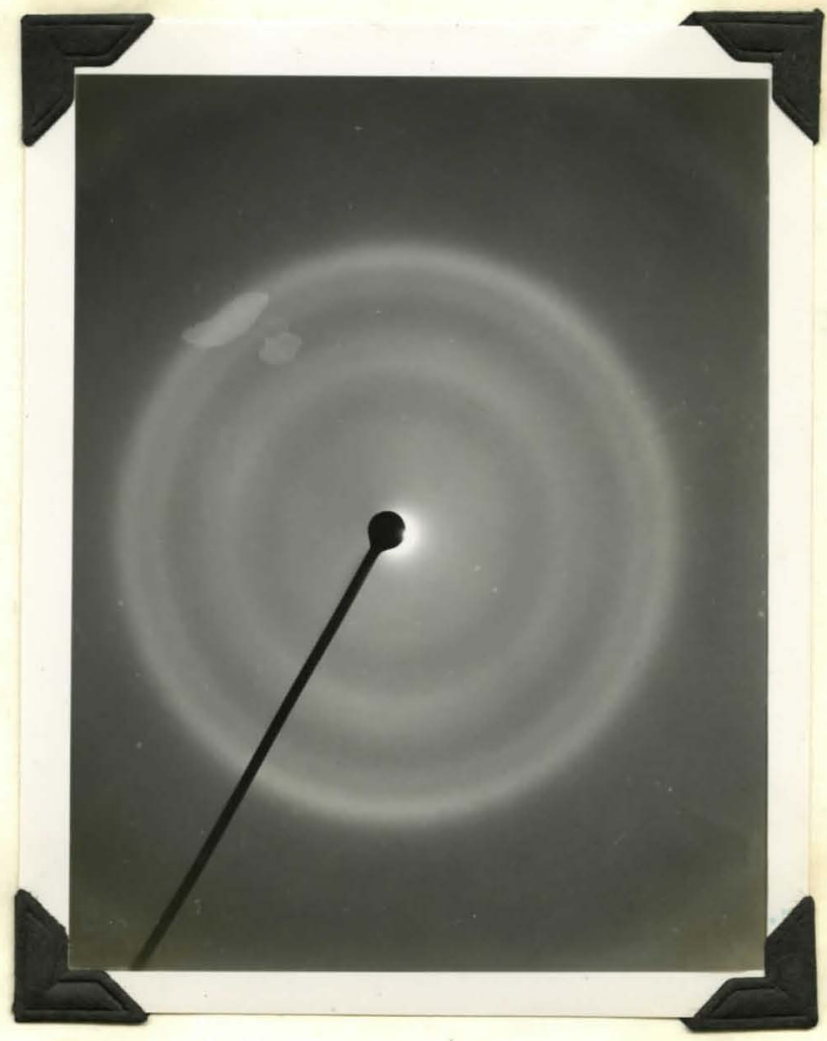

Fig. 44k X-ray Dternootlon Pettern of $\alpha$-Celiulose Hoetod 24 Hours st $220^{\circ} \mathrm{C}$. 


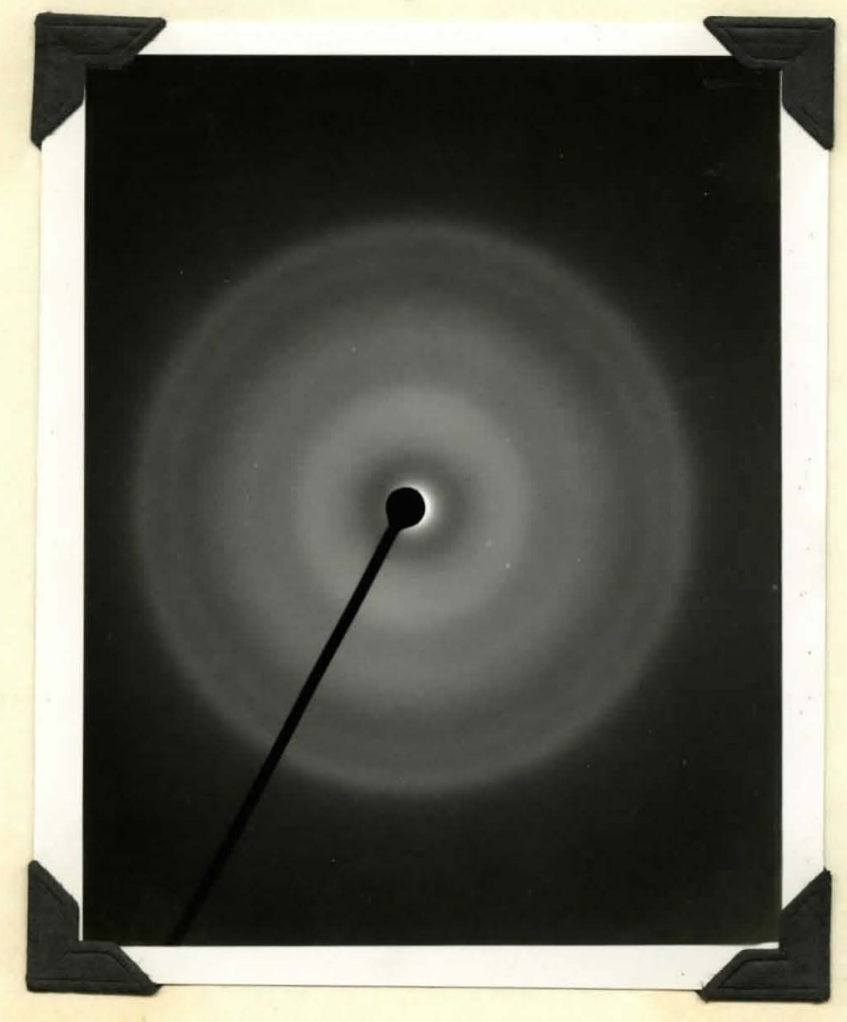

PL. 45. Xerey DAfryection Puttern of $\alpha$-Collulose and Caseophon LT67 at lim Adhostro (Jnerrod).

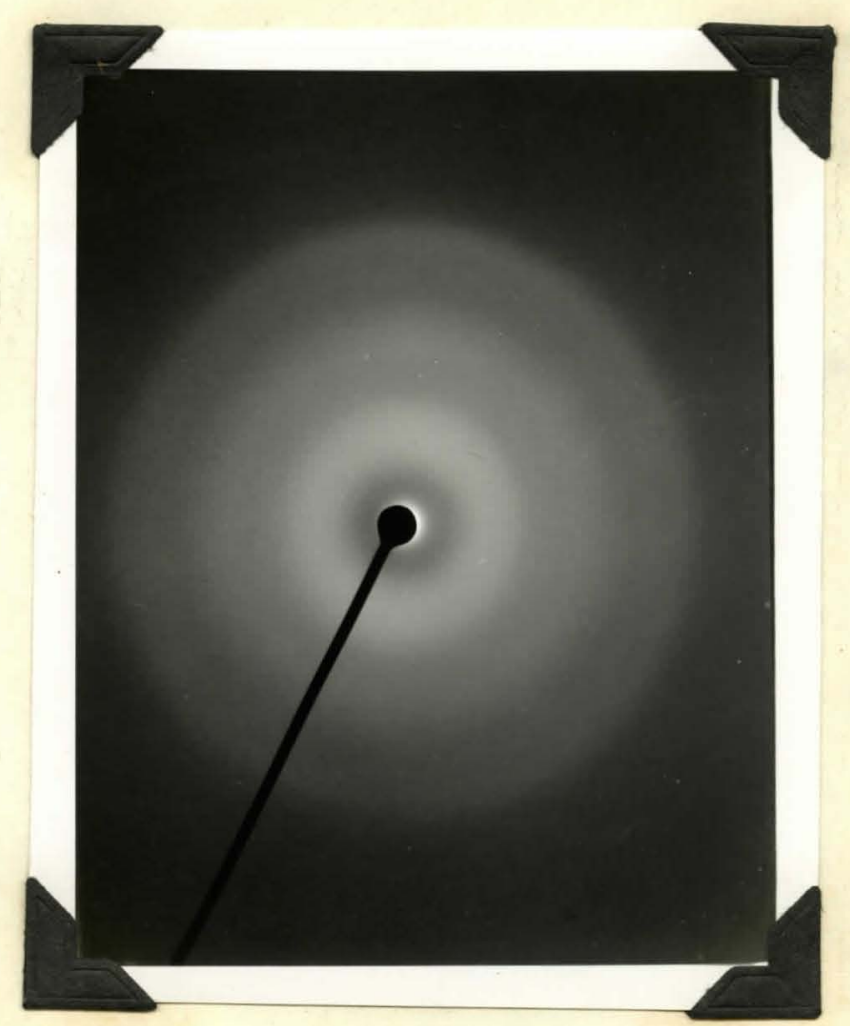

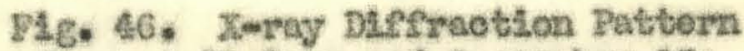
of $\alpha$-Ce13uIoso and Cascophon LF67 \& $1-28$ Adhessvo (2A Firs, at $120^{\circ} \mathrm{C}$ ). 
The plotures of $\alpha$-0023ulose (Flgures 43 and 44) show tho

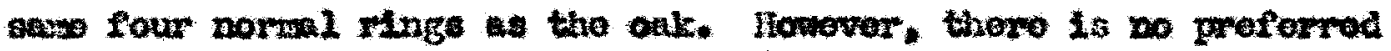
oriontation as in the wood, and thore 1 s mo indleation of any ohasge

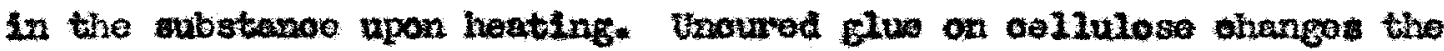

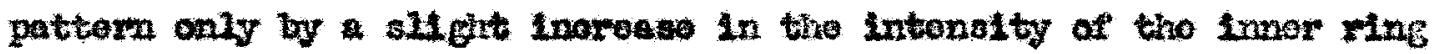
(19uro 46). Upon ourings tho intenalty of the cutar throe rings

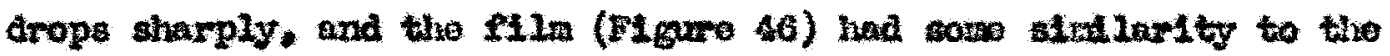

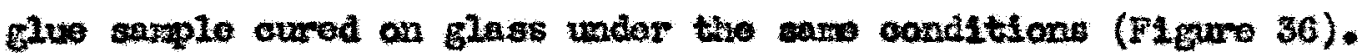
Busure:

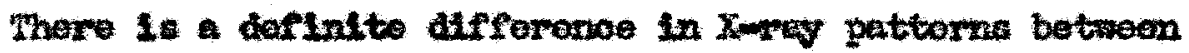
an unoured adhosiwo and adhosive oured an glass. However the results do not Indioate a cufs lotonthy sharp contragt botwaen unourod aud ourod rosins for the ues a roprodudble contral proceduro.

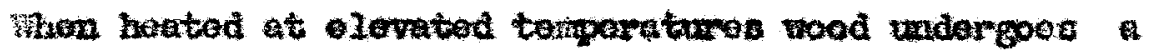

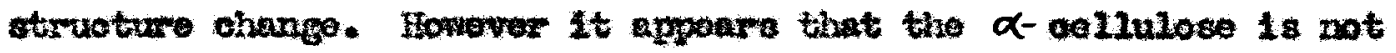
the aubtande roaponstblo for tho ohange.

The glue does not epgroctably affect the X-my pattorn of

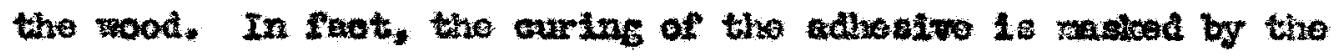
structure of the wood.

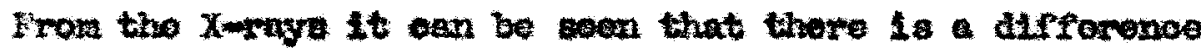

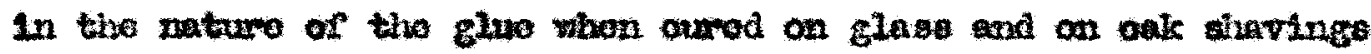
or $\alpha-0$ llulono. 


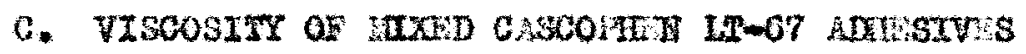

onds sootion was wiortalen to inoroaso tho pot 14 fe of Cageophon

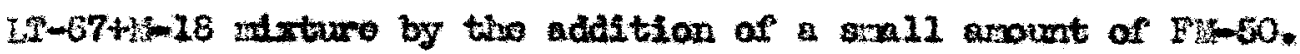

MuAnus:

The apparatus uood in thi dotormation was a 44 ford oup. a Kodal timar, tharmonoter, and standard laboratory Glasmare.

\section{MTSTIS:}

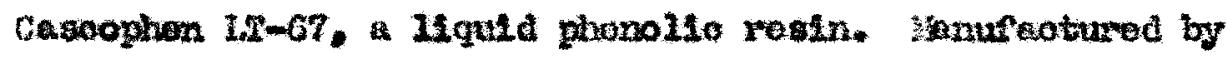
The Gaveln Conpary of Arardoa.

I-18, a porderad paraformaldehyde buso oftalyst.

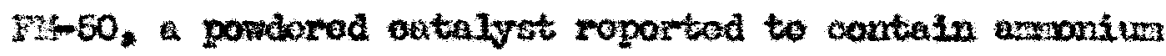
cuifuto.

Pogentre:

Sarplas approxinately $250 \mathrm{ml}$. woh woro preparod of plain

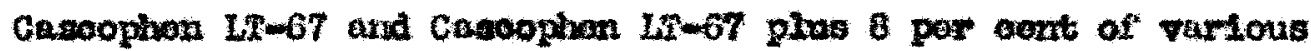
mixtures of the two otalyst. Tho per oont is baed on the roight of the pure restn. These sarples nore hold at roon temporaturo

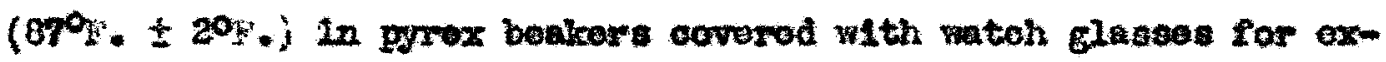
tended pertods of time while visodity toate wero mado at intorvals.

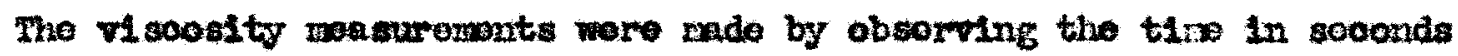
regulred for $50 \mathrm{ml}$. of glue to flow through the orffles of a standard 4 Ford Visoost oup. 
2ald XII. - VISCOSI

\begin{tabular}{|c|c|c|c|c|c|}
\hline \multicolumn{2}{|c|}{$\begin{array}{l}\text { Ln-67 } \\
\text { Plain }\end{array}$} & \multicolumn{2}{|c|}{$\begin{array}{r}2 x-57 \\
3: 01 a \\
9-80 \\
\end{array}$} & \multicolumn{2}{|c|}{ 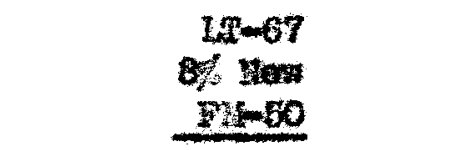 } \\
\hline $\begin{array}{l}\text { Ting of } \\
\text { Set (Exe) }\end{array}$ & $\begin{array}{l}\text { V1800sity } \\
\text { S0000nde } \\
\end{array}$ & $\begin{array}{c}\text { se of } \\
\text { Set (Exe) }\end{array}$ & $\begin{array}{r}\text { Vi soost ty } \\
\text { Seoonde" }\end{array}$ & 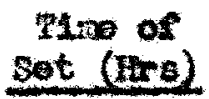 & $\begin{array}{l}\text { Viseodit } \\
\text { Sooonde }\end{array}$ \\
\hline 0 & 60 & 0.0 & 159 & 0.0 & 166 \\
\hline 46 & 305 & 0.2 & 200 & 0.5 & 178 \\
\hline 69 & 128 & 0.6 & 258 & 1.0 & 175 \\
\hline 93 & 182 & 2,0 & 241 & 17.0 & 223 \\
\hline 116 & 201 & 2.5 & 234 & 28.0 & 221 \\
\hline \multirow[t]{6}{*}{$\mathbf{1 4 2}$} & 342 & 17.0 & 243 & 60.0 & 341 \\
\hline & & 09.5 & 410 & 91,0 & 440 \\
\hline & & 92.0 & 550 & 124.0 & 616 \\
\hline & & 215.0 & 020 & 138.0 & 980 \\
\hline & & 139.0 & 1051 & 144.0 & 880 \\
\hline & & 165,0 & 1320 & 164.0 & 1462 \\
\hline
\end{tabular}

- Mim of flow for $50 \mathrm{~m}$. through Ford cup. 


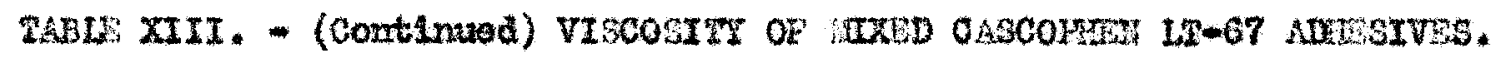

\begin{tabular}{|c|c|c|c|c|c|c|c|}
\hline \multicolumn{2}{|c|}{$\begin{array}{c}27-67 \\
a_{f}^{g}=18\end{array}$} & \multicolumn{2}{|c|}{ 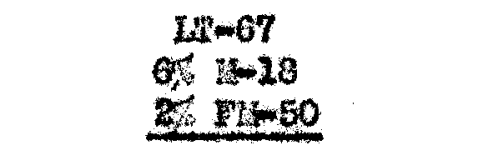 } & \multicolumn{2}{|c|}{ 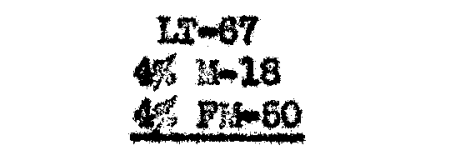 } & \multicolumn{2}{|c|}{ 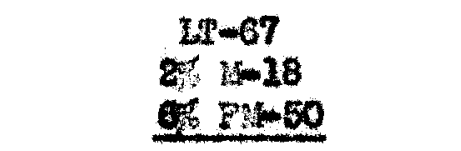 } \\
\hline $\begin{array}{c}\text { Time of } \\
\text { set (Bin) }\end{array}$ & $\begin{array}{l}\text { V1,80081ty } \\
\text { seconde* }\end{array}$ & $\begin{array}{c}\text { Thtn of } \\
\text { Set (Bar) }\end{array}$ & $\begin{array}{l}\text { V1,000sity } \\
\text { Seoonde }\end{array}$ & $\begin{array}{c}11=0 \text { of } \\
\text { sot }(\mathrm{Bre})\end{array}$ & $\begin{array}{l}\text { Visooul by } \\
\text { Secondd }\end{array}$ & $\begin{array}{l}\text { Thioe of } \\
\text { set (ifrs) }\end{array}$ & $\begin{array}{l}\text { V1,0008ity ty } \\
\text { 8000nete }\end{array}$ \\
\hline 0.0 & 104 & 0.0 & 110 & 0.0 & 207 & 0.0 & 269 \\
\hline 0.6 & 325 & 0.5 & 100 & 0.5 & 312 & 0.25 & 335 \\
\hline 2.0 & 235 & 0.75 & 225 & 1.0 & 360 & 1.25 & 582 \\
\hline 2.5 & 417 & 3.0 & 821 & 1.26 & 392 & 10.5 & 900 \\
\hline 1.8 & 2024 & 1.5 & 622 & 1.6 & 454 & 25.0 & 960 \\
\hline & & 2.0 & 1350 & 8.75 & 1321 & & \\
\hline
\end{tabular}

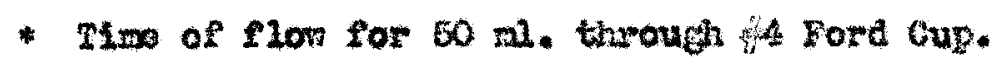


DATA AD HEUTE:

Trable XII and FIfares 47 and 48 prosent the viseosity data of the varlous mixturos. The data aro alno progentod of an PI-60 Whah hed been stored ono yoar at roon tezperature.

It can boen that tho pot $14 f 0$ of the adhestve is groatly

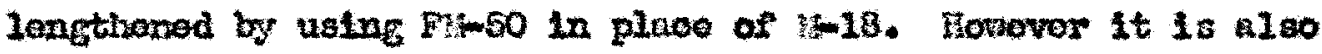
ovident that up to an hour and a half, and a visoosity roadinf of

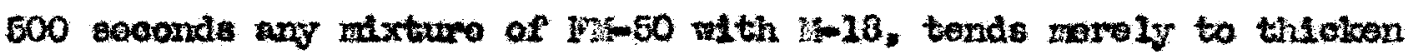

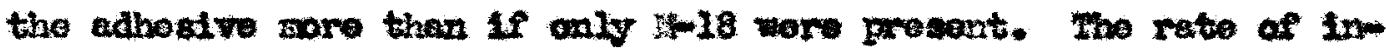
aroase In Fiscostby abovo this point is oonglderably blowed by tho prosenoo of EIS-50. llowewor it has been untionod proviously that 400 seoonds 1 the doatrable upper lint of usablo viscositios; therofore it is ovidont that the prosenoe of $12-50$ with 1 - 20 aan only be hamelu. 


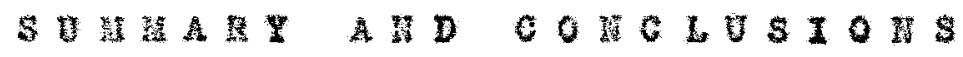


1. Acotono Extration of Gluo Filws.

The rooomondod ouring oonditions of the adhosives are as followa:

$$
\begin{aligned}
& \text { Durez } 12688+12369 \\
& 100 \%,-24 \text { hours } \\
& 1200^{2} \text {. - } 6 \text { hours } \\
& \text { Daleolite } \mathrm{xC}+17613-x \mathrm{x}+27618 \\
& 100^{\circ} \text {. } 4 \text { houms } \\
& 1200 \mathrm{~F} .1 \text { how } \\
& \text { Daise 14to } x 0-17640+x<-17546 \\
& 160^{\circ} \text {. * s hours } \\
& 100^{\circ} \mathrm{F} \text { - } 2 \text { hours }
\end{aligned}
$$

Plyophon $0000+6001$

$$
\begin{aligned}
& 120^{\circ} \mathrm{F}-6 \text { hours } \\
& 150 \% \mathrm{~F}-2 \text { to } 4 \text { hours }
\end{aligned}
$$

Caseophon $13-210+12+80$

$$
\begin{aligned}
& 1200 \% \text { - } 24 \text { hours } \\
& 150^{\circ} \text {. - hours }
\end{aligned}
$$

Ponacolite os-1124

$$
\begin{aligned}
& 1200_{*}-24 \text { hours } \\
& 2600_{\text {. }}-4 \text { hours }
\end{aligned}
$$

Land to $\mathrm{PF}-90 \mathrm{C}$

$$
\begin{aligned}
& 100^{\circ} \mathrm{F} \text { - } 24 \text { houre } \\
& 120^{\circ} \mathrm{F}-6 \text { hours } \\
& 150^{\circ} \mathrm{F} \text { - } 4 \text { hours }
\end{aligned}
$$


2. X-ray Difraction Procedure.

Tho romults of glues curod on glabs indloate a chango in struoture so cure prodeds. Howevor the X-roy pattorns do not show sureselently sharg contwast botweon unewred and carod resins to bo used as a control prooodure in place of the acotone extration method.

The diffraction pattarne of the glvo on oak and $\alpha$-collulobo

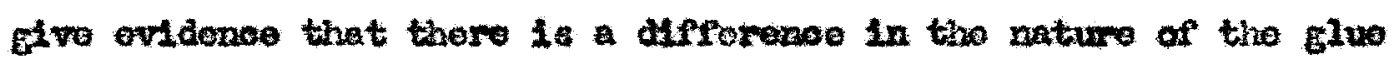
when ourod on flase and an wood.

The ouring of the adhostros on wood Is masked in the $x$-roy pattorns by the wood. Therofore it soens frow thoec prellnimary teste that the wothod of teating the cure of gluod wooden spoctmons by X-my diffraotion is of no uso. Howevor the data aro too mongor to alspose of the procodure without soro furthor stady.

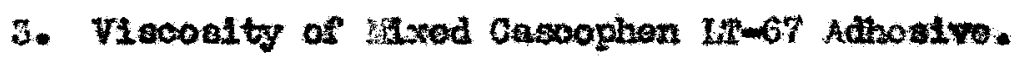

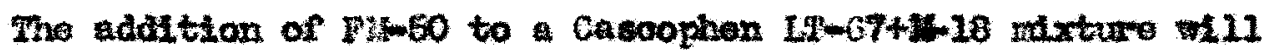
not inorease the pot 14 fo but 1211 derlutely shorten it. 


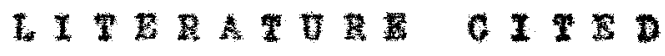




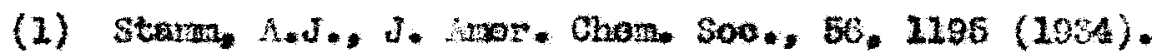

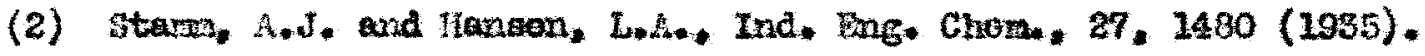

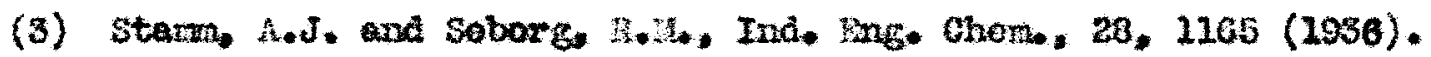

(4) Starm, A.d. and soborg, R. H., Trank, A. I. Ch. E., 37, 385 (1041).

(5) Sorlinor, J.F.\%, chon, Ind., 54, 680 (1944).

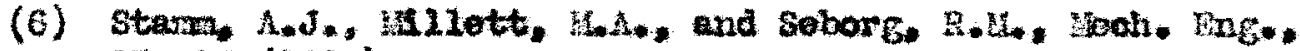
67. $25(1945)$.

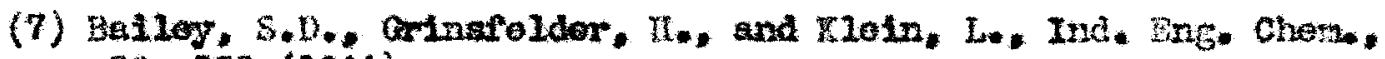
$36.252(1044)$

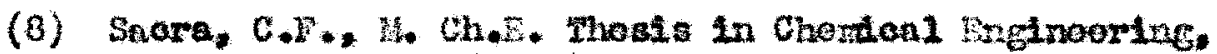
U. of Louisvillo (1944).

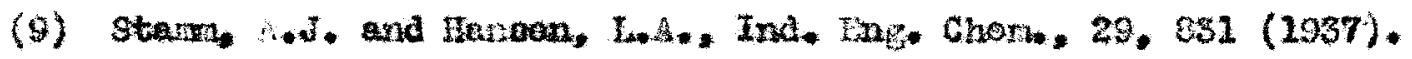

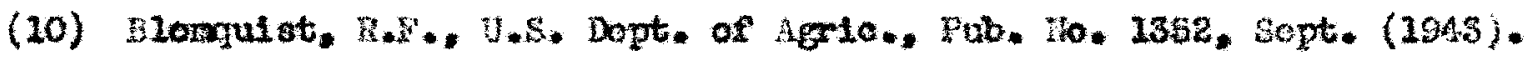

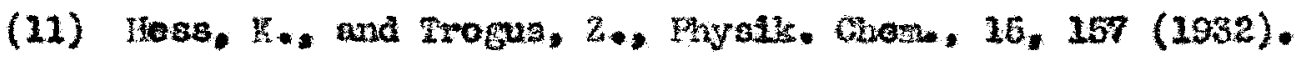

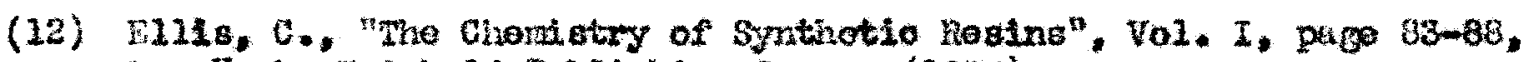

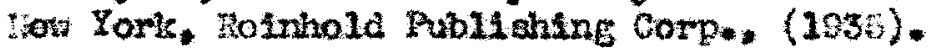




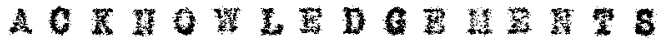


The author wishes to acknoviodge the kind abstetanoe and heIpful guldanoe of Dr. G.C. WL112ms who difreotod this rovoarch.

Iit alvo withes to exprose his approetation to Camblo 3ros. whose fellowainp in the Difision of Industrial Rosoaroh tado thi imeothgtion possiblo and to thass. C.D. Dosktos and flarold zoser who ropresontod Canble Bros. and those advi eo and oplnione havo beon axwoouingly holpful. 
Otto Joseph ralleti, Jr. born in loulevillo. Eextucky, on July 15, 1923, tho son of otto J. Hngola palawo inlots. Ito rocelvod his prirary and sogondary oducation from St. Franols of Aosiol and St. Xavior IIgh sehool roapottivoly.

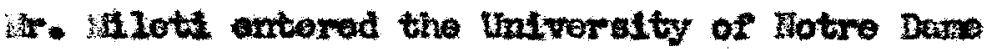
In septenter. 1941. and recelved the degroo of Dachelor of Beienoe in Chombal inglnooring in Jumo. 104 .

He vas awardod alvislon of Industrial Revoaroh followaklp at tho tonivarsty of Louidn1le in July, 194. and rocelvod tho degroo of 3 astor of Chomenl Inglnoering in ootaber. 1940.

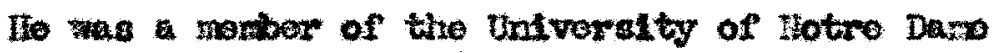
Student Ghapter of tho Aromioan Institute of Chomitoal Snglnoering and is now a jumior of the sontor organization. 